\title{
$S R O--819-25$
}

\author{
University of Georgia's \\ Savannah River Ecology Laboratory \\ Annual Technical Progress Report \\ of Ecological Research
}

Period Ending July 31, 1994 


\section{DISCLAIMER}

This report was prepared as an account of work sponsored by an agency of the United States Government. Neither the United States Government nor any agency thereof, nor any of their employees, make any warranty, express or implied, or assumes any legal liability or responsibility for the accuracy, completeness, or usefulness of any information, apparatus, product, or process disclosed, or represents that its use would not infringe privately owned rights. Reference herein to any specific commercial product, process, or service by trade name, trademark, manufacturer, or otherwise does not necessarily constitute or imply its endorsement, recommendation, or favoring by the United States Government or any agency thereof. The views and opinions of authors expressed herein do not necessarily state or reflect those of the United States Government or any agency thereof. 


\section{DISCLAIMER}

Portions of this document may be illegible in electronic image products. Images are produced from the best available original document. 


\title{
SAVANNAH RIVER ECOLOGY LABORATORY
}

\section{ANNUAL TECHNICAL PROGRESS REPORT}

\author{
$\mathrm{OF}$
}

\author{
ECOLOGICAL RESEARCH
}

SUPPORTED UNDER CONTRACT

DE-AC09-76SR00-819

BETWEEN THE UNIVERSITY OF GEORGIA

AND THE U.S. DEPARTMENT OF ENERGY

FOR THE PERIOD ENDING

JULY 31, 1994

Michael H. Smith, Director 
This report is provided for information only and is not to be considered formally published literature. We request that no citations be made of information contained herein without express written consent of the investigator.

\section{DISCLAIMER}

This report was prepared as an account of work sponsored by an agency of the United States Government. Neither the United States Government nor any agency thereof, nor any of their employees, makes any warranty, express or implied, or assumes any legal liability or responsibility for the accuracy, completeness, or usefulness of any information, apparatus, product, or process disclosed, or represents that its use would not infringe privately owned rights. Reference herein to any specific commercial product, process, or service by trade name, trademark, manufacturer, or otherwise does not necessarily constitute or imply its endorsement, recommendation, or favoring by the United States Government or any agency thereof. The views and opinions of authors expressed herein do not necessarily state or reflect those of the United States Government or any agency thereof. 


\section{TABLE OF CONTENTS}

I. OVERVIEW OF RESEARCH PROGRAMS AND PROGRAM COMPONENTS . . . . . 3

A. Environmental Operations Support $\ldots \ldots \ldots \ldots \ldots \ldots \ldots \ldots \ldots \ldots \ldots$

A.1. SRS Impacted Wetlands $\ldots \ldots \ldots \ldots \ldots \ldots \ldots \ldots \ldots \ldots \ldots \ldots$

A.2. SRS Streams .............................. 6

A.3. Trace Organic Compounds $\ldots \ldots \ldots \ldots \ldots \ldots \ldots \ldots \ldots \ldots \ldots$

A.4. Radioecology ........................... 9

A.5. Database Synthesis . . . . . . . . . . . . . . . . . 13

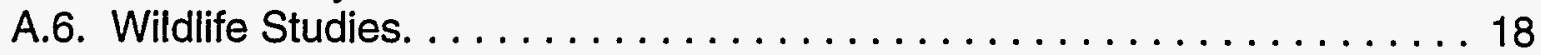

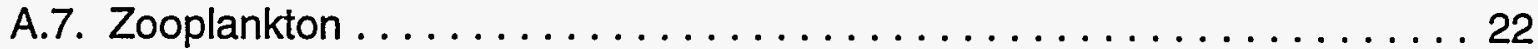

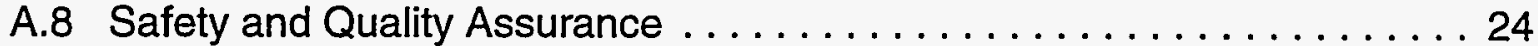

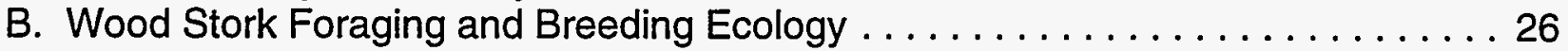

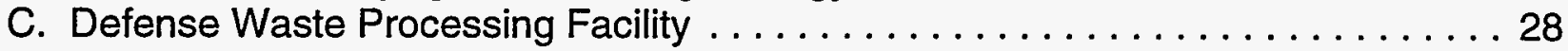

D. Environmental Risk Assessment . . . . . . . . . . . . . . . . . . . . 30

D.1. Endangered Species .......................... 31

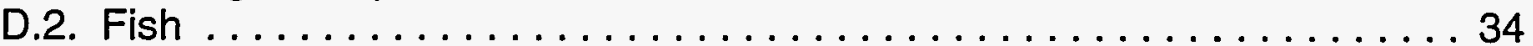

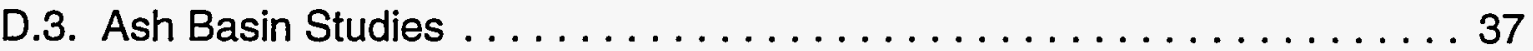

E. Ecosystem Alteration by Chemical Pollutants $\ldots \ldots \ldots \ldots \ldots \ldots \ldots \ldots \ldots$

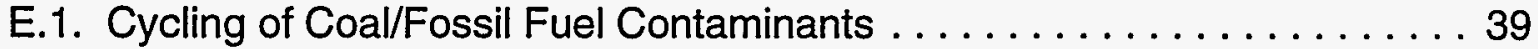

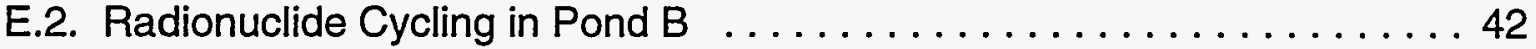

E.3. Soil/Sediment Remediation ........................... 44

E.4. Environmental Geochemistry and Toxicology of Uranium . . . . . . . 45

F. Wetland Systems . . . . . . . . . . . . . . . . . . . . 48

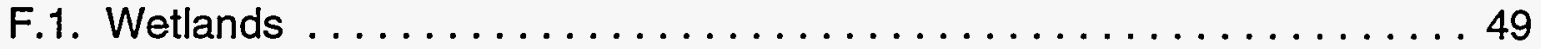

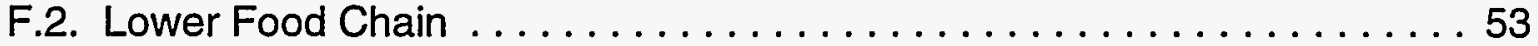

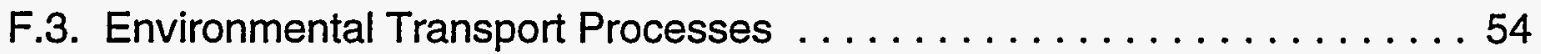

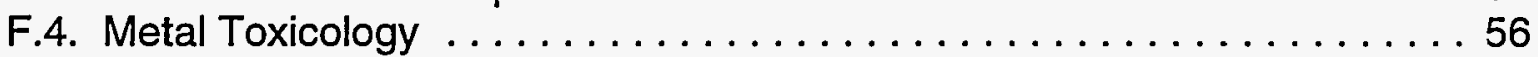

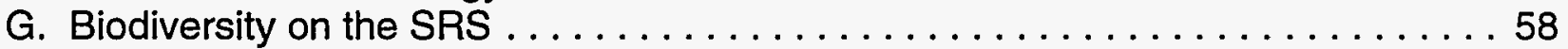

G.1. Resource Management ......................... 59

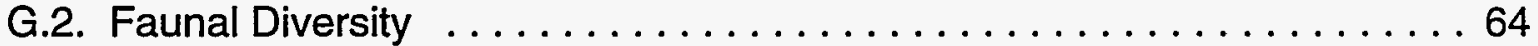

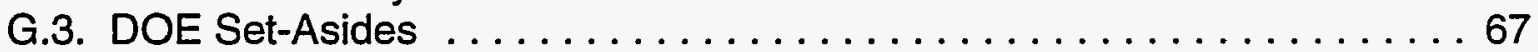

H. Environmental Toxicology . . . . . . . . . . . . . . . . . . . . 70

I. Environmental Outreach and Education $\ldots \ldots \ldots \ldots \ldots \ldots \ldots \ldots \ldots \ldots$

J. Par Pond Drawdown Studies . ......................... 76

J.1. Ecological Effects of the Par Pond Drawdown: Wildlife Studies . . . . 77

J.2. Ecological Effects of the Par Pond Drawdown: Fish and Metal Studies . 79

K. Theoretical Ecology . . . . . . . . . . . . . . . . . . . . . . . 82

L. DOE-SR National Environmental Research Park . . . . . . . . . . . . . 84

M. Wildlife Studies . ............................. 86 
II. AWARDS AND HONORS $\ldots \ldots \ldots \ldots \ldots \ldots \ldots \ldots \ldots \ldots \ldots \ldots$

III. EDUCATION PROGRAM PARTICIPANTS (summers of 1993 and 1994) . . . . . 91
A. Participants in the Education Program

B. Recent Master's and Doctoral Degree Recipients ................. 92

IV. PUBLICATIONS AND PRESENTATION $\ldots \ldots \ldots \ldots \ldots \ldots \ldots \ldots \ldots . \ldots . \ldots . \ldots$
A. Journal Articles and Book Chapters Published
B. Journal Articles and Book Chapters in Press ................. . 104
C. Books Published and In Press . . . . . . . . . . . . . . . . . . 113
D. Presentations . . . . . . . . . . . . . . . . . . . . . . . . 114

APPENDIX . . . .................................. 129

Figure 1. Organizational Chart, Savannah River Ecology Laboratory ........ 130 


\section{SUMMARY}

The Savannah-River Ecology Laboratory (SREL) is a research unit of the University of Georgia (UGA) that is managed in conjunction with the University's Institute of Ecology. The laboratory's overall mission is to acquire and communicate knowledge of ecological processes and principles. SREL conducts basic and applied ecological research, as well as education and outreach programs, under an M\&O contract with the U.S. Department of Energy at the Savannah River Site. Significant accomplishments were made during the year ending July 31, 1994 in the areas of research, education and service.

Major additions and plans to SREL facilities were completed that will enhance the laboratory's work in the future. Following several years of planning, groundbreaking occurred on May 12, 1994 for a 5,000 $\mathrm{ft}^{2}$ multi-purpose conference center that will be funded by the University of Georgia Research Foundation (UGARF) and located on 68 acres of land provided by the Department of Energy. This joint effort between DOE and UGARF supports DOE's new initiative to develop partnerships with the private sector and universities. When completed in late 1994, the facility will be used for scientific meetings and environmental education programs for students, teachers and the general public. Groundbreaking also occurred recently for $6,000 \mathrm{ft}^{2}$ office and library addition to SREL's main building. A 2,000 $\mathrm{ft}^{2}$ addition to SREL's main building was completed last year and now houses the laboratory's computer facility. Work was also finished on a receiving building and a 3,500 $\mathrm{ft}^{2}$ radioecology facility at PAR Pond that includes several laboratories and offices, as well as a modern isotope counting room. Finally, about $\$ 725,000$ in capital equipment was purchased during the past year.

The laboratory's research mission was fulfilled with the publication of three books and 122 journal articles and book chapters by faculty, technical staff, students and visiting scientists. An additional five books and about 100 journal articles are currently in press. Several other noteworthy events took place in the research area. SREL was a co-organizer of the Second International Conference on the Biogeochemistry of Trace Elements that was held in Taipei, Taiwan in September 1993. This, the first such conference organized by SREL to be held outside the United States, brought new recognition to SREL and UGA. The laboratory also organized the Fourth International Conference on the Chemistry and Migration Behavior of the Actinides and Fission Products in the Geosphere that brought more than 250 scientists from around the world to Charleston, S.C. to discuss environmental research, remediation approaches and waste management. Two SREL faculty members, Drs. Sue Clark and Tom Hinton, were among ten American scientists chosen to participate in a young investigator's program sponsored by the National Academy of Sciences on Nuclear Accidents and Radioactive Contamination. Dr. I. Lehr Brisbin was elected to the rank of fellow in the American Association for the Advancement of Science in recognition of over two decades of research in vertebrate ecology and ecotoxicology aimed at understanding the fate and effects of radioactive contaminants in the environment. The second annual SREL Environmental Sciences Symposium was held in Aiken in June 1994. This year's meeting on "Quantitative Ecotoxicology: A Hierarchical Approach" again attracted international participation. 
Participants in SREL's education program in 1993-1994 came from schools located throughout the United States and included 22 undergraduate students, 33 graduate students, 7 pre-college teachers, 3 visiting faculty and 4 high school students. Six minority participants were included among the students. Four students received master's degrees, and two students received doctoral degrees this past year. In addition to being faculty members at the University of Georgia, various SREL faculty have adjunct status at thirteen other colleges and universities.

SREL's faculty, staff and students are active in providing outreach and service to scientific and local communities. Representatives from SREL hold more than 40 editorial or committee positions in national groups and organizations. This past year, Dr. Whit Gibbons was elected chair of the South Carolina Heritage Trust program. SREL representatives also serve on several UGA academic and administrative committees. About 225 lectures, scientific presentations and posters were presented at colleges and universities, including minority institutions. SREL's Division of Outreach and Education reaches a different audience in its successful efforts to communicate scientific awareness to the general public. In 1993, Outreach staff gave more than 300 presentations to schools, civic groups and similar audiences. Representatives of the laboratory also serve the local community by organizing blood drives, managing a recycling program in the laboratory and participating generously in the UGA Campaign for Charities.

Several steps were taken to improve the overall management and operation of the laboratory. The newly-created position of associate director was filled by Dr. Nat Frazer, formerly of Mercer University. Ms. Vivian Harper assumed new duties as environmental coordinator for the laboratory. There was an external review of the laboratory's safety program, an external OSHA-type review and an environmental audit by the Department of Energy. SREL also has its own internal review and inspection program, and is represented on the UGA Chemical and Laboratory Safety Committee. In addition, the SREL quality assurance program conducted two formal assessments of research activities. Finally, an outside peer review was held for the laboratory's (and SRS) biodiversity programs in April 1994, and an outside peer review of research in the Division of Wetlands Ecology was held in July 1994. 


\section{OVERVIEW OF RESEARCH PROGRAMS AND PROGRAM COMPONENTS}

\section{A. ENVIRONMENTAL OPERATIONS SUPPORT}

This field-oriented program emphasizes the use of research opportunities on the SRS while focusing on data information needs of the Department of Energy. Laboratory and special purpose facilities enhance this field-oriented approach. The Savannah River Ecology Laboratory has been gathering baseline information on the long-term aspects of the SRS environment since operations began in 1951. Research programs integrated with Westinghouse's environmental monitoring support the mission of the site and help maintain environmental quality at the SRS. Research in the various program components is summarized in the following sections. 


\section{A.1. SRS IMPACTED WETLANDS}

\section{Natural Succession in Fourmile Branch Delta}

C. J. King, R. R. Sharitz, D. W. Imm, and K. W. McLeod

Since C-Reactor shut down in 1985, the Fourmile Branch corridor and delta have been revegetating through natural succession. In most disturbed habitats, secondary succession begins as seeds in the soil germinate and plants resprout from damaged rootstocks. Because the Fourmile Branch system was affected by thermal effluents from reactor operations for more than 30 years, the soil seed bank was eliminated, and the sprouting ability of the damaged vegetation was lost. Therefore, primary succession began in 1985 with the exposure of the bare sediments, which had been underwater for 30 years.

In 1987, permanent plots were established in the corridor and delta of Fourmile Branch to measure the rate and pattern of plant succession. The vegetation in these plots was sampled in 1987, 1989, and 1993. Early changes in species composition from 1987 to 1989 have been described in previous annual reports. These data are being combined with satellite imagery to assess the invasion of woody plant species in the Fourmile Branch delta system since reactor shutdown.

Aerial photography taken in 1985, 1990, and 1993 are being rectified and classified using Geographic Information System (GIS) Technology. Data from the field sampling are being summarized to determine major types of woody plant associations and to assess the accuracy of the classifications. The classified images are being analyzed using change detection techniques to determine the location and quantity of woody plant invasion. This research documents patterns and rates of natural succession in disturbed wetlands and may serve as a framework for evaluating the effectiveness of wetland restoration programs.

\section{Carolina Bay Restoration}

R. R. Sharitz, B. E. Taylor, and G. R. Wein

Many of the Carolina bays located on the SRS have ditches that originally functioned to either drain water from or into these natural depressions for agricultural purposes. While these ditches were dug prior to 1951, some of them still function. This in turn alters the wetland vegetation expected in a bay to that of a more upland pine-hardwoods plant community. In one bay on the SRS, the four ha Carolina Bay 93, aerial photography indicates that in 1951 it was dominated by herbaceous vegetation but has since become forested with loblolly pine and sweetgum. Present in the bay is an active ditch that drained the bay in the past.

SREL and SRFS have developed a cooperative research program to evaluate the effects of restoring hydrology and other treatments that might be necessary to restore ecosystem functions of a Carolina bay. In November 1993 the ditch present in Carolina Bay 93 was plugged; approximately $50 \%$ of the timber was removed; and a portion of the remaining forest and clearcut was burned to remove existing litter. Plant community development, 
impacts on water quality, soil carbon-nitrogen changes, zooplankton community development, and past history of the bay are being investigated.

Water levels during the first year of restoration were greater than seen in years when the ditch was unplugged but were still lower than expected. This was due to low rainfall during the winter and spring of 1994. Preliminary results indicate that a portion of the bay's original seedbank may have survived the dryer hydrologic conditions since 1951 and recruitment of wetland vegetation has occurred to the extant plant community in the wetter portions of the bay. Surface soil nutrients are distributed heterogeneously, while the subsurface nutrients are not. This is probably due to past vegetation or hydroperiod.

\section{Recent Publications: SRS Impacted Wetlands}

McLeod, K. W., M. R. Reed, and T. G. Ciravolo. Selection of woody species for bottomland restoration. Proceedings of the 21st Annual Conference on Wetlands Restoration and Creation (in press).

McLeod, K. W., G. R. Wein and R. R. Sharitz. 1993. Wetland restoration for habitat reconstruction and contaminant stabilization. p. 1043-1047. In Proceedings of ER'93 Environmental Remediation Conference, U. S. Department of Energy. Washington, DC.

Reed, M. R. and K. W. McLeod. Planting unconsolidated sediments with flood-tolerant species. Proceedings of the 21st Annual Conference on Wetlands Restoration and Creation (in press). 


\section{A.2. SRS STREAMS}

\section{Ecology of Savannah River Site Streams}

J V. McArthur

During the past year, we have initiated studies to 1) determine gene exchange among native aquatic bacteria, 2) estimate plasmid diversity within a specific population of bacteria and within the whole bacterial assemblage along the Upper Three Runs Creek drainage, and 3 ) begin preliminary determinations of the role of bacteriophage in controlling bacterial populations and gene exchange among native aquatic bacteria. We also completed studies examining the spatial and temporal variability of a benthic bacterial population. All of these studies are developed around the theoretical construct of information spiralling. We have continued our studies that show that plasmids carrying genes for mercury resistance and/or antibiotic resistance are transferred from natural donors. These observations are important as many microbial functions may be similarly transferred. Any process that inhibits or enhances these exchange rates will ultimately affect ecosystem function and the ability of microbes to process contaminants. The work with the bacteriophage, if successful, will be another first: demonstration of the coupling of two separate evolutionary mechanisms. This has not only immediate value to science in general but also to our understanding of the way stream ecosystems function. Our ultimate goal continues to be relating bacterial genetic processes to ecosystem functions.

\section{Recent Publications: SRS Streams}

Leff, L. G., J V. McArthur, and L. J. Shimkets. 1993. Spatial and temporal variability of antibiotic resistance in freshwater bacterial assemblages. FEMS Microbiology Ecology 13:135-144.

Leff, L. G. and J V. McArthur. 1994. Effect of macroinvertebrates on detachment of bacteria from biofilms in stream microcosms. Journal of the North American Benthological Society 13:74-79.

McArthur, J V., J. M. Aho, R. B. Rader, and G. L. Mills. 1994. Interspecific leaf interactions during decomposition in aquatic and floodplain ecosystems. Journal of the North American Benthological Society 13:57-67. 


\title{
A.3. TRACE ORGANIC COMPOUNDS
}

\section{Transport of Contaminant Organic Compounds}

\author{
G. L. Mills and R. J. Hudson
}

Numerous studies have examined the behavior of organic solutes in relatively simple solution-solid phase mixtures. Many of these studies have been limited to a single solute. However, petroleum distillates such as kerosine, diesel oil, and gasoline, are complex mixtures of hydrocarbon molecules including normal, branched, and cyclic aliphatic compounds, as well as mono- and polycyclic aromatic hydrocarbons (PAH). The sorptive behavior and consequent mobility of these hydrocarbon components will be profoundly influenced by changes in both the solution and solid phase in petroleum-contaminated systems. Higher molecular weight aliphatic components will preferentially sorb to the solid phase, thus increasing the hydrophobicity of the surface. This may be particularly important in subsoils or aquifer sediments where the natural organic matter content is low. In addition, in low carbon environments specific adsorption rather than partitioning to natural organic matter may be the predominant sorption mechanism.

Studies have been completed to determine the sorptive properties of weathered diesel oil by (i) comparing measured hydrophobic organic compound (HOC) sorption coefficients (K) in diesel-contaminated aquifer material versus uncontaminated aquifer material, and (ii) examining the effect of various concentrations of residual diesel oil on HOC transport through columns of aquifer material. A secondary objective is to determine the effects of single versus multiple organic solute systems on HOC sorption to aquifer material.

The sorptive properties of weathered diesel oil were investigated by conducting miscible displacement experiments with three hydrophobic organic compounds, acenapthene, fluorene, and dibenzothiophene, as tracers in columns containing aquifer materials low in natural organic carbon $\left(f_{\mathrm{oc}}=0.0002\right)$ and contaminated with 0 to $0.02 \% \mathrm{w} / \mathrm{w}$ of a moderately weathered diesel oil. Weathered diesel oil behaved as a highly effective sorptive phase, retarding the transport of HOCs through aquifer materials. A comparison between sorption coefficients $(\mathrm{K})$ for uncontaminated and oil-contaminated aquifer material showed that HOC sorption increased linearly with diesel oil content from 2 to 10 times aquifer material alone. By comparing oil-water sorption coefficients $\left(\mathrm{K}_{\mathrm{oil}}\right)$ to literature carbon-normalized sorption coefficients $\left(\mathrm{K}_{o c}\right)$, weathered diesel oil was about 3 times more effective as a sorptive phase than natural organic carbon per unit mass. The octanol-water partition coefficients $\left(\mathrm{K}_{\mathrm{ow}}\right)$ for the three solutes were found to be reasonable estimates of $\mathrm{K}_{\mathrm{oil}}$ values. Differences in $\mathrm{K}$ values from multiple and single tracer inputs suggested competition was occurring between HOCs for sorption sites in uncontaminated aquifer material. These differences and the disagreement between measured and published $\mathrm{K}_{\mathrm{oc}}$ values indicated that natural organic carbon was not dominating HOC sorption, and significant adsorption to the mineral surfaces was occurring. Decreased HOC mobility from sorption to weathered diesel oil will affect remediation strategies, such as pump and treat systems, vacuum extraction systems, and mathematical transport models based on $f_{o c}$ and literature $\mathrm{K}_{\mathrm{oc}}$ values. 
New studies examining the effects of organic co-contaminants in the aqueous phase on the sorptive behavior of PAH in aquifer substrates containing residual diesel oil have been initiated. Contaminated sites often contain a complex mixture of organic compounds encompassing a broad range of chemical and physical properties. For example, volatile chlorinated hydrocarbons (VCH) such as TCE and PCE, are commonly found as cocontaminants with petroleum derived pollutants. Volatile $\mathrm{CHC}$ have a significant water solubility and in high concentration will modify the properties of the aqueous phase. Current studies are examining the effects of dissolved $\mathrm{VCH}$ in the aqueous phase on the transport of acenapthene, fluorene, and dibenzothiophene in diesel contaminated aquifer sediments using our experimental column system.

\section{Recent Publication: Trace Organic Compounds}

Hudson, R. J. 1994. Weathered diesel oil as a sorptive phase for hydrophobic organic compounds in aquifer material. M.S. Thesis, Texas A\&M University.

McArthur, J V., J. M. Aho, R. B. Rader, and G. L. Mills. 1994. Interspecific leaf interactions during decomposition in aquatic and floodplain ecosystems. Journal of the North American Benthological Society 13:57-67. 


\section{A.4. RADIOECOLOGY}

\section{Radioecological Studies of the PAR Pond System}

F. W. Whicker and T. G. Hinton

The drawdown of the PAR Pond reservoir exposed $5 \mathrm{~km}^{2}$ of sediments containing low levels of radionuclides, primarily ${ }^{137} \mathrm{Cs}$. Studies on the exposed PAR Pond sediments were initiated in July 1991 and will continue through refill. Principal findings this year were:

- Radiation exposure rates at 1 meter above the exposed lake bed averaged $8 \mu \mathrm{R} / \mathrm{hr}$ above background. Areas of the reservoir that were points of contaminant input (Hot and North Arms) have readings $30-50 \%$ higher than others (West Arm). Radiation exposure rates increased about $30 \%$ after the initial drawdown due to reduced shielding when the sediments dried out.

- Garden vegetables were grown on the exposed lake bed and ${ }^{137} \mathrm{Cs}$ concentrations in plants were 1 to 6 times greater than the concentrations in the sediments. Such high concentration ratios are significantly larger than values used in generic risk analysis computations, highlighting the need for site-specific data. ${ }^{137} \mathrm{Cs}$ concentrations in the vegetables after the addition of potassium fertilizer were 2 to 3 times lower; the amount of reduction depended on the type of vegetable.

- Samples of native vegetation growing on the exposed sediments revealed high concentration ratios (10 - 15 for Juncus and Scripus). Preliminary analyses suggest that the concentration ratios for some species may have increased in 1994 compared to 1993.

- Concentrations of ${ }^{137} \mathrm{Cs}$ in bass have doubled since the drawdown. The increase is significantly correlated $(\mathrm{p}<0.01)$ to a decline in stable potassium concentrations in the water $(R=-0.70)$, and to a general decline in fish health as indicated by a condition factor $(p=0.04, R=-0.53)$. We suspect this is because much less nutrient-rich Savannah River water is pumped into the reservoir than was the case prior to drawdown.

- Sediment cores revealed that all the ${ }^{137} \mathrm{Cs}$ is in the upper $30 \mathrm{~cm}$, with a peak concentration occurring between 4 and $8 \mathrm{~cm}$. In about 8 of 12 locations studied, the peak ${ }^{137} \mathrm{Cs}$ levels have shifted towards the surface. This shift appears due to decompostion of organic matter in the near-surface sediment layers.

- Dose calculations indicate that a person subsisting on the unremediated, exposed sediments for 30 years could receive an effective dose equivalent of $50 \mathrm{mSv}$ from the external, ingestion and inhalation pathways. This results in a probability of 0.0026 of contracting a fatal cancer from the dose received. These risks are small compared to the actuarial fatal cancer incidence of about 0.20 , but greater than the EPA risk guidelines of 0.0001 set for cleanup standards under CERCLA. Thus remediation efforts may be required if subsistence farming is the long-term land use chosen for PAR Pond.

- Ecological risk calculations were performed for fish inhabiting the PAR Pond system over the last 30 years using a screening-type modeling approach. Conservative dose estimates to the fish were $0.2 \mathrm{mGy} \mathrm{d}^{-1}$. The probability of fish mortality occurring at this dose rate is extremely low, as mortality and reproductive impairment have not been documented at levels below $10 \mathrm{mGy} \mathrm{d}^{-1}$. The probabilities are especially low because we are confident that the actual doses received by fish were less than our intentionally conservative calculations. 
- Major ecological components within Pond B were resampled for ${ }^{137} \mathrm{Cs}$ concentrations, 10 years after a complete inventory was made of Pond $\mathrm{B}$, to test hypotheses concerning the long-term fate of radionuclides within aquatic systems.

- The PAR Pond Radioecology Laboratory had its grand opening in October 1993. The new facility substantially increases our research capabilities.

- Educational training in radioecological studies at the PAR Pond Laboratory increased this year by involving students from Colorado State University, Emory University, Paine College, and the University of South Carolina.

\section{Radionuclide Environmental Chemistry}

S. B. Clark

The inventory and speciation of radioactive contaminants play a major role in predicting their fate and transport in various ecosystems. Knowledge of the level of contaminants as well as an understanding of their site-specific speciation are essential for estimating potential risks and developing cost-effective remediation strategies. Research efforts for this year have continued on the development of simplified, low-level detection methods for radioactivity in environmental samples, the use of these methods to determine inventories of contaminants in biogeochemical components of various environmental systems, and the study of mechanisms controlling the transport of contaminants in these ecosystems.

A simplified method for the determination of radiostrontium in calcium-based matrices has been developed and is used routinely to determine levels of Sr-90 in mollusk shells and skeletal tissues collected from PAR Pond, Pond B and Chernobyl. Other techniques for determining transuranic contaminants in aqueous and sediment samples have been developed and reported.

Mechanistic studies include research into the various modes of metal interactions with natural organic matter and clay surfaces typically encountered in the SRS subsurface. Using kinetic techniques, various modes of metal binding to natural humic material have been described. In addition, mechanistic information concerning metal binding to clay surfaces has facilitated contaminant transport modeling efforts. These studies indicate that adequate descriptions of these interactions are essential for predicting radioactive contaminant transport scenarios.

Other noteworthy technical progress included the hosting of the 1993 Conference on the Chemistry and Migration Behavior of the Actinides and Fission Products in the Geosphere. In addition, Drs. Sue Clark and Tom Hinton were selected by the National Academy of Sciences (NAS) to participate in the Young Investigator Program on Nuclear Accidents and Radioactive Contamination in the Environment. The NAS activity resulted in a visit by US, Ukrainian, and Belarussian scientists to the SRS, which included tours of site facilities and discussions of environmental problems relevant to both DOE and the Chernobyl area. Both the conference and NAS activities resulted in positive public relations opportunities for the SRS, as well as important technical information exchanges related to radioecological research at SREL. 


\section{Resuspension of Contaminated Soil}

\section{T. G. Hinton}

This research examines the resuspension of contaminated soil particles onto vegetative surfaces. Our goal is to determine the conditions when inadvertent ingestion of soil by grazing animals might constitute an important pathway of contaminant intake. We are additionally interested in the fate of the soil and attached radionuclides once they are deposited on plants. Technical highlights for this year included the following:

- Naturally occurring titanium has historically been used as a soil tracer to estimate the mass of soil loaded on plants. Researchers in Ireland and the UK have recently questioned the applicability of the Ti technique. The PAR Pond laboratory has been examining the particle size dependence of $\mathrm{Ti}$ and ${ }^{137} \mathrm{Cs}$ in these same Ireland and $\mathrm{UK}$ soils to try to determine where the problem lies. Unlike most soils, these problem soils seem to have few particles less than $20 \mu \mathrm{m}$ in diameter; or more precisely, the small particles have conglomerated with colloids and organic matter so that they behave like larger-sized particles. This causes a bias in the soil loading estimate.

- We have developed a technique to quantify the particle size distribution of soil on surfaces of broad-leaved plants using a plastic stripping method to remove the soil and a computer-coupled microscope to determine the particle characteristics. We hope this information will overcome the bias mentioned above. The technique needs to be refined, however, so that it is appropriate for grasses.

- A series of chemical extraction experiments are nearing completion that compare the availability of ${ }^{137} \mathrm{Cs},{ }^{90} \mathrm{Sr}$ and ${ }^{239} \mathrm{Pu}$ at two sites in Ukraine to sediments from PAR Pond.

\section{Recent Publications: Radioecology}

Bowling, J. W. , J. E. Pinder, III, R. F. Lide, K. A. Orlandini, and W. R. Penrose. 1994. Sedimentation flux of plutonium in a warm, monomictic reservoir. Journal of Environmental Radioactivity 22:111-126.

Bryce, A. L., W. A. Kornicker, A. L. Elzerman, and S. B. Clark. Nickel (II) interactions with hydrous ferric oxide surfaces in the presence of EDTA. Environmental Science and Technology (in press).

Cadieux, J. R., S. B. Clark, R. A. Fjeld, S. Reboul, and A. Sowder. Measurement of actinides in environmental samples by photon-electron rejecting liquid scintillation. Nuclear Instruments and Methods in Physics Research (in press).

Hinton, T. G. 1993. Variation among model predictions within an IAEA validation exercise. p. 138-143. In Proceedings of the Topical Meeting on Environmental Transport and Dosimetry, American Nuclear Society, Charleston, South Carolina.

Hinton, T. G. 1994. Sensitivity analysis of ECOSYS-87: An emphasis on the ingestion pathway as a function of radionuclide and type of deposition. Health Physics 66:513-531.

Hinton, T. G., P. Kopp, S. Ibrahim, I. Bubryak, A. Syomov, and L. Tobler. 1993. Contaminated soil on Chernobyl vegetation. p. 407-421. In Proceedings of the Twenty-Sixth Midyear Topical Meeting of the Health Physics Society: Environmental Health Physics, edited by R. L. Kathren, D. H. Denham, and K. Salmon. Columbia Chapter, Health Physics Society, Coeur d'Alene, ID. 
Hinton, T. G., P. Kopp, S. Ibrahim, I. Bubryak, A. Syomov, L. Tobler, and C. Bell. A comparison of techniques used to estimate the quantity of soil resuspended onto plant surfaces. Health Physics (in press).

Hinton, T. G. and F. W. Whicker. A screening model approach to determine probable impacts to fish from historic releases of radionuclides. Science of the Total Environment (in press).

Johnson, W. H., S. M. Serkiz, and S. B. Clark. Determination of site specific distribution coefficients of mixed waste contaminants using an in situ approach. In Proceedings of the 27th Midyear Topical Meeting of the Health Physics Society: Managing Radioactive and Mixed Waste, Health Physics Society National Meeting, Albany, NY (in press).

Pinder, J. E., III, J. W. Bowling, R. L. Lide, and L. B. Oliver. The distribution of ${ }^{137} \mathrm{Cs}$ in sediments of the littoral zone of a former reactor cooling pond. Journal of Environmental Radioactivity (in press).

Rao, L. F., G. R. Choppin, and S. B. Clark. Study of metal-humate interactions by cation exchange. Radiochimica Acta (in press).

Whicker, F. W., T. G. Hinton and D. J. Niquette. The effects of a partial drawdown on the dynamics of ${ }^{137} \mathrm{Cs}$ in an abandoned reactor cooling reservoir. Science of the Total Environment (in press).

Whicker, F. W., T. G. Hinton, D. J. Niquette, and J. Seel. 1993. Health risks to hypothetical residents of a radioactively contaminated lake bed. p. 619-624. In Proceedings of ER'93 Environmental Remediation Conference, U.S. Department of Energy. Washington, DC.

Whicker, F. W., D. J. Niquette, and T. G. Hinton. 1993. To remediate or not: A case history. p. 473-485. In Proceedings of the Twenty-Sixth Midyear Topical Meeting of the Health Physics Society: Environmental Health Physics, edited by R. L. Kathren, D. H. Denham, and K. Salmon. Columbia Chapter, Health Physics Society. Coeur d'Alene, ID. 


\section{A.5. DATABASE SYNTHESIS}

\section{Research Data Archive Activities}

R. K. Chesser and J. Heuer

The Data Synthesis program is motivated by the understanding that much of the data collected by scientists associated with SREL has intrinsic value for this and future generations. Many of the studies represent measurements of phenomena in a unique space and time and thus cannot be duplicated if lost. Recent emphasis on long-term climatic changes suggests that historical data may become more valuable in the future than when initially collected. In response to these considerations, nearly 250 studies encompassing nearly 800 data files have been included in a computer-based research data archive. These data files are stored in a readily accessible computer format on a high volume read/write optical disk system attached to the central computing facility. This system features excellent data security and is included in detailed backup procedures that are designed to nearly eliminate the chance of accidental loss of data. The link between the data archive process and the publication of peer-reviewed articles at the Laboratory has been enhanced. The transfer of the operation of the Data Archive application to a Novell network server is still ongoing, although initial design changes have been completed. 


\section{STUDIES INCLUDED IN THE SREL DATA ARCHIVE SYSTEM}

This is an inclusive listing of SREL Data Archives from August 1, 1993 to July 31, 1994.

\begin{tabular}{|c|c|c|}
\hline Abbreviated Study Title & $\begin{array}{c}\text { Principal } \\
\text { Investigator }\end{array}$ & $\begin{array}{l}\text { Contact } \\
\text { Person }\end{array}$ \\
\hline Land application of waste industrial oils & Adriano & Adriano \\
\hline Est. resuspended soil loadings on plant surfaces & Adriano & Adriano \\
\hline Chemical speciation of $U$ by micro X-ray absorption spectroscopy & Bertsch & Bertsch \\
\hline New Guinea singing dog study & Brisbin & Brisbin \\
\hline Alligator feeding study & Brisbin & Brisbin \\
\hline Alligator movement study & Brisbin & Brisbin \\
\hline Cesium uptake by PAR Pond alligators & Brisbin & Brisbin \\
\hline Boat bird surveys of selected SRS habitats & Bryan & Brisbin \\
\hline Tree growth in D-area & Carlson & Adriano \\
\hline Genetic structure of wild turkeys on the SRS & Chesser & Chesser \\
\hline Chemical controls on colloid generation and transport & Clark & Clark \\
\hline GPS vs. map rectification study & Cooke & Pinder \\
\hline Mychorrhizal study & Dosskey & Adriano \\
\hline Additional data for Bachman sparrow study & Dunning & Chesser \\
\hline White blood cell flow cytometric techniques & Fisher & Jagoe \\
\hline Effect of freezing on flow cytometric analyses & Fisher & Jagoe \\
\hline Female cloacal anatomy of Ambystoma talpoideum & Gibbons & Gibbons \\
\hline Effect of food limitation on marbled salamander & Gibbons & Gibbons \\
\hline Nesting behavior of $T$. scripta on SRS & Gibbons & Gibbons \\
\hline Water finding orientation in turtles & Gibbons & Gibbons \\
\hline Attraction of turtle nest predators by flat markers & Gibbons & Gibbons \\
\hline Secretion and sperm storage in spermathecae of Ambystoma opacum & Gibbons & Gibbons \\
\hline Response of tomato to long-term $\mathrm{K}$ and lime application & Harris & Adriano \\
\hline Demographics and population genetic structure in the ea & Hartman & Smith \\
\hline
\end{tabular}




\begin{tabular}{|c|c|c|}
\hline Abbreviated Study Title & $\begin{array}{c}\text { Principal } \\
\text { Investigator }\end{array}$ & $\begin{array}{c}\text { Contact } \\
\text { Person } \\
\end{array}$ \\
\hline Radionuclide and heavy metal uptake by the aquatic ecosystem of PAR Pond & Hinton & Hinton \\
\hline Radionuclide and heavy metal uptake by the terrestrial ecosystem of PAR Pond & Hinton & Hinton \\
\hline Tetraphenylboron study & Hunter & Bertsch \\
\hline Energetics of the green anole & Jenssen & Congdon \\
\hline Animal impact accident study & Johns & Smith \\
\hline Genetics of black bear & Johns & Smith \\
\hline Genetic effects of habitat fragmentation on root vole & Kandl & Smith \\
\hline Mobile colloid lysimeter study & Kaplan & Bertsch \\
\hline F-area contaminant transport study & Kaplan & Adriano \\
\hline Use of pressure transducers & Keeland & Sharitz \\
\hline Effect of hydrologic regime on growth of bald cypress & Keeland & Sharitz \\
\hline Nesting characteristics of common moorhen and purple gallinule & Kennamer & Brisbin \\
\hline Woody plant regeneration study & King & Sharitz \\
\hline Congaree study & King & Sharitz \\
\hline Additional seeding demography study data & King & Sharitz \\
\hline Macroinvertebrate drift in lower Mississippi River & Koetsier & McArthur \\
\hline Paternity exclusion study in Ambystoma opacum & Krenz & Smith \\
\hline Mating characteristics in paedomorphic Ambystoma talpoidum & Krenz & Smith \\
\hline Flow cytometry study of seepage basin slider turtles & Lamb & Smith \\
\hline Flow cytometry study of gopher tortoise & Lamb & Smith \\
\hline Pen Branch water levels & Lide & Sharitz \\
\hline Germination study & Martin & Adriano \\
\hline Upper Three Runs tricoptera survey & McArthur & McArthur \\
\hline Distribution of asiatic clams & McArthur & McArthur \\
\hline NPR invertebrate study & McArthur & McArthur \\
\hline Cross 1952 light trap study & McArthur & McArthur \\
\hline Effects of thermal stress on bald cypress and water tupelo & McLeod & McLeod \\
\hline Reproduction of loblolly pine in field $3-412$ & McLeod & McLeod \\
\hline Effects of anaerobic soil culture on southern pine seedlings(Exempted) & McLeod & McLeod \\
\hline
\end{tabular}




\begin{tabular}{|c|c|c|}
\hline Abbreviated Study Title & $\begin{array}{c}\text { Principal } \\
\text { Investigator }\end{array}$ & $\begin{array}{l}\text { Contact } \\
\text { Person }\end{array}$ \\
\hline Water potential of sandhill oaks & McLeod & McLeod \\
\hline Water potential of pines as affected by straw removal & McLeod & McLeod \\
\hline Germination and growth of cypress in a thermal environment & McLeod & McLeod \\
\hline Growth of 1-year old cypress in a thermal environment & McLeod & McLeod \\
\hline Longleaf pine rain study & McLeod & McLeod \\
\hline Germination study of bottomland hardwoods & McLeod & McLeod \\
\hline Effect of sludge addition on pine plantations & McLeod & McLeod \\
\hline Effect of habitat parameters on life history characteristics of mosquitofish & Meffe & Meffe \\
\hline Maintenance of sex in a clonal/sexual fish species complex & Meffe & Meffe \\
\hline Inter. and instrapecific variation of snails & Mulvey & Mulvey \\
\hline Snail genetics study & Mulvey & Mulvey \\
\hline Deer parasite study & Mulvey & Mulvey \\
\hline Size dependent toxicity in mosquitofish & Newman & Newman \\
\hline Additional mercury survey study data & Newman & Newman \\
\hline Radiocesium in plants from Steel Creek floodplain & Pinder & Pinder \\
\hline${ }^{137} \mathrm{Cs}$ in Pond $\mathrm{B}$ littoral zone sediments & Pinder & Pinder \\
\hline Elemental concentration of PAR Pond sediments & Pinder & Pinder \\
\hline Biosphere II study data & Scribner & Smith \\
\hline Landscape contribution to seed banks in Carolina bays & Sharitz & Sharitz \\
\hline Risher Pond observations & Smith & Smith \\
\hline Old field mammal trapping study & Smith & Smith \\
\hline Genetic variation in Peromyscus leucopus and $P$. gossypinus & Smith & Smith \\
\hline Genetic structure of wintering pop. of American coots & Smith & Smith \\
\hline Effect of temperature on gambusia genetics & Smith & Smith \\
\hline mtDNA study of mainland and barrier island deer & Smith & Smith \\
\hline Sexual dimorphism of the SW earless lizard & Sugg & Chesser \\
\hline Geographic patterns for morphological traits of Texas mouse & Sugg & Chesser \\
\hline Effects of contamination on genetic damage of largemouth bass & Sugg & Chesser \\
\hline Largemouth bass health assessment study & Sugg & Chesser \\
\hline Zooplankton genetics study & Taylor & Taylor \\
\hline
\end{tabular}




\begin{tabular}{||l|l|l||}
\hline \multicolumn{1}{|c|}{ Abbreviated Study Title } & \multicolumn{1}{|c|}{$\begin{array}{c}\text { Principal } \\
\text { Investigator }\end{array}$} & \multicolumn{1}{|c|}{$\begin{array}{c}\text { Contact } \\
\text { Person }\end{array}$} \\
\hline L Lake shoreline characterization study & Wein & Wein \\
\hline Remediation of contaminated soil - PAR Pond Garden Experiment & Whicker & Hinton \\
\hline Effect of flooding on false ring formation in cypress & Young & Sharitz \\
\hline & & \\
\hline & & \\
\hline & & \\
\hline & & \\
\hline & & \\
\hline
\end{tabular}




\title{
Waterfowl Research on the SRS
}

\author{
R. A. Kennamer and I. L. Brisbin, Jr.
}

Annual aerial surveys of SRS wintering waterfowl were completed in March 1994 and provided a continued evaluation of the effects of the PAR Pond drawdown on these birds. In the two winters following the winter of 1991-92 when the reservoir was initially drawn down, there have been substantial increases in waterfowl use of PAR Pond as the lake at its current reduced level has regained aquatic vegetation and important invertebrate prey species, including the asiatic clam. The maximum waterfowl count during the winter of 1993-94 was 1,783 individuals, as compared to the maximum of 783 individuals immediately following the drawdown.

During November and December of 1993, 1,055 ring-necked ducks were captured, banded, and released at PAR Pond and L-Lake. Since 1985, when the annual trapping was initiated, about 5,000 individuals of this species have been banded and released at the site. Hunter recoveries of these birds that are reported to the Federal Bird Banding Lab provide information on the geographical range within which individuals of this species may be found following their use of site reservoirs. Of particular interest during the past year was the recovery of a SRS banded ring-necked duck that was harvested by a hunter near Camaguey in Cuba on January 10, 1994.

The 1994 wood duck nesting season was 40 days shorter than the previous breeding season and resulted in 46 fewer nests in 1994 than in 1993 (195 vs. 149 nests). In 1994, 2,201 eggs were laid in SRS wood duck boxes (excluding those eggs laid in PAR Pond boxes). Seventy-six nests were successful and produced a total of 883 ducklings. Nest abandonments amounted to 45 nests and predation occurred in 28 nests. The average number of eggs found in SRS wood duck nests was 15. PAR Pond nest box use has not yet been determined for the 1994 nesting season.

During an eight-year study, 253 wood duck nests were used to examine factors affecting wood duck clutch size and egg size seasonal declines. Clutch sizes tended to be similar at the start of both wet and dry nesting seasons, but clutch sizes declined more abruptly during the faster drying years than during wet years. Fresh egg mass was only related to the female body mass, with larger females tending to nest earlier and lay heavier eggs.

In a study of wood duck egg composition, 138 eggs were collected from Pond B nest boxes, and separated into their components of yolk, albumen, and shell. Components were oven-dried, and yolk samples were extracted to determine lipid content. The lean-dry yolk samples were further ashed in a muffle furnace. The effects of egg size, clutch size, laying sequence, and skipped days of laying on egg composition were investigated. 
Genetic and Demographic Analysis of White-tailed Deer

M. H. Smith and R. K. Chesser

Techniques for data collection have been worked out for deer, and it is now just a matter of continuing to collect appropriate data in most cases. We have also developed techniques for the analyses of mitochondrial DNA sequences and are developing techniques for the analysis of mini-satellite DNA. This work was started by Dr. Purdue from Illinois when he was working on deer bones from archeological sites on the SRS. These techniques are also being applied to tissue extracts from samples taken at SRS deer hunt check stations. Data indicate the existence of additional fragmentation of the SRS herd beyond that already documented by the use of allozymes. The highly structured nature of this herd may indicate that management targeted to highly localized areas on the SRS would be successful in reducing the deer-car accident rate. Spatial-temporal analysis of car-deer accidents is being continued to identify potential "hot spots" and to help in the development of any specialized management plans that may be necessary. Regional comparisons of genetic differentiation between deer herds indicate relatively little genetic exchange among populations, especially for females.

The analysis of density changes over the years was published and continues to be used to make comparisons for current changes in the herd, which peaked during 1992 and started a slight decline in 1993 after the fall hunts. We have had in depth discussions with SRFS personnel on the management strategies for the SRS herd and will continue these exchanges, especially in reference to specialized management strategies for reducing car-deer accidents. Relationships between parasite burdens and changes in functional characteristics (such as reproductive performance) and morphological characteristics (such as fluctuating asymmetry) have been elucidated recently and may be important to understanding future behavior of the SRS herd especially as an additional stressor on the deer herd. Papers have been published or submitted during the last year elucidating the various effects of density changes on individual deer including growth rate (Leberg and Smith 1993), reproductive output and parasite burdens. Papers have been published during the last year elucidating changes in reproductive output (Rhodes et al. 1987) and parasite burdens (Mulvey et al. 1994). A recently submitted paper on the analysis of the genetic data for associations among genetic loci has shown a time period that appears to be unique in the effects it has had on the genetic and demographic composition of the SRS deer herd. Analysis of morphological asymmetry data to date has indicated that the SRS deer herd appears to function, as previously reported, as two separate herds, one in the upland areas, and another along the Savannah River swamp.

\section{Population Ecology of Turtles at Ellenton Bay}

J. W. Gibbons

As human populations and their related activities have increased, natural habitats all over the globe have been destroyed or compromised. Entire populations of many species have been eliminated or reduced. Establishing population trends of species in habitats upon which the level of human impact is equivocal is quite difficult. Protected research areas on the Savannah River Site have allowed us to assess annual population levels of resident 
species of turtles for more than two decades. Such long-term study has allowed us to monitor population fluctuations that occur as a result of normal extremes of environmental variation in several different habitat types. (Short-term funding experienced by most researchers frequently result in short-term studies on short-lived animals.) The continued funding which we have received at SREL due to DOE's commitment to SRS research has had a major impact on our knowledge of life history characters and phenomena in long-lived reptiles, many of whom do not reproduce until five years of age or older, and who then continue to reproduce beyond the age of 30 years. Such long-term studies are key to our understanding of the environmental sources of selection on reptile life history ecology.

From 1993 through 1994 our major emphasis has been a continuation of turtle ecology studies at Ellenton Bay and surrounding aquatic areas, which were initiated in 1967 and have been continued intermittently since then. Drought conditions of the 1980 s and the subsequent flooding in the winter of 1992-93 have allowed us to compare the responses of several sympatric species to these environmental extremes. The common mud turtle (Kinosternon subrubrum) and the yellow-bellied slider turtle (Trachemys scripta) are the two most abundant and intensively studied species at Ellenton Bay. Life history data have also been gathered on eight other species which occur there in smaller numbers. From October 1993 through August 1994 we recorded 184 original captures and 265 recaptures of eight species. Turtles were measured, marked (or existing $\mathrm{ID}$ code was recorded), and released at the site of capture. Radio transmitters were temporarily attached to females exiting the aquatic area to nest, and were subsequently followed to their nesting sites. Temporary and permanent aquatic habitats near Ellenton Bay were trapped (as they have been in the past) to gain more insight into the movement between, and utilization of, different wetlands by coexisting species of freshwater turtles with contrasting life history strategies.

The nesting and reproductive information being gathered will augment that from the previous year which was virtually the first comprehensive study of the species which nest at Ellenton Bay. Research on both the movement and nesting behavior of these turtles is relevant to reaching an environmentally rational definition of wetlands that includes the surrounding terrestrial habitats.

\section{Recent Publications: Wildlife Studies}

Burke, V.J., N.B. Frazer, and J.W. Gibbons. 1993. Conservation of turtles: the Chelonian dilemma. p. 35-38. In Proceedings of the 13th Annual Symposium on Sea Turtle Biology and Conservation, U.S. Dept. of Commerce, National Oceanic and Atmospheric Administration. Jekyll Island, GA.

Burke, V.J., J.W. Gibbons, and J.L. Greene. 1993. Prolonged nesting forays by common mud turtles (Kinosternon subrubrum). The American Midland Naturalist 131:190-195.

Burke, V.J., J.L. Greene, and J.W. Gibbons. The effect of sample size and study duration on metapopulation estimates for slider turtles (Trachemys scripta). Herpetologica (in press).

Leberg, P. L., and M. H. Smith. 1993. Influence of density on growth of white-tailed deer. Journal of Mammalogy 74:723-731. 
Mulvey, M., J. M. Aho, and O. E. Rhodes Jr. 1994. Parasitism and white-tailed deer: timing and components of female reproduction. Oikos 70:177-182.

Novak, J. M., O. E. Rhodes Jr., M. H. Smith and R. K. Chesser. 1993. Morphological asymmetry in mammals: genetics and homeostasis reconsidered. Acta Theriologica 38, Suppl. 2: 7-18.

Rhodes, O. E., Jr., and R. K. Chesser. 1994. Genetic concepts for habitat conservation: The transfer and maintenance of genetic variation. Landscape and Urban Planning 28:55-62.

Rhodes, O. E., Jr., M. H. Smith, K. T. Scribner, and P. E. Johns. 1987. Factors affecting productivity of a white-tailed deer herd. p. 219-222 In Global Trends in Wildlife Management. Transactions of the 18th IUGB Congress, edited by B. Bobek, K. Perzanowski, and W. Regelin. Swiat Press, Krakow, Poland. 


\section{A.7. ZOOPLANKTON}

\section{Zooplankton in Carolina Bays and Other Temporary Ponds}

B. E. Taylor, A. E. DeBiase and D. L. Leeper

A broad spectrum of research is supported under the Zooplankton program. The program is focused on Carolina bays, and its components concern trophic structure of the aquatic community, biogeography of certain groups of taxa, and history of the ponds.

In 1993 we completed field sampling for a 2-year study on invertebrate secondary production in Rainbow Bay. The results will contribute substantially to our understanding of the energetics of shallow wetland ponds and of the trophic base for salamander larvae and other predators. Sampling included cores for benthic invertebrates and traps for emerging insects, as well as water samples for planktonic invertebrates. Sample processing is still underway, but results from the first year of sampling and an earlier study on planktonic production suggest that the benthos plays a dominant role. Benthic biomass, which is dominated by oligochaete worms and chironomid larvae, exceeds planktonic biomass by a factor of at least ten. Combined production of oligochaetes and chironomids (18 $\mathrm{g}$ dry mass $\left.\mathrm{m}^{-2} \mathrm{yr}^{-1}\right)$ is about three times the production of zooplankton.

In collaboration with the South Carolina Heritage Trust program, we expanded the context for understanding the distributions of microcrustaceans on the SRS by sampling 18 off-site Carolina bays and flatwoods ponds. Among the taxa that we have studied, calanoid copepods seem most responsive to geographic factors. A. E. DeBiase and Dr. T. E. Bowman of the Smithsonian Institution are describing a new species of calanoid copepod, tentatively named Diaptomus atomicus. This species is the most common calanoid copepod on the SRS, occurring in about a quarter of the Carolina bays and other wetland ponds. It has been absent from collections in similar habitats elsewhere in the state.

The sediments of Carolina bays on the SRS preserve only a sketchy record of their biotic histories. The record does include shells of diatoms and other siliceous microfossils. E. E. Gaiser, a doctoral student at the University of Georgia, surveyed the diatom floras of 26 ponds on the SRS. She has identified more than 100 taxa, and statistical analyses indicate that assemblage composition is sensitive to pond hydrology. She will apply these results to diagnose past environmental conditions using assemblages of fossil diatoms extracted from sediments of the bays.

Studies on other aspects of bay stratigraphy and archaeology are continuing in collaboration with the Savannah River Archaeological Research Program. Under the auspices of a contract from the Environmental Protection Agency, B. E. Taylor and D. Scott developed an individual-based computer model for population dynamics of the salamander Ambystoma opacum. The model will be used to assess sensitivity of the population to change in climate or land use. We maintained regular sampling at two temporary ponds for long-term studies on zooplankton dynamics.

\section{Recent Publications: Zooplankton}

Brooks, M. J., B. E. Taylor, J. A. Grant, and E. E. Gaiser. 1993. Upland wetlands investigation of PleistoceneHolocene environmental change on the SRS. In Annual Review of Cultural Resource Investigations by the Savannah River Archaeological Research Program. Fiscal Year 1993. p. 27-44. South Carolina Institute of Archaeology and Anthropology, University of South Carolina, Columbia, SC. 
Boileau, M. G., and B. E. Taylor. Chance events, habitat age, and the genetic structure of pond populations. Archiv für Hydrobiologie (in press).

DeBiase, A. E., and B. E. Taylor. 1993. New occurrences of Eurytemora affinis and Epischura fluviatilis, freshwater copepods of the family Temoridae, in South Carolina. American Midland Naturalist 130: 386-392.

Gaiser, E. E. and R. W. Bachmann. 1993. The ecology and taxonomy of epizoic diatoms on Cladocera. Limnology and Oceanography 38:628-637.

Gaiser, E. E. and R. W. Bachmann. 1994. Seasonality, substrate preference and attachment sites of epizoic diatoms on cladoceran zooplankton. Journal of Plankton Research 16:53-68.

Taylor, B. E., A. E. DeBiase, and D. L. Mahoney. 1993. Development of the zooplankton assemblage in a new cooling reservoir. Archiv für Hydrobiologie 128:129-148.

Taylor, B. E., and W. Gabriel. 1993. Optimal adult growth of Daphnia in a seasonal environment. Functional Ecology 7:513-521. 


\title{
Quality Assurance Program
}

\author{
D. R. Burrows
}

In 1992 the U.S. Department of Energy (DOE) approved SREL's first formal quality assurance program. The program, developed within the context of DOE quality requirements, deals exclusively with the quality of SREL research activities.

Over the past year, three formal internal assessments of SREL research were conducted, along with ten compliance inspections. Additionally; DOE Headquarters personnel performed an audit of environmental compliance at SREL and found the quality assurance program to be one of the Laboratory's strengths.

SREL has remained an active contributor to national standards initiatives for research and development quality assurance; these initiatives include ones sponsored by the ASQC, ASME, ANSI, and the EPA.

\section{Environmental Health and Safety Program}

W. J. Safter

The Savannah River Ecology Laboratory (SREL) is committed to providing a workplace that is free of recognized hazards and an environment where risks to the occupational safety and health of its personnel remain as low as is reasonably achievable. During the past year, an emphasis on personnel training and program assessment furthered the progress toward these goals.

Courses in first aid, cardiopulmonary resuscitation, sealed radioactive source control, boating safety, wilderness safety, X-ray safety, ergonomics, radiation safety, fume hood safety, personnel protective equipment, driver safety, hazard communication, Resource Conservation and Recovery Act (RCRA), new employee safety, and job specific safety were offered. Updated safety information and lessons learned were transmitted via the SREL newsletters (The Grapevine and The Grapeleaf), the University of Georgia safety newsletter (Flashes), official memoranda, and the SREL safety bulletin board.

Numerous environmental health and safety inspections, surveillances, assessments, and program evaluations were conducted in the areas of radiation safety, industrial hygiene, occupational safety; wild animal handling, and radioactive air and liquid effluent monitoring. There was also an independent external laboratory safety appraisal and an independent internal safety program evaluation. These assessments provided valuable information which has been used to strengthen the EH\&S program.

Additionally, several DOE orders were assessed, and all chemical hygiene plans and Project Safety Appraisal forms were reviewed. Several SRS site-wide programs were assessed against applicable DOE regulations, and proposals to effectively address the requirements were submitted.

SREL has remained an active contributor to national and international safety associations including the Health Physics Society, the Campus Safety Association, and the National Safety Council. 


\section{Recent Publication: Safety and Quality Assurance}

Burrows, D.R. 1993. Quality assurance invades the swamp (Quality assurance in a basic research organization). Quality Progress 26(12): 105-107. 


\section{B. WOOD STORK FORAGING AND BREEDING ECOLOGY}

The Wood Stork Program is a long-term study of a federally endangered bird species that forages in wetland habitats on the SRS. Observations were made to determine breeding success at the stork rookery near Millen, Georgia, in FY94. Feathers and carcasses were salvaged in the colony for future DNA research, and leg bands were attached to hatchling storks to determine their movement patterns. The Kathwood foraging ponds near Jackson, South Carolina, which were initiated in FY86, were monitored throughout the summer to document use of the ponds by wood storks. 


\section{SREL WOOD STORK PROGRAM}

\section{Wood Stork Foraging and Breeding Ecology}

A. L. Bryan, Jr. and I. L. Brisbin, Jr.

Wood Storks returned to the Birdsville Colony in lower numbers ( $\mathrm{N}=230$ nests) in 1994 than the previous two seasons (1993: 330 nests, 1992: 243 nests). The nearby Chew Mill Pond Colony increased to 65 nests in 1994, as compared to 44 nests in 1993. Both colonies experienced poor breeding success, fledging only $0.9 \pm 1.1(\mathrm{~N}=51$ nests $)$ and 0.7 $\pm 0.9(\mathrm{~N}=13$ nests) young per nest, respectively. Only $45 \%$ of the Birdsville nests and $38 \%$ of the Chew Mill Pond nests produced any fledglings at all. Low numbers of nest initiations at Birdsville and general poor breeding success at both sites can be attributed to regional weather patterns (dry winter/ very wet spring-summer) which probably resulted in extremely poor foraging conditions during the nestlings' peak period of food demand.

Wood Storks continued to use the Savannah River swamp system sporadically during the summer months. Storks were observed foraging in Carolina bays and other SRS wetlands throughout the summer. No storks were observed using the PAR Pond system or L-Lake in 1994, but a single stork was observed roosting on Pond B on July 25.

Storks were observed using the Kathwood foraging ponds during the entire period (7/05 - 8/14) the ponds were lowered. A maximum of 156 storks were observed in Pond 4 on July 11. Research initiated this season has documented that many Wood Storks are foraging nocturnally and that it is occasionally the period of peak foraging activity.

In a cooperative study with the Georgia Department of Natural Resources and the Florida Game and Freshwater Fish Commission, blood samples were collected from 136 stork nestlings in Georgia and Florida as part of a molecular genetic study examining population structure and inter-colony relatedness.

\section{Recent Publications: SREL Wood Stork Program}

Bryan, A. L., Jr. 1993. The Savannah River Ecology Laboratory Wood Stork Program: 1993 annual report. Unpublished report to DOE.

Bryan, A. L., Jr., and M. C. Coulter. Wood Stork use of the Kathwood foraging ponds: 1986-1993. The Savannah Wood Stork Symposium (in press).

Bryan, A. L., Jr., M. C. Coulter, and C. J. Pennycuick. Foraging strategies and energetic costs of foraging flights by breeding Wood Storks. Condor (in press).

Coulter, M. C. and A. L. Bryan, Jr. 1993. Foraging ecology of Wood Storks (Mycteria americana) in eastcentral Georgia. I. Characteristics of foraging sites. Colonial Waterbirds 16:59-70.

Coulter, M. C., and A. L. Bryan, Jr. The design and management of the Kathwood ponds: Artificial foraging ponds for Wood Storks from east-central Georgia. The Savannah Wood Stork Symposium (in press). 


\section{DEFENSE WASTE PROCESSING FACILITY}

Ecological studies related to Defense Waste Processing Facility (DWPF) construction continue to support commitments as specified in the Environmental Impact Statement (EIS) and in the DWPF Environmental Monitoring Plan. Following startup of the $D W P F$, these studies will provide a comparative database for determining environmental quality and impacts from DWPF operation. 


\section{ECOLOGICAL STUDIES RELATED TO THE CONSTRUCTION OF THE DEFENSE WASTE PROCESSING FACILITY (DWPF)}

\section{DWPF Construction and an Experiment in Mitigation \\ D. E. Scott, J. H. K. Pechmann, A. C. Chazal, and R. A. Estes}

Construction of the Defense Waste Processing Facility (DWPF) began in late 1983. Before construction, the 600-acre site contained a Carolina bay and the headwaters of a stream. SREL has conducted ecological studies to assess the impact of DWPF construction on these wetlands since FY79. In recent years emphasis has been placed on: 1) monitoring the water quality of peripheral streams that were impacted by DWPF construction, and 2) understanding the population dynamics of amphibian species so that human-induced population fluctuations can be separated from naturally occurring fluctuations.

Water quality monitoring was conducted monthly, with an emphasis on sampling after rainfall. Water samples were analyzed in the laboratory for turbidity, total suspended solids (TSS), specific conductance, and percent ash. These data were compared to data from previous years. In general, levels of TSS and turbidity continued to decline in FY93 and FY94 from high levels during the years of DWPF construction. The average level of TSS in McQueen's Branch (a small stream adjacent to S-Area) was lower than in all previous years of monitoring. Water quality measurements will continue in FY95.

When DWPF was built, an entire Carolina bay (Sun Bay) was eliminated. Because Carolina bays are important centers for biodiversity, especially of amphibians, SREL's research has focused on the amphibian community at a control site, Rainbow Bay (RB). Breeding populations of amphibians were censused daily at RB in FY94, and were compared to previous years. Numbers of amphibians breeding at $\mathrm{RB}$, and their reproductive success, varies tremendously from year to year. Amphibian population declines have been of great interest in scientific literature recently; 12 years of data for four species from RB were published in the journal Science in 1991 as an example of the extreme variability in amphibian breeding population sizes. Experiments were conducted at supplementary sites, in both aquatic and terrestrial habitats, to determine the importance of factors that drive these fluctuations. Experimental studies were initiated in FY94 to assess the impact of clear-cutting on the growth and survival of amphibians. The effects of forest management practices on amphibian populations are of particular interest.

Studies have shown that an undisturbed terrestrial buffer zone around bay wetlands is important, and that movement of amphibians among adjacent wetlands may promote long-term persistence of populations. Consequently, a 200-meter area around RB, which is connected to smaller buffer zones around two adjacent ponds (Bullfrog Pond and Pickerel Pond) was established as a DOE Research Set-Aside area in FY92.

Recent Publications: Ecological Studies Related to the Construction of the Defense Waste Processing Facility (DWPE)

Krenz, J. D. and D. E. Scott. 1994. Terrestrial courtship affects mating location in Ambystoma opacum. Herpetologica 50:46-50.

Pechmann, J. H. K. and H. M. Wilbur. 1994. Putting declining amphibian populations in perspective: Natural fluctuations and human impact. Herpetologica 50:65-84.

Scott, D. E. 1994. The effect of larval density or adult demographic traits in Ambystoma opacum. Ecology (in press). 


\section{ENVIRONMENTAL RISK ASSESSMENT}

This program is designed to determine the response of aquatic and terrestrial ecosystems to environmental perturbations caused by SRS operations. The following programs currently address specific stresses of concern on the SRS: (1) studies on fish use of natural and impacted aquatic habitats on the SRS including Upper Three Runs Creek and Fourmile Branch, and (2) investigations into the status (either endangered or threatened) of a mussel on the SRS. Technical information necessary for making environmental protection and natural resource management decisions pertinent to maintaining continued compliance with federal and state regulations is provided by these programs. 
Status of Elliptio Mussels on the Savannah River Site

M. E. Mulvey

Morphological and genetic characteristics of Elliptio species on the SRS have been summarized in a report, Species Status of Mill Creek Elliptio, SRO-NERP-22. Elliptio hepatica is the species designation given to the former Mill Creek Elliptio. In the streams of the SRS this species has a limited distribution and occurs in low numbers.

To clarify the status of Elliptio hepatica, we surveyed streams in all 42 counties of South Carolina. More than 400 locations were searched for mussels. Again, E. hepatica has a limited distribution, being found only in Aiken, Allendale, Bamberg and Barnwell counties. Where it was present, it was not abundant. Based on these data, E. hepatica is rare and potentially a species of special concern in South Carolina.

During the course of surveys of SRS streams and the Savannah River adjacent to the SRS, we identified populations of other mussel species which may be of concern on the SRS. The American Fisheries Society Endangered Species Committee (Williams et al. 1993) has provided status designations for freshwater mussels. Elliptio folliculata and E. producta are listed as species of special concern; populations of these mussels have been found in SRS streams or adjacent river areas. Toxolasma pullus is listed as threatened and has been recovered from the Savannah River adjacent to the SRS. No Elliptio fraterna, a species listed as endangered, have been found.

\section{Red-Cockaded Woodpecker Studies}

R. K. Chesser

The habitat of the red-cockaded woodpecker has become highly fragmented throughout its natural range. As a result, birds are concentrated in small populations with little or no migration among the populations. Therefore, random and deterministic processes may have considerable influence on the dynamics and viability of local populations. Restoration efforts of red-cockaded woodpecker populations on the SRS, instigated by the SRFS, face many difficulties because: (1) the small population size may result in rapid loss of genetic variation and rapid accumulation of inbreeding; (2) inbreeding may erode the viability and fertility of birds; (3) reintroduction of birds in order to restore genetic variation will not be effective over long periods of time; (4) random changes in adult numbers (demographic changes) and distributions will contribute to decline in population viability; (5) inability to maintain critical social structures may adversely affect population recovery, and; (6) competition with other, well established species, such as the southern flying squirrel (Glaucomys volans) may impede restoration efforts to establish large, viable populations of woodpeckers on the site.

The goals of this research program are to address each of these potential barriers to recovery of the red-cockaded woodpecker on the SRS. These studies include a wide variety of techniques including mathematical and computer modeling and empirical assessment of populations of potentially competing species. Before adequate models could be attempted, 
the mathematical constructs for the dynamics of population characteristics suitable for redcockaded woodpeckers had to be developed. Traditional models used in conservation biology do not incorporate spatial variance as a component. Models developed in this program are unique in that components for spatial variation are included and are shown to have a dramatic effect on changes in genetic diversity. Model development serves at least two purposes. Computer models can be used to predict the fate of population dynamics and gene diversity only if all of the functions and paradigms that affect the populations are understood clearly. Computer models can not lead to development of new paradigms. Mathematical models involve the formalization of paradigms and functions into quantitative form. Thus, mathematical models build the framework on which further computer modeling can be based.

This program has shown that there are many procedures that will serve to enhance the maintenance of genetic variation in red-cockaded woodpeckers that were heretofore not considered in conservation programs. For example, empirical assessments of flying squirrel populations have shown that squirrel populations are not limited by the availability of nesting sites as has been assumed. Placement of additional nest boxes in large tracts did not result in population growth. Flying squirrels apparently reside in different nesting areas over the year. Strong territoriality of squirrels and distributions and abundance of food resources apparently are more limiting to population growth than nest sites. These results indicate that competition between red-cockaded woodpeckers and flying squirrels for artificial nest boxes in transplant areas is probably not important in impeding the population growth of the woodpeckers. Therefore, expensive endeavors to eliminate flying squirrels from transplant areas of woodpeckers are likely having minimal impact.

\section{Recent Publications: Endangered Species}

Chesser, R. K. Synthesis. Science and the singular universe. In Spatial and Temporal Aspects of Population Processes, edited by O. E. Rhodes, Jr., R. K. Chesser, and M. H. Smith. University of Chicago Press. Chicago, IL (in press).

Chesser, R. K., O. E. Rhodes, Jr., D. W. Sugg, and A. F. Schnabel. 1993. Effective sizes for subdivided populations. Genetics 135:1221-1232.

Chesser, R. K., O. E. Rhodes, Jr., and M. H. Smith. Conservation. In Spatial and Temporal Aspects of Population Processes, edited by O. E. Rhodes, Jr., R. K. Chesser, and M. H. Smith. University of Chicago Press. Chicago, IL (in press).

Chesser, R. K. and D. W. Sugg. Toxicants as selective agents in population and community dynamics. In Quantitative Ecotoxicology: A Hierarchical Approach, edited by M. E. Newman and C. H. Jagoe. Lewis Publishers. Boca Raton, FL (in press).

Chesser, R. K., D. W. Sugg, O. E. Rhodes, Jr., J. M. Novak, and M. H. Smith. 1993. Evolution of mammalian social structure. Acta Theriologica 38, Suppl. 2:163-174.

Chesser, R. K., K. B. Willis, and N. E. Mathews. 1994. Impacts of toxicants on population dynamics and gene diversity in avian species. p. 171-188. In Proceedings of the Ninth Pellston Workshop: Wildlife Toxicology and Population Modeling. Integrated Studies of Agroecosystems, edited by R. J. Kendall and T. E. Lacher. SETAC Special Publication Series. Lewis Publishers. Boca Raton, FL.

Davis, G.M. and M. Mulvey. 1993. Species Status of the Mill Creek Elliptio. SRO-NERP-22. 58p. 
Mulvey, M. , J. M. Aho and O. E. Rhodes, Jr. 1994. Parasitism and white-tailed deer: timing and components of female reproduction. Oikos 70:177-182.

Mulvey, M. and S.M. Bandoni. 1994. Genetic variation in the M-line of Biomphalaria glabrata. Journal of Helminthological Society of Washington 61:103-108.

Rhodes, O. E., Jr. and R. K. Chesser. 1994. Genetic concepts for habitat conservation: The transfer and maintenance of genetic variation. Landscape and Urban Planning 28:55-62.

Rhodes, O. E., Jr., R. K. Chesser, and M. H. Smith (eds.). Spatial and Temporal Aspects of Population Processes. University of Chicago Press. Chicago, $\mathbb{L}$ (in press).

Williams, J. D and M. Mulvey. 1994. Essay 3A- Recognition of freshwater mussel taxa: A conservation challenge. In Principles of Conservation Biology, edited by G. K. Meffe and C. R. Carroll. p. 57-64. Sinauer Associates. Sunderland, MA. 


\section{D.2. FISH}

Ecology of a Representative Species; Population Genetic Structure of Selected Fishes; and Fluctuating Asymmetry Analysis in Selected Fishes

G. K. Meffe

\section{Ecology of a Representative Species}

Comparative study of growth and reproduction in the dusky shiner (Notropis cummingsae) indicates that populations in Fourmile Branch (recovering from years of thermal discharge) have more rapid growth and greater food resources than control populations in Upper Three Runs Creek. This is most likely because of higher productivity in this system (more sunlight), combined with broader resource availability because of fewer competing species. Reproductive output of these fish in Fourmile Branch also is much higher than that in Upper Three Runs Creek; this is principally because of the larger individual size in Fourmile Branch, but also remains higher when the size difference is factored out. The results of this work are being finalized and readied for publication.

A large fraction of the work with dusky shiners has been devoted to quantification of how storage lipid composition varies among populations, sexes, life stages, and seasons. Lipid levels of dusky shiners in Fourmile Branch tend to be higher than those in fish from Upper Three Runs Creek in both sexes at all life stages. There is a dramatic seasonal cycle of lipid accumulation and depletion associated with reproduction. Female dusky shiners in Fourmile Branch accumulate and store lipids through fall and winter, and lipids then are depleted during the summer spawning season. This pattern contrasts with Upper Three Runs fish, where there is no apparent accumulation of lipids until just before the spawning season, and where lipids are accumulated to a lesser extent than seen in the Fourmile Branch population.

Monthly collections of dusky shiners are being made from a similarly disturbed stream, Pen Branch, and two control streams, Meyers Branch and Salkahatchie River, in order to add replicate systems. Reproduction and lipid dynamics data are being collected from these samples to determine if the above described variation of dusky shiner life history patterns is consistent between disturbed and non-disturbed streams.

\section{Population Genetic Structure of Selected Fishes}

Data are being analyzed on the genetic structure of two species of SRS fishes, the dusky shiner (Notropis cummingsae) and the pirate perch (Aphredoderus sayanus). The very large data set now has been edited and cleared of errors and is being analyzed by the BIOSYS statistical package. We will determine genetic diversity and compare spatial genetic structures of these species, particularly with respect to possible influences of the effluent treatment facility on Upper Three Runs Creek.

\section{Fluctuating Asymmetry Analyses in Selected Fishes}

The same two species of fish from the genetics study are being analyzed for developmental disturbances by measuring deviations from bilateral symmetry (known as 
fluctuating asymmetry). Collaboration on data analysis is being pursued with Dr. Richard Strauss of Texas Tech University, an expert on morphological analyses.

\section{Stream Fish Communities}

Community collections began in 1994 and will be taken three times a year from sites established on two disturbed streams, Fourmile Branch and Pen Branch, and two control streams, Upper Three Runs and Meyers Branch. Preliminary analysis indicates large differences in fish densities between the disturbed and non-disturbed streams and possibly differences in condition and health of fishes. Collections and analysis continue. Within Pen Branch, effects of a U.S. Forest Service hardwood recovery effort on fish communities are being examined.

\section{Responses of Fish in Pond $\mathrm{C}$ to Acute and Chronic Thermal Stress} J. D. Congdon and R. U. Fischer

For about 30 years, bluegill have survived severe and unpredictable heating of Pond $\mathrm{C}$ near P-reactor. Bluegill escaped lethal temperatures by occupying one of four relatively small distinct refuge areas with cooler water. The refuges are characterized by reduced food availability, virtually no habitat structure, and increased interactions with predators. In response to demands of avoiding predators and foraging in an environment with reduced structure, we designed experiments to determine how the morphology and related performance traits of bluegills have changed in response to both direct and indirect effects of heated effluent.

To answer questions related to changes in morphology and performance traits, we collected approximately 150 bluegill from Pond C (heated site) and PAR Pond (normothermic site) during periods of reactor operations and from both sites two years after reactor shut down. In addition, 100 bluegill from Clarks Hill Reservoir were collected to be used in the morphological comparison as an extra control group. Twelve morphological traits (including length, depth and fin shape) were measured for each fish from all samples. Comparisons among sites revealed that overall body length increased and body depth decreased in Pond $\mathrm{C}$ bluegill as compared to those from PAR Pond and Clarks Hill. In addition, in Pond $\mathrm{C}$ fish the depth of both the pectoral and anal fins increased while fin lengths decreased when compared to those from PAR Pond and Clarks Hill. The morphological changes resulted in a more streamlined and fusiform-shaped fish in Pond C.

The morphological changes in Pond $\mathrm{C}$ bluegill are associated with greater burst and sustained speed compared to bluegill from PAR Pond. The combination of morphological and performance traits makes Pond $\mathrm{C}$ bluegill more effective at avoiding predators and foraging for prey in structurally reduced habitats.

We also continued to make collections from both sites for determination of life-history differences between Pond C and PAR Pond bluegill. The collections and subsequent analyses have shown that PAR Pond bluegill mature later and at a larger size as compared to bluegill from Pond C. We plan to continue sampling both sites to determine if genetic differences exist between Pond $\mathrm{C}$ and PAR Pond bluegill. 


\section{Mercury in PAR Pond sediments: Body burdens and sub-lethal impact in mosquitofish}

M. Mulvey and M. C. Newman

Mesocosm pools were established to assess bioaccumulation and potential impact of PAR Pond sediment mercury in the mosquitofish, Gambusia holbrooki. Mosquitofish were harvested following approximately 6 months maintenance in the mesocosms. Mercury accumulation will be determined for fish exposed to PAR Pond sediments and control fish. Harvest of fish was lower than expected and mesocosms have been re-established. These reestablished mesocosms will be used to continue to evaluate bioaccumulation and to determine long-term, sublethal effects. Genetic information for mosquitofish used to initiate the mesocosms and fish maintained in mesososms for four months was obtained using allozyme electrophoresis. These data will be used to evaluate the relationship between genetic variability in natural populations and population response to environmental stressors.

\section{Recent Publications: Fish}

Fischer, R. U. 1994. Morphological, physiological, and life history changes of bluegill sunfish in response to thermal stress. Ph.D. Dissertation, the University of South Carolina.

Keklak, M . M., M. C. Newman and M. Mulvey. 1994. Enhanced uranium tolerance of an exposed population of eastern mosquitofish (Gambusia holbrooki Girard 1859). Archives of Environmental Contamination and Toxicology 27:20-24.

Mulvey, M., G. P. Keller and G. K. Meffe. Single- and multiple-locus genotypes and life history responses of Gambusia holbrooki reared at two temperatures. Evolution (in press).

Newman, M. C., M. Mulvey, A. Beeby, R. W. Hurst and L. Richmond. Snail (Helix aspersa) exposure history and possible adaptation to lead as reflected in shell composition. Archives of Environmental Contamination and Toxicology (in press). 


\section{D.3. ASH BASIN STUDIES}

\section{Sub-lethal Effects of Toxicants on Organisms Occupying Coal Ash Basins and Nearby Areas on the SRS}

J. D. Congdon, R. D. Nagle, and C. Salice

Coal-powered plants produce electricity and steam for the SRS, and the resulting coal fly ash is stored in basins on the site. Although coal fly ash is not considered a hazardous waste, some constituents of the ash may be of environmental concern. Some metals and other contaminants leach into aquatic habitats adjacent to coal piles. The contaminants subsequently may be taken up by plants and animals. Bioaccumulation of some trace elements may cause sub-lethal effects that are expressed at both the individual and population levels. At the individual level, organisms with chronic exposure to pollutants may accumulate metals at levels that, 1) cause death, 2) disrupt physiological processes, or 3) impair reproduction. In addition, accumulation of metals may also directly affect offspring during development or indirectly through genetic damage to parents. A combination of changes in mortality and reproductive success of individuals in impacted populations results in changes in population dynamics in the short term, and possibly lifehistory changes in response to chronic exposure.

We conducted a study to determine if turtles that reside in the aquatic areas near the coal ash piles had higher levels of arsenic, cadmium, chromium, copper, manganese, nickel, and zinc in soma and reproductive tissue, compared to levels found at a reference site (Kathwood area). We found that, compared to turtles from the reference sites, turtles from the D-area ash basin area had elevated levels of arsenic, cadmium, chromium, copper, zinc, and nickel in their liver tissue, and elevated levels of arsenic in their muscle, bone, and shell tissue. The proportion of reproductive females captured at the ash basin area $(20 \%)$ was substantially reduced compared to the reference sites (56\%). In addition, we are presently attempting to assess any occurrence of genetic damage in turtles from the D-area ash basin utilizing DNA unwinding techniques.

We plan to continue collecting turtles and additional aquatic organisms to determine the levels of contaminant uptake in aquatic organisms in or near the ash basin. Additionally we will examine the effects of contaminants on the survival and growth of selected offspring. 


\section{E. ECOSYSTEM ALTERATION BY CHEMICAL POLLUTANTS}

These studies in biogeochemical ecology and water quality provide information necessary in making environmental protection and natural resource management decisions based on radioecological and chemical perturbations of various ecosystems. Studies focus on the fate and effect of pollutants that are released from SRS operations where baseline information is not available. Studies of these environmental transport processes should provide predictive capability to the Department of Energy. 


\title{
E.1. CYCLING OF COAL/FOSSIL FUEL CONTAMINANTS
}

\author{
Contaminants From Coal and Other Fossil Fuels \\ D. C. Adriano
}

A major goal of this program has been to investigate the release and biogeochemical cycling of contaminants from coal piles and ash basins, particularly as they relate to potential contamination of soils, surface waters, and ground waters. Data have been generated and analyzed as to the extent of contamination in soil, in ground waters and adjacent vegetated areas. It is now known that runoff effluents from coal piles at the SRS, particularly in the D-Area, could contaminate groundwaters. In addition, the leachate effluents from the ash basin/coal reject landfill also can contaminate the ground water as well as create an environment that is unfavorable for the establishment of native vegetation.

Recently, efforts have focused on evaluating the potential benefits of using fly ash as a composting constituent. This material could be used as a soil amendment on degraded lands, such as borrow pits on the SRS, and in plant nurseries. Efforts also will be directed toward remediating stressed vegetation areas in D-Area. This may involve manipulation of chemical properties of the soil substrate to be able to sustain plant growth. Five coal-burning power stations on the SRS provide excellent field sites for this research, which currently involves collaborative efforts with the Savannah River Forest Service.

A new field study was initiated in the spring of 1992 to study the feasibility of mixing fly ash with organic matter (chicken manure) as a soil amendment. The rationale for using the manure was to enhance the fertilization potential of the fly ash because this material is known to be low in major plant nutrients, except potassium. A native shrub, beauty berry (Callicarpa americana), was planted. This species also provides a suitable food for wildlife. Field data indicate that the mixture of fly ash and chicken manure enhance the biomass production of the shrub apparently due to increased soil fertility provided by the organic matter from the manure.

A study was initiated in July 1992 involving the application of high tonnages of fly ash on a turf farm. Approximately $10 \mathrm{~cm}$ of fly ash were placed on the surface in test trials. The focus is on the effect of this material on soil-plant-water relations and groundwater quality. Field data indicate that even high tonnages of the fly ash apparently have not been detrimental to groundwater quality. Shallow monitoring wells that assess the impact of high application rates on groundwater quality are providing quarterly samples for a risk assessment. Centipede turf is now being grown, and even at the highest rate of $10 \mathrm{~cm}$ applied on the surface did not prove too detrimental in the establishment of the grass. Research will continue to evaluate the effect of high application rates on the soil physical properties, including infiltration rate, soil temperature, bulk density and other properties. 


\section{Environmental Chemistry of Fossil-Fuel Derived Organic Contaminants}

G. L. Mills and G. Voos

Petroleum hydrocarbons are among the most prevalent contaminants at DOE sites. At the SRS, hydrocarbon contamination has resulted from the use of various petroleum fuels (e.g. kerosene, gasoline, diesel fuel) and lubricating oils (e.g., machine oil, crankcase oil). Although several strategies are likely to be employed in the restoration of SRS environments contaminated with petroleum derived hydrocarbons, bioremediation is generally the preferred approach. A landfarm treatment facility has been constructed in D-area by WSRC to bioremediate oil-contaminated soils excavated from the SRS and will operate in an experimental phase for 2 years. However, in some cases excavation of contaminated soil may be either impracticalor costs may be prohibitive. For example, the area of contamination may be extensive or some subsurface plumes may be inaccessible. In such cases, in situ bioremediation is generally the most promising remediation strategy.

One of the difficulties currently faced in evaluating the effectiveness of various treatments used to facilitate in-situ bioremediation is distinguishing microbial degradation from physical and chemical processes which modify hydrocarbons in the environment. The lack of well established analytical methods for the quantitative determination of the amount of biodegradation that has occurred has hindered the application of this technology. Laboratory studies have shown that straight-chained hydrocarbons are microbially degraded faster than branched-chained hydrocarbons which in turn are degraded faster than alicyclic compounds. This observation has led to the concept that the ratio of selected hydrocarbons can be used as a marker index by which degradation can be measured. In a recent study, molecular markers were used to evaluate the amount of biological degradation in fertilized and untreated beaches contaminated with Alaskan crude oil in Prince William Sound. The results from this study indicated that selected hopane compounds (pentacyclic triterpanes) when employed as a normalizing index were the best indicator of the amount of biological degradation of the oil. However, hopanes are not present in refined petroleum products which are contaminants at the SRS, and other markers need to be identified. Previous work conducted in our laboratory has identified dicyclic, diterpenoid hydrocarbons in samples collected from a diesel contaminant plume in the Central Shops Area. Since these compounds are structurally similar to the hopanes, they should serve as effective markers for assessing in situ biodegradation of hydrocarbons derived from refined petroleum products.

The specific objectives of this research are:

- Determine if terpenoid hydrocarbons are effective markers for measuring the biological degradation of petroleum derived hydrocarbons.

- Develop analytical protocols for the rapid, accurate, and precise determination of diterpenoid hydrocarbons in petroleum contaminated soils.

- Evaluate the quantitative and qualitative differences in the assemblage of diterpenoid hydrocarbons in various refined fuel and lubricating oils which are present in contaminated soils on the SRS.

Our studies on the application of organic molecular markers for the assessment of microbial degradation of petroleum contaminants have focused on refining the analytical methods for dicyclic, diterpenoid hydrocarbons. Our previous results indicated that the ratio 
of these terpanes to $\mathrm{C}_{17}$ and $\mathrm{C}_{18}$ straight-chained hydrocarbons were a useful diagnostic tool for assessing microbial degradation. However, identifying and quantifying these compounds in a complex hydrocarbon mixture are difficult. We have evaluated the use of a molecular sieve (silica gel with a $0.5 \mathrm{~nm}$ pore size) and urea adduction to separate the alicyclic and highly branched alkanes from other hydrocarbons prior to HRGC-MS analysis. Although some separation was achieved using the molecular sieve, it was not complete and significant loss of some alicyclic terpenoid compound was observed. Problems were also encountered in the use of urea adduction. Thus, we concluded that the additional time required during the sample work-up for these technique was not warranted. We have now developed procedures for quantifying the terpenoid hydrocarbons on the GC-MS in the selected ion monitoring mode using internal standards and determining relative response factors. This circumvents the need for any further prior separation of hydrocarbon compound classes.

We have constructed a system of soil mesocosms to evaluate optimum conditions for the ex situ biodegradation of soil contaminated with diesel oil. The mesocosm system consists of 9 tanks each of which contains about $3000 \mathrm{~kg}$ of soil. The systems are outside and serve as a model for the land farm treatment at the WSRC SOILs facility. We have recently completed our first study which compared an oleophilic fertilizer and a standard inorganic amendment. The surfactant-fertilizer mixture, Inipol EAP22, is designed to associate with the oil and release nitrogen and phosphorous slowly. Soil samples were collected and hydrocarbon and microbial analyses conducted on days $1,2,4,8,14,33$, and 64 following fertilizer addition. A study employing microcosm chambers, each containing $1 \mathrm{~kg}$ of contaminated soil, was conducted concurrently to examine the effects of scale on the model systems. Sample collection and analysis are complete and the data are currently being processed and evaluated.

\section{Recent Publications: Cycling of Coal/Fossil Fuel Contaminants}

Carlson, C. L. and C. A. Carlson. 1994. Impacts of coal pile leachate on a forested wetland in South Carolina. Water, Air, and Soil Pollution 72:89-109.

Dosskey, M. G. and D. C. Adriano. 1993. Trace element toxicity in VA mycorrhizal cucumber grown on weathered coal fly ash. Soil Biology and Biochemistry 25:1547-1552.

Keefer, R. F. and K. S. Sajwan (eds.) 1993. Trace Elements in Coal and Coal Combustion Residues. Lewis Publishers, Boca Raton, FL. 308pp.

Martin, H. W. More on beautyberry. Palmetto (in press).

Menon, M. P., K. S. Sajwan, G. S. Ghuman, J. James, and K. Chandra. 1993. Chapter 12. Elements in coal and coal ash residues and their potential for agricultural crops. In Trace Elements in Coal and Coal Combustion Residues, edited by R. F. Keefer and K. S. Sajwan. p. 259-287. Lewis Publishers, Inc. Boca Raton, FL.

Sandhu, S. S., G. L. Mills, and K. S. Sajwan. 1993. Chapter 8. Leachability of Ni, Cd, Cr. and As from coal ash impoundments of different ages on the Savannah River Site. In Trace Elements in Coal and Coal Combustion Residues, edited by R. F. Keefer and K. S. Sajwan. p. 165-182. Lewis Publishers, Inc. Boca Raton, FL. 


\section{E.2. RADIONUCLIDE CYCLING IN POND B}

\section{Functional Processes in Vertebrates}

I. L. Brisbin, Jr.

Laboratory studies continued on the growth and development of American alligators maintained on a dry formulated ration and/or provided with radiocesium-contaminated bass from the Pond B reservoir as a sole source of food. Semi-annual weights and measurements of these animals indicate continuing, but declining growth of the animals maintained on the formulated ration. The alligators receiving contaminated Pond B bass as food continue to increase their radiocesium body burdens but at a diminishing rate. In the case of one individual, the radiocesium body burden had earlier appeared to be approaching an asymptote, but still continued to increase during the past year, making this the longest continual uptake event ever documented for any animal ingesting this contaminant.

Construction was completed on a holding coop and release pen for sentinel bantam chickens. Birds were placed in this facility in late February 1994 and given free access to the contaminated PAR Pond mudflats while uncontaminated feed was also available to them in the coop. The birds were whole-body counted to determine radiocesium body burdens at 40 50 day intervals. After 150 days of exposure, body burdens of radiocesium had leveled-off although only a few birds showed contamination levels that were above instrument detection limits. In mid-summer, the clean feed was removed and birds were forced to feed on scratch grains that were scattered directly on the mudflat. This change in feeding regime caused an increase in all of the birds' radiocesium burdens, with those of females exceeding those of males. This study is continuing to follow the increasing radiocesium levels in these birds, and these data are being analyzed for use in assessments of the use of such free-ranging poultry as possible sources of food protein in radionuclide contaminated habitats.

An invited paper describing waterfowl radioecological studies was presented at the XXI International Ornithological Congress in Vienna, Austria. Revisions were also completed on a manuscript prepared from a graduate thesis describing radiocesium uptake and contamination patterns in Pond B's resident nesting wood ducks and their eggs.

Annual night-eyeshine censuses continued to document the numbers of alligators using Pond $\mathrm{B}$. Census cruises determining the use of the reservoir by aquatic birds were also continued.

Data from a long-term study of the uptake of radiocesium by slider turtles introduced into enclosures in Pond B were combined with data on the equilibrium levels of this contaminant in the reservoir's free-living resident turtles of the same species. The combination of these data sets produced a manuscript which has now been submitted for publication in Ecology. In this paper, the Pond B turtle radiocesium data are used to evaluate the predictions of a temperature-based radionuclide uptake model for ectothermic vertebrates.

The annual trapping and whole-body counting of radiocesium in migratory waterfowl wintering on the PAR Pond CERCLA unit also was continued under the partial support of this program. 


\section{Recent Publications: Radionuclide Cycling in Pond B}

Brisbin, I. L., Jr. 1993. Birds as monitors of radionuclide contamination. In Birds as Monitors of Environmental Change, edited by R. W. Furness and J. J. D. Greenwood. p. 144-178. Chapman and Hall, London.

Brisbin, I. L., Jr. 1994. Chapter 17. Applications of a modified Richards sigmoid model to assess the uptake and effects of environmental contaminants upon birds. p. 161-170. In Proceedings of the Ninth Pellston Workshop: Wildlife Ecology and Population Modeling, edited by R. J. Kendall and T. E. Lacher, Jr. Lewis Publishers, Inc. Boca Raton, FL.

Kennamer, R. A., C. D. McCreedy, and I. L. Brisbin, Jr. 1993. Patterns of radiocesium contamination in eggs of free-ranging wood ducks. Journal of Wildlife Management 57:716-724. 


\section{E.3. SOIL/SEDIMENT REMEDIATION}

\section{Soil/Sediment Remediation at PAR Pond}

\section{C. Adriano}

This two-year old program was created by redirecting funds from the old Biobarrier Program. A field plot study was initiated in the fall of 1992 near the SREL boat dock at PAR Pond. The exposed lakebed sediment was prepared to simulate garden plots. This study was precipitated by previous dose assessments by Dr. F. W. Whicker indicating that ingestion of food products raised in this area by a hypothetical lake basin inhabitant would represent the greatest exposure risk. Hence, this study is primarily an evaluation of various remedial options to enhance the quality of the food chain. Various remedial measures that already have been tested widely, as well as potentially innovative ones, are being evaluated. The efficacy of the various techniques is to be measured using crop indicators. For the fall of 1992 collards and cabbages were grown and measured for ${ }^{137} \mathrm{Cs}$ activity. Subsequent cropping included kohlrabi, turnips, radish, corn, and okra. Data collected to date on collards, cabbages, kohlrabi, turnips, radish and corn indicate that providing clean soil cover on the contaminated sediment resulted in lower cesium uptake than for plants grown where no soil cover was provided. The other soil cover treatments (i.e., those with geo-textile fabric and a root biobarrier sandwich between the clean soil cover and the contaminated sediment) produced even lower cesium uptake than just the plain soil cover. All the treatments involving the soil cover technique produced concentration ratios that are on or below the NCRP guideline value of 0.12 . The other techniques being tested, i.e., high $\mathrm{K}$ fertilizer application and zeolite addition, resulted in some diminution of cesium uptake, but they were not quite as effective as the clean soil cover techniques. The project will continue as long as the lake is not refilled.

\section{Recent Publications: Soil/Sediment Remediation}

Adriano, D. C., J. Albright, F. W. Whicker, and I. K. Iskandar. Remediation of metal and radionuclidecontaminated soil. Special volume from the Second International Conference on the Biogeochemistry of Trace Elements, Remediation of Metal Contaminated Soils. Applied Science Publishers, London (in press).

Adriano, D. C. and M. A. Elrashidi. Interactions of contaminants with soil components and environmental restoration. In Conference Proceedings of the International Soil Science Society, International Soil Science Society. 


\section{E.4. ENVIRONMENTAL GEOCHEMISTRY AND TOXICOLOGY OF URANIUM}

\section{Environmental Geochemistry of Uranium}

P. M. Bertsch

The Lost Lake, Tim's Branch (TB), and Steeds Pond regions of the Upper Three Runs Creek watershed have received considerable amounts of $\mathrm{U}, \mathrm{Ni}, \mathrm{Al}, \mathrm{Cr}$, and $\mathrm{Cu}$ from the M-Area fabrication facilities, which are largely immobilized in the surrounding soils and stream sediments. There is concern as to the potential impact of these metals on aquatic biota within the Tim's Branch system and the potential for transport of these metals to Upper Three Runs Creek (UTRC) which empties into the Savannah River. This research program was initiated with the objectives of examining the distribution, fate, and mobilization potential of $U$ and other introduced metals within and from contaminated sediments.

The extent of remobilization of uranium from contaminated sediments adjacent to Tims Branch stream during episodic rain events was investigated to determine the amount of $U$ that could be mobilized with increased sediment load delivered to the stream. Four storms were collected during the course of this study: $23 \mathrm{March}, 26 \mathrm{March}, 28 \mathrm{June}$, and 17 September 1993. The storms varied in intensity and duration, resulting in a range of rainfall conditions for comparison. Episodic rain events of sufficient intensity can readily disrupt soil aggregates and increase clay dispersion, especially during the high intensity, short duration events common to the Southeast during summer months. In addition, information on the solid phase associations of $U$ in floodplain and suspended sediments was assessed by an eight-step sequential extraction procedure to gauge $U$ chemical lability and its propensity for transport. If $U$ is concentrated in the easily dispersible or water dispersible clay (WDC) fraction of the floodplain sediments, then the amount of $U$ transported during storm events could be significantly greater than estimated based on bulk sediment concentration. WDC fractions of the floodplain sediments were collected and compared to the stream suspended sediments transported during storms to determine their relationship.

Mass flux estimates determined from base flow measurements potentially underestimate the amount of $\mathrm{U}$ transported from contaminated terrestrial sources to surface water systems. During the storm events, approximately 1,457 to $2,838 \%$ more U was mobilized to Upper Three Runs Creek (UTRC) relative to base flow calculations. The bulk of the $U$ associated with the suspended sediment load was found to be in chemically labile forms, predominantly as acid soluble (specifically adsorbed), $\mathrm{MnO}_{2}$ occluded, and organically-bound phases. This implies that the $U$ associated with these sediments may be available to the environment under a range of conditions that may vary temporally within a stream or depositional environment (e.g., EC, Eh, and pH). Sequential extractions of the floodplain sediments demonstrated that the $U$ was also primarily associated with chemically labile forms, but in different proportions to those found for the suspended sediments. More $U$ was associated with the organically bound phases in the floodplain sediments compared to the specifically sorbed and $\mathrm{MnO}_{2}$ associated phases. The water dispersible fraction of floodplain sediments was very similar 
to the suspended sediments in terms of mineralogical characterization and $U$ fractionation. The strong relationship between the suspended sediments and the WDC fraction of the floodplain soils suggests that U-rich fine particles are preferentially eroded from the exposed floodplain soils during episodic events and transported in the stream in chemically labile forms.

\section{Toxicology of Uranium}

\section{M.C. Newman}

A manuscript describing enhanced tolerance to uranium in a Steeds Pond population of mosquitofish and an abrupt shift in allele frequencies in mosquitofish sampled in the region of Steeds Pond was published in the Archives of Environmental Contamination and Toxicology. The question of whether the observed shift in allele frequencies was a consequence of toxic effect or a natural genetic bottleneck remained unanswered. However, the higher tolerance of fish derived from Steeds Pond populations relative to a Risher Pond population suggested that a toxic impact may be responsible.

Behaviors of benthic molluscs were assessed as sublethal indicators of Steeds Pond sediment quality. Sediments from Steeds Pond, clean sediment (negative control), and the D-Area ash basin sediment (positive control) were used in these assays of sediment preference and movement. There were no significant differences between molluscan behaviors in the clean sediment and sediment from Steeds Pond. Computer simulations indicated that the differences in clam movement between clean sediments and ash-contaminated sediments would not result in a significant avoidance of contaminated patches in a field setting.

Bacterial bioluminescence assays $\left(\right.$ Microtox $^{\circledR}$ ) also indicated no significant effect of sediment- or water column-associated metals. Predictive models describing relative toxicities of divalent metals were developed based on metal coordination chemistries. Predictive models of metal interactions were also developed in a similar approach.

\section{Recent Publications: Environmental Geochemistry and Toxicology of Uranium}

Bertsch, P. M., D. B. Hunter, S. R. Sutton, S. Bajt, and M. L. Rivers. 1994. In situ chemical speciation of uranium in soils and sediments by micro $\mathrm{x}$-ray absorption spectroscopy. Environmental Science and Technology 28(5):980-984.

Batson, V. L. 1994. Surface water transport and distribution of uranium in contaminated sediments near a nuclear weapons processing facility. M.S. Thesis. Texas A\&M University.

Keklak, M.M., M.C. Newman, and M. Mulvey. 1994. Enhanced uranium tolerance of an exposed population of the eastern mosquitofish (Gambusia holbrooki Girard 1859). Archives of Environmental Contamination and Toxicology 27: 20-24.

McCloskey, J.T. and M.C. Newman. Asiatic clam (Corbicula fluminea) and viviparid snail (Campeloma decisum) sediment preference as a sublethal response to low level metal contamination. Archives of Environmental Contamination and Toxicology (in press). 
McCloskey, J.T., M.C. Newman, and P.M. Dixon. Effect of metal contaminated sediment on the distribution of the asiatic clam, Corbicula fluminea populations. Archives of Environmental Contamination and Toxicology (in press). 


\section{F. WETLAND SYSTEMS}

This research documents the early recovery of wetland floodplain ecosystems from the effects of thermal and other discharges from SRS operations. Emphasis is on vegetation establishment physiological tolerances, and natural development of plant communities, on experimental approaches to enhance the rate of succession in highly disturbed floodplain forests, and on environmental transport of contaminants. In addition, recovery of the lower food chain in altered stream systems is being documented and compared with in-stream and floodplain communities in Upper Three Runs Creek. Research is directed toward recovery of both ecosystem structure and processes. This information will allow prediction of stream recovery rates and will also serve as a baseline for prediction of contaminant movement in SRS streams. 


\section{Inundation and Salinity Stress on Wetland Woody Species K. W. McLeod, J. K. McCarron, and W. H. Conner ${ }^{1}$}

Over the past several years, additional aspects have been added to this series of experiments. The responses to chronic and acute exposures of increased salinity and inundation have been observed in 6 additional species (button bush, Cephalanthus occidentalis; swamp tupelo, Nyssa sylvatica var. biflora; overcup oak, Quercus lyrata; swamp chestnut oak, $Q$. michauxii; water oak, $Q$. nigra; Nuttall oak, $Q$. nuttallii). For bald cypress (Taxodium distichum), the influence of age and consequent increase in size have also been examined over the past two growing seasons.

In the first experiment, examining the response of button bush and swamp tupelo, the latter species was surprisingly intolerant of inundation, regardless of salinity. In the second experiment, examining the response of the oak species, Nuttall oak was most tolerant of inundation. None of the oak species were tolerant of chronic saline inundation (either 2 or $6 \mathrm{ppt}$ ) and died before the end of the growing season. Even watering the seedlings with water of $6 \mathrm{ppt}$ salinity greatly reduced growth and survival of all four oak species. Hence, 5 of the 6 species did not tolerate the increased chronic saline inundation that lowland coastal forests might experience as a result of sea level rise or subsidence.

The response of bald cypress is very important since it is one of the most common woody species in the coastal forests. From the results of the first year of these studies, it was observed that chronic $10 \mathrm{ppt}$ saline inundation killed first year seedlings of bald cypress during that first growing season. Short term, acute exposure (48 hours) to $30 \mathrm{ppt}$ saline inundation also reduced photosynthetic rates. Results from the first year's exposure of 4 different ages of bald cypress saplings were inconclusive regarding the importance of age, since very little overall response was observed. This was probably due to the additional saline water being added to saplings which were already inundated. During the 48-hour exposure, the saline water did not have ample time to diffuse into the rhizosphere of the saplings and hence no impact was observed.

During the past growing season, prior to the acute exposure the soil in an additional group of saplings was allowed to partially dry, following long-term inundation, so that the saline water would rapidly enter the rhizosphere of the saplings. In this situation, the bald cypress saplings rapidly began to wilt, indicating water absorption or translocation difficulties, and in less than one week had shown browning of the foliage from the top to the bottom of the plants, regardless of the age or size of the saplings. Another group of saplings, which was treated similar to the previous year's situation (i.e. had not been dried down prior to acute exposure of 30 ppt saline inundation) showed very little visual response, similar to that observed in the previous year.

Since the acute exposures were used to mimic the response that might be observed with the storm surge of a hurricane, it is interesting that the increased rainfall which normally would precede the arrival of a hurricane might actually afford some protection for the vegetation from the saline overland storm surge. This protection would be effective in areas in which the storm surge would drain off relatively rapidly, but probably

'Belle Baruch Forest Science Institute, Clemson University, Georgetown, SC 
not be effective in other depressional areas where the saline storm surge would eventually percolate into the soil.

\title{
Natural Regeneration in Floodplain Forests
}

\author{
R. R. Sharitz, R. H. Jones, and P. M. Dixon
}

Long-term studies of the dynamics of wetland forests and the effects of hydrologic conditions on the recruitment and growth of woody species are continuing. Of special concern are the potential effects of altered hydrologic regimes on natural regeneration in these wetland forests. A detailed examination of seedling establishment in four forests on the SRS that represent different stream sizes and flooding frequencies (frequently and infrequently flooded sites in the floodplains of the Savannah River [large river] and Upper Three Runs Creek [small river]) have shown that many elements of natural tree regeneration are similar from forest to forest and across a broad range of environments. The most consistent patterns were: (1) more seeds and germinants for smaller seeded species; (2) greater survival rates for earlier germinants within a growing season; (3) increased survival rates for seedlings during the first several years after germination; and (4) slow growth of seedlings resulting in the establishment of dense understory seedling pools.

Shade and flood tolerance rankings were not strong predictors of seedling survival during the first growing season after germination, however, in subsequent years seedling survival appears to be increasingly linked to the ability to withstand flooding and deep shade. Seedling survival during the first growing season was significantly affected by site and site-species interaction effects. Weaker but still significant site effects were found for survival in subsequent years. Flooding appears to contribute to some of the differences in regeneration among the sites, yet the precise effects of flooding on seedling survival are hard to discern. Responses to flooding depend on the species, life stage, size and vigor of the tree seedlings as well as the type, timing and duration of the flood. Understanding the influences of flooding may be particularly important in view of the consistent and strong pattern of greater long-term survival for early germinants. Floods are more frequent in the early part of the growing season in southeastern U.S. floodplain ecosystems. Thus, early germination may have both costs and benefits.

At each of the forest sites, species composition of the seedling pools differed from that of the overstory forest. This suggests that species composition of the forest will change in the future. However, the replacement of upper canopy trees following a disturbance is a process that is only partially influenced by the composition of the predisturbance seedling pools. Understory saplings and sprouts from the root systems of damaged trees are also important as sources of new canopy trees. Of concern in the two forest sites on the large river floodplain is the very low density of saplings in the understory, suggesting that occasional, but catastrophic, floods may limit long-term seedling survival and growth to reach these larger juvenile size classes. 


\section{Monitoring Rare Plants and Modelling Historical Carolina Bay Hydrology}

P. M. Dixon

Populations of two rare plant species, Echinacea laevigata and Croton elliottii, have been monitored on the SRS. Echinacea laevigata was listed as a federally endangered plant in December 1992. Since 1989, the one Echinacea population on the SRS has been declining slowly, with few plants flowering each year. This population is biologically unusual in being one of three Coastal Plain populations. Most of the known Echinacea populations are found on geologically altered rocks in the Piedmont. When the species was placed on the Federal Endangered Species List, the Coastal Plain populations were considered separately from the remaining populations because they were considered to have been introduced. Subsequently, more Coastal Plain populations, including a second SRS location, have been discovered. The original SRS population from E. laevigata continues to decline. In the September 1993 survey there were 175 plants alive, down from 209 plants in summer 1992.

No Croton elliottii were found in the October 1993 survey because the water levels in its habitat, Carolina bays, were extremely high. The $10 \mathrm{~m} \mathrm{X} \mathrm{10m} \mathrm{permanent}$ plots used to census Croton were established during the 1989-1990 drought. Water levels were lower during summer 1994, and Croton has reestablished in Woodward Bay. This population will be counted in October 1994.

\section{Vegetation Dynamics in Carolina Bay Wetlands Associated with Cycles of Drought and Precipitation}

L. K. Kirkman and R. R. Sharitz

Dominant vegetation patterns in four herbaceous dominated (depression meadow) Carolina bay wetlands were mapped before, during and following a record 10-year drought from color infrared and natural color photography. Vegetation patterns in the depressional wetlands shifted spatially. During the drought upland species encroached along the margins as conditions became dry. As the soil surface was exposed, aquatic plant species declined. Changes in abundances and relocation of the dominant perennial grasses, Panicum hemitomom, Manisurus rugosa and Leersia hexandra appear to be indicators of hydrologic change. The relative size and corresponding slope of the depression appear to influence the patterns of change observed during a dry period. Following the drought as the bays refilled with water, these grass species again shifted spatially and floating-leaved aquatic plants again became dominant in the deeper areas.

Cyclical changes of the vegetation associated with changing precipitation patterns appear to be common in these shallow wetlands. Mechanisms regulating dominance in vegetation under most hydrologic conditions include the physiological responses of common species to inundated and dry conditions and to disturbances during drought. During extremes of the hydrologic regime (i.e., very wet or very dry conditions), recruitment from the seed bank becomes a more significant factor influencing vegetation change. Conservation management of these intermittently-inundated wetlands should incorporate techniques to foster maintenance of endemic species richness and the 
recruitment of rare species. Episodic disturbances during periods of drought may be desirable to partially remove aggressive perennial species and thus allow recruitment of less common species.

\section{Recent Publications: Wetlands}

Hardegree, W. S., D. B. Wenner, J. F. Dowd, and K. W. McLeod. Using ${ }^{18} \mathrm{O} /{ }^{16} \mathrm{O}$ data to delineate backwater influence in wetlands. Wetland Ecology and Management (in press).

Jones, R. H., D. S. Segal, and R. R. Sharitz. 1994. Cation dynamics in bottomland forest litter. American Midland Naturalist 131:248-256.

Jones, R. H., R. R. Sharitz, P. M. Dixon, D. S. Segal, and R. L. Schneider. 1994. Woody plant regeneration in four floodplain forests. Ecological Monographs 64:345-367.

Jones, R. H., R. R. Sharitz, S. M. James, and P. M. Dixon. Tree population dynamics in seven South Carolina mixed-species forests. Bulletin of the Torrey Botanical Club (in press).

Keeland, B. D. and R. R. Sharitz. 1993. Accuracy of tree growth measurements using dendrometer bands. Canadian Journal of Forest Research 23:2454-2457.

Kirkman, L. K. and R. R. Sharitz. 1994. Vegetation disturbance and maintenance of species diversity in intermittently flooded Carolina bays in South Carolina. Ecological Applications 4:177-188.

Sharitz, R. R., M. R. Vaitkus, and A. E. Cook. 1992. Hurricane damage to an old-growth floodplain forest in the southeast. Seventh Biennial Southern Silvicultural Research Conference, Mobile, AL 1992:203-210.

Young, P. J., J. P. Megonigal, R. R. Sharitz, and F. P. Day. 1993. False ring formation of baldcypress (Taxodium distichum) saplings under two flooding regimes. Wetlands 13:293-298.

Young, P. J., B. D. Keeland, and R. R. Sharitz. Baldcypress growth response to altered hydrology. American Midland Naturalist (in press). 


\section{Surface and Subsurface Invertebrate Assemblages J V. McArthur}

We completed the installation of sampling tubes in both Meyers Branch and Tinker Creek watersheds that allow us to sample hyporheic organisms. We collected several taxa that are new records for South Carolina and increased our understanding of the dimensions and composition of the subsurface aquatic habitat. We have found an isopod that has been identified from only one previous record in southern Europe. This finding generates several new questions about biogeography, stability of underground habitats and speciation processes. Clearly, anthropogenic disturbances may affect subsurface species assemblages, and the effect on ecosystems of such disturbance is completely unknown to science. In addition we have begun studies designed to compare and contrast various sampling techniques. A new graduate student will evaluate these sampling methods in both disturbed/recovering systems (Four Mile Creek) and undisturbed streams (Meyers Branch and Upper Three Runs Creek).

We completed a survey of Meyers Branch to document the movement of the asiatic clam Corbicula fluminea. Several years ago we found that this clam had moved up from Steel Creek into Meyers Branch. At that time the distribution was limited, but today this clam can be found almost the full length of Meyers Branch. The rapid movement is important and any potential negative impacts need to be considered with respect to the native bivalve fauna in other streams on the site.

After considering the uniqueness of Upper Three Runs Creek in the context of species richness/diversity/endemism we have completed an analytical/theoretical paper to erect various reasons for this observation. This work is primarily literature based but has shown that Upper Three Runs Creek is among the most unique streams in the world. This work will be of great value in determining the best management strategy for this resource.

\section{Recent Publications: Lower Food Chain}

Floyd, M. A. 1992. The biology and distribution of Oecetis larvae in North America (Trichoptera: Leptoceridae). p. 87-91. In Proceedings of the 7th International Symposium on Trichoptera. Universal Book Services.

Rader, R. B. and J V. McArthur. The relative importance of refugia in determining the drift and habitat selection of predacious stoneflies in a sandy-bottom stream. Oecologia (in press).

Rader, R. B., J V. McArthur, and J. M. Aho. 1994. Relative importance of mechanisms determining decomposition in a southeastern blackwater stream. The American Midland Naturalist 132:19-31. 


\section{F.3. ENVIRONMENTAL TRANSPORT PROCESSES}

\section{Physicochemical Factors Regulating Facilitated Contaminant Transport P. M. Bertsch}

The chemical speciation and solid phase partitioning of metals and contaminant organics control their mobility in the environment and their bioavailability and toxicity. Our research over the past year has continued to examine both fundamental and more applied aspects of chemical speciation and the associated implications for contaminant mobility and toxicity, with special emphasis on physicochemical factors involved in facilitated transport of contaminants.

A highly acidic aqueous waste containing metals was released into unlined seepage basins in F- and H-Areas between 1955 and 1988, resulting in the contamination of the underlying aquifer. Trace levels of $\mathrm{Pu}, \mathrm{Am}, \mathrm{Cm}$, and $\mathrm{U}$ and more elevated levels of the transition metals $\mathrm{Cr}, \mathrm{Ni}, \mathrm{Cu}$, and $\mathrm{Pb}$ in an acidic plume have been traveling through a surface aquifer underlying the Savannah River Site at rates appreciably greater than anticipated. The objective of this study was to determine the extent to which each of these actinides was associated with groundwater colloids, a potential cause for the apparent enhanced transport. Contaminated groundwater was recovered along a 1.02-km transect at approximately the rate of groundwater flow, passed though an ultrafiltration system, and then chemically characterized. The filterable ( $>500$ molecular weight) fraction of nuclides increased with reported nuclide distribution coefficients (Kd values): $\mathrm{Pu}>\mathrm{Th}>\mathrm{U}>\mathrm{Am}=\mathrm{Cm}>\mathrm{Ra}>$ tritium. The filterable fractions of the stronger-sorbing nuclides ( $\mathrm{Pu}$ and $\mathrm{Th}$ ) increased, whereas those of the weaker-sorbing nuclides $(\mathrm{Am}, \mathrm{Cm}$, and $\mathrm{Ra}$ ) generally decreased with increasing $\mathrm{pH}(3.4$ to 4.0$)$ and distance from the point source.

Uranium was equally divided between the dissolved and filterable fractions throughout the transect. At the farthest sampling point in the contaminant plume $(0.55$ $\mathrm{km}$ ), all the $\mathrm{Pu}$ and $\mathrm{Th}$ and none of the $\mathrm{Am}$ and $\mathrm{Cm}$ were in the filterable fraction. Plutonium appears to have a much greater potential than $\mathrm{Am}$ or $\mathrm{Cm}$ for moving through the study site in association with mobile colloids. However, $\mathrm{Am}$ and $\mathrm{Cm}$ pose a much greater likelihood than $\mathrm{Pu}$ of migrating through this system, because almost all of the $\mathrm{Pu}$, but relatively little of the $\mathrm{Am}$ and $\mathrm{Cm}$, were retained by the matrix.

Enhanced transport was attributed primarily to the poor cation-sorbing capacity of the aquifer matrix and the soluble nature of the metals in the acidic plume. Based on chemical equilibrium calculations of ground water ultrafiltrates which agreed with results from cationic and anionic resin-exchange experiments, over $90 \%$ of each contaminant metal $(\mathrm{Cr}, \mathrm{Ni}, \mathrm{Cu}, \mathrm{Cd}, \mathrm{Pb}$, and $\mathrm{U}$ ) existed in cationic forms in the aquifer either as soluble metals or as sorbates associated with positively charged ground water colloids. These cationic species were not retained by the aquifer because the $\mathrm{pH}$ of the aquifer matrix was slightly below the measured point-of-zero-charge, indicating the variable charge sites on the mineral surfaces within the aquifer likely had a net positive charge. Contaminants were associated with recovered ground water colloids and this association increased with the $\mathrm{pH}$ of the system. However, mobile colloids would likely play only a small role in the transport of contaminants through this aquifer because of their relatively low concentration. 


\section{Recent Publications: Environmental Transport Processes}

Anderson, M.A., P.M. Bertsch, and L.W. Zelazny. 1993. Multicomponent transport through soil subjected to coal pile runoff under steady saturated flow. In Trace Metals in Coal and Coal Combustion Residues, edited by R.F. Keefer and K.S. Sajwan. p.137-164. Lewis Publishers,Inc. Boca Raton, FL.

Anderson, M. A. and P. M. Bertsch. 1993. Electrophoretic mobility and particle size of clays using laser doppler velocimetry-photon correlation spectroscopy. Soil Science Society of America Journal 57:1641-1643.

Dosskey, M.G. and P.M. Bertsch. 1994. Forest sources and pathways of organic matter transport to a blackwater stream: A hydrologic approach. Biogeochemistry 24:1-19.

Herbert, B.E. and P.M. Bertsch. Characterization of dissolved and colloidal organic matter in soil solution: A critical review. Soil Science Society of America special publication. (in press).

Hunter, D.B. and P.M. Bertsch. 1994. In situ measurements of tetraphenylboron degradation kinetics on clay mineral surfaces by IR. Environmental Science and Technology 28(4):686-691.

Kaplan, D.I., P.M. Bertsch, D.C. Adriano, and K. Orlandini. Actinide association with groundwater colloids in a Coastal Plain aquifer. Radiochimica Acta (in press).

Kaplan, D.I., D.B. Hunter, P.M. Bertsch, S. Bajt, and D.C. Adriano. 1994. Application of synchrotron $\mathrm{X}$-ray fluorescence spectroscopy and energy dispersive X-ray analysis to identify contaminant metals on groundwater colloids. Environmental Science and Technology 28(6):1186-1189. 


\section{F.4. METAL TOXICOLOGY}

\section{Metal Toxicity}

M. C. Newman

This program began with a study of mercury release from the Effluent Treatment Facility (ETF) and has subsequently been revised to consider mercury and other metals in other SRS areas. At present, it includes a recently completed regional survey of mercury bioaccumulation in mosquitofish, metal bioaccumulation modeling in SRS-pertinent species, and metal effects on mosquitofish and other species. It will continue to consider other sites, species and contaminants as the needs of SRS managers change.

A regional survey of mercury bioaccumulation by mosquitofish did not support the hypothesis that mercury concentrations in on-site fish were higher than those from off site because of SRS-related releases. However, mercury concentrations in this species were significantly higher at sites influenced by the Savannah River. Optimal sampling methods were also developed and detailed in the associated report (see reference below).

Biochemical indicators of population-level response to toxicants continue to be developed. Kramer and Newman published an article exploring further the effect of the glucose phosphate isomerase (PGI-2) locus on effect to mercury-exposed mosquitofish. Long-term mesocosm studies continue with a recent sampling. Duplicate mesocosms with PAR Pond sediments have been added to the six existing mesocosms. Samples for stress protein analysis in fish from these mesocosms have been taken and will be analyzed by Dr. Brenda Sanders at California State University - Long Beach.

Bioaccumulation studies using radiotracers have been initiated in catfish. Cadmium, cesium, mercury, rubidium and zinc elimination kinetics will be assessed. Methods for measuring methylmercury kinetics in catfish and largemouth bass are also in development. An innovative model of bioaccumulation was recently developed in this program and will be published in 1995.

\section{Recent Publications: Metal Toxicology}

Benson, W., J. Alberts, H. Allen, C. Hunt, and M.C. Newman. 1994. Bioavailability of metals in aquatic environments. p. 63-71. In Bioavailability: Physical. Chemical and Biological Interactions, edited by J.L. Hamelink, P.F. Landrum, H.L. Bergman, and W.H. Benson. Lewis Publishers, Inc. Proceedings of the Thirteenth Pellston Workshop, Pellston, MI.

Kramer, V.J. and M.C. Newman. 1994. Inhibition of glucose phosphate isomerase allozymes of the mosquitofish, Gambusia holbrooki, by mercury. Environmental Toxicology and Chemistry 13: 914.

Newman, M.C. 1994. Quantitative ecotoxicology of metals in aquatic systems. Proceedings of the U.S. EPA/Israel Ministry of Environment Workshop on Monitoring and Modeling Water Quality. Haifa, Israel (in press).

Newman, M.C. Chapter 5. Environmental research on mercury by the Savannah River Ecology Laboratory. In Assessment of Mercury in the Savannah River Site Environment. Westinghouse Savannah River Company, Aiken, SC (in press). 
Newman, M.C. Quantitative Methods in Aquatic Ecotoxicology. Lewis Publishers, Inc., Chelsea, MI. (in press).

Newman, M.C. and C. Jagoe. 1994. Inorganic ligands and the bioavailability of metals in aquatic environments. p. 39-61. In Bioavailability: Physical, Chemical and Biological Iinteractions, edited by J.L. Hamelink, P.F. Landrum, H.L. Bergman, and W.H. Benson. Lewis Publishers, Inc. Proceedings of the Thirteenth Pellston Workshop, Pellston, MI.

Newman, M.C. and R.M. Jagoe. Bioaccumulation models with time lags: Dynamics and stability criteria. Ecological Modelling (in press).

Newman, M.C., M.M. Keklak, and S.M. Doggett. 1994. Quantifying animal size effects on toxicity: A general approach. Aquatic Toxicology 28: 1-13.

Newman, M.C. and A. Messier. 1994. Mercury bioaccumulation in mosquitofish (Gambusia holbrooki) sampled on and around the Savannah River Site. Savannah River Ecology Laboratory, Aiken, SC, SREL-48.

Newman, M.C., M. Mulvey, A. Beeby, R.W. Hurst, and L. Richmond. Snail (Helix aspersa) exposure history and possible adaptation to lead as reflected in shell composition. Archives of Environmental Contamimation and Toxicology (in press). 


\section{G. BIODIVERSITY ON THE SRS}

Results from the biodiversity program will provide information for the development of strategies and options for land managers at SRS and similar ecosystems to enhance biological diversity while using forest resources. The program addresses short- and long-term effects of management options on the diversity of plant and animal life. This cooperative research, unique in combining the talents and resources of federal agencies, industry, and academia, will allow the Department of Energy to manage the resources of the SRS in an environmentally sound manner, recognizing current and anticipated regulatory requirements. 


\section{G.1. RESOURCE MANAGEMENT}

\section{Distribution of Large Stands in the Region of the Savannah River Site}

J. E. Pinder, III

The deforestation of the southeastern United States was an important contributing factor leading to extinctions of native species such as the Ivory-Billed Woodpecker and Carolina Parakeet which required large, continuous areas of forest. Many of the currently endangered or threatened species, such as the Red-Cockaded Woodpecker, also require large expanses of forest, especially forests of older, larger trees. For this reason, SREL has been using Landsat multispectral satellite images (MSS) to identify and map stands of older-growth pine and hardwood forests in a $100 \times 100 \mathrm{~km}$ region centered on the SRS. The SRS comprises about $8 \%$ of this area, and is the only large, public land holding in the region.

The MSS images allow mapping hardwood and pine stands to a resolution of 1 ha (i.e, $100 \times 100 \mathrm{~m}$ ), and comparisons of MSS images from 1974, 1979, 1984, 1988 and 1991 allow the identification of forest stands that have been in continuous existence since 1974. Although some of these stands may have been created as late as 1964, this procedure does separate those stands that are potentially older-growth forests from those which have been manipulated within the last 20 years. Moreover, it identifies those stands that may be potentially managed to produce older-growth forests.

Forests comprise approximately 50\% of the region around the SRS, but much of this forest is either 1 ) in relatively small patches of less than 10 ha, or 2) is relatively young forest. This pattern occurs due to the commercial harvesting of pines, and the subdivision of the region into mostly small private land holdings. Pines cover approximately $20 \%$ of the region but only $7 \%$ of the region is older-growth pine stands larger than 10 ha. One-half of these stands are located on the SRS. Much of the region's existing pine forest was established or replanted after 1974, and one-half the region's 1974 pine forest had been cut by 1991 .

Hardwood forests cover $30 \%$ of the region with much of this forest occurring on the floodplain of the Savannah River. Other extensive stands of hardwoods occur on the floodplain of the Edisto River and on the floodplains of smaller creeks such as Upper Three Runs and Brier Creek. Because there is less cutting and management of hardwood forests, large stands of older-growth hardwood trees are more common. Approximately $20 \%$ of the region is covered by older-growth hardwood stands larger than 10 ha.

Very large, that is greater than 100 ha, stands of older-growth forests are rare. Only $0.5 \%$ of the region is in older-growth pine stands larger than 100 ha. There are approximately 30 of these pine stands, and most of them occur on the SRS. The largest older-growth pine stand in the region comprises about 500 ha and is located in the northern half of the SRS. Approximately $4 \%$ of the region is covered by older-growth hardwood forests of 100 ha or more in extent. In contrast to pines, relatively little of the old, large hardwood stands are located on the SRS. Most of these stands are on the floodplain of the Savannah River. south of the SRS. 
These percentages of very large stands of older-growth pines and hardwoods should be considered overestimates. The older-growth pine stands on the SRS are composed mostly of trees planted since 1952 and are still relatively young forests for species such as the Red-Cockaded Woodpecker. Much of the older-growth hardwoods are also relatively young as there was extensive cutting of the floodplain hardwood forests during the late 1800 s and early 1900s. As recently as the 1940s there was extensive cutting of hardwood forests on lands that would become the SRS due to the activities of the Lee Banana Case Company located near old Ellenton. Thus, relatively little of the region supports large expanses of forests that are likely to be true old-growth forests. The absence of these stands is clearly expressed in the extinct, endangered, threatened or rare status of the animal species which inhabit them.

\section{Effects of Land Management Practices on Forest Biodiversity D. W. Imm and K. W. McLeod}

During FY94 our biodiversity project concentrated on four research areas; 1) sandhills post-burn recovery, 2) timber compartment manipulation, 3) diversity of setaside slopes, and 4) Sarracenia minor habitat and community dynamics. Each project illustrates how land management practices alter forest diversity.

\section{Post-burn Recovery in Sandhills Vegetation}

This project concerns the effects of fire on community structure, composition and biodiversity. The research focuses on two sandhill set-aside areas located near PAR Pond and B-Area. Past research focused on post-burn recoveries in a summer burnt area (August 1980) and winter burnt area (January 1981). These studies have revealed that: 1) diversity has declined since the seventh year of post-burn recovery, 2) longleaf pine reestablishment has declined, 3) the importance of scrub oaks has dramatically increased over the past 5 years, and 4) the numbers of annuals and fire-adapted herbs and grasses have declined markedly since the seventh year of post-burn recovery. The increase in the number of scrub oaks is particularly evident for the smaller size classes of oaks.

This research will give further insight on how sandhill vegetation should be managed to favor fire tolerant endemics and species-rich spatial mosaics. This information, coupled with data collected over the past 16 years from permanently positioned plots, should reveal the spatial and temporal dynamics of the sandhill community. The information then could be used as a management tool to increase plant species and habitat diversity.

\section{Effects of Management at the Timber Compartment Level}

This research is intended to study the effects of differing management strategies on biodiversity at the timber compartment level. Our approach has been to select two 
adjacent timber compartments (TC\#32 and TC\#33) that have slightly different management goals and then to compare patterns of species diversity within each relative to management and microsite conditions.

Sampling efforts during FY94 focused on revisiting permanent plots in both timber compartments to evaluate compositional changes that occurred due to recent management activities. During FY94 efforts were made to compare and contrast vegetation differences within eleven vegetation types and to determine how they equate to soil and topographic conditions. We determined that species diversity and richness do not differ greatly between managed pine and set-aside hardwood areas at a small scale such as individual plots $\left(400 \mathrm{~m}^{2}\right)$. However, because hardwood systems have a wider variety of canopy species of different ages there is much greater spatial diversity than the managed pine systems. Further, the "representitiveness" of species, or large-scale heterogeneity, within planted pine systems is much less than that associated with hardwood slopes and bottomlands. However, under extreme moisture conditions endemic species are present in actively managed and passively managed stands. Collectively, passively managed stands have greater numbers of species and greater numbers of endemics except those occurring on excessively drained soils.

Future direction of the timber compartment project will focus on manipulations (replanting, thinning, timber removal, burning, etc.) of individual timber stands in both timber compartments. This will allow for a fine-grained approach to determine the effects of currently used management techniques on species richness and diversity. During FY95 GPS locations will be determined for each of the permanently marked plot positions within both of the timber compartments. This will allow for the coupling of GIS and plot information.

\section{Diversity of Set-Aside Slopes}

In terms of diversity, Set-Aside hardwood slopes are important because they function as refugia from disturbances (fire, timber harvest, etc.) for intolerant species. Additionally, they provide habitat for animals. We sampled 5 additional sloped areas to result in a collective representation of 21 hardwood-dominated slopes within the Upper Three Runs Creek Set-Aside corridor.

We determined that many associations exist and most are strongly affixed to particular topographic or environmental attributes. The most prevalent canopy associations are; 1) scrub oak-pine, 2) post oak-southern red oak-scrub oak-hickory, 3) white oak-mockernut hickory-southern red oak, 4) northern red oak-pignut hickory-mixed hardwood, 5) beech-holly-laurel oak, 6) black walnut-mulberry-oak-hickory, 7) sweetgum-water oak-loblolly pine, and 8) red bay-holly-mixed hardwoods. For each canopy association a ground cover association also exists. During FY94, greater emphasis was placed on defining shrub, seedling, and herbaceous cover relative to those species in the canopy.

Because of the loose association of species with each of these groups an alternative approach has also been taken to determine the relationship between individual 
species and their environment. This involves the determination of optimum environmental conditions for each species that then can be incorporated into predictive models and later tested either experimentally or through comparison with additional data from other areas. From the standpoint of management for sustainable diversity this information can be used to strengthen the relationship between natural environmental gradients and associated species turnover rates (beta diversity).

This study has revealed that Set-Aside buffers between hardwood slopes and pinemanaged areas influence composition. Those slopes near pine managed areas had greater seedling densities and basal areas of loblolly pine, sweetgum, and water oak near the ridge when compared to those slopes away from pine managed areas. This pattern is likely due to greater seed rain from adjacent areas for these species (loblolly pine, sweetgum, water oak) over the past several years.

\section{Sarracenia minor Habitat and Community Dynamics}

During FY94, new initiatives were developed at Craig's Pond to consider vegetation patterns in a natural pine system and to assess the population dynamics of the pticher plants, Sarracenia minor, relative to resource availability and spatial patterning within the pine system. Preliminary results suggest that biomass and productivity are strongly influenced by depth to water table and light availability. Furthermore, these attributes of the pitcher plant population and resource availability are strongly correlated with spatial positioning of shrubs and trees.

Three additional areas within the pine corridor surrounding Craigs Pond were used to map and sample vegetation. The additional areas were positioned relative to moisture and hydrologic conditions. These areas and that used for pitcher plant monitoring represent a vegetational catena along a sub-xeric to hydric moisture gradient.

The long-term purposes of this study are to identify and quantify vegetational gradients in natural pine systems from the standpoint of habitat suitability for rare and endemic plants. An additional goal is to determine if fire along this gradient has stimulatory effects on pitcher plants and other endemics under the existing habitat conditions. Further, the impact of fire on these systems may differ relative to inherent moisture and hydrologic conditions.

\section{Recent Publications: Resource Management}

Bertram, T. E. and A. E. Cook. 1993. Satellite imagery and GPS-aided ecology. GPS World 4:48-53.

Cook, A. E. and J. E. Pinder III. Relative accuracy of rectifications using coordinates determined from maps and global positioning systems. Photogrammetric Engineering and Remote Sensing (in press).

Golley, G. B., J. E. Pinder, III, P. J. Smallidge, and N. J. Lambert. 1994. Limited invasion and reproduction of loblolly pines in a large South Carolina old field. Oikos 69:21-27. 
Imm, D. W., K. W. McLeod, S. W. Workman, and P. Camill. Eleven years of post-fire change in summer and winter burned sandhill ridges of the upper Coastal Plain. Bulletin of the Torrey Botanical Club (in press).

Imm, D. W. and J. S. Clark. Geographic and climatic influences on tree species abundance within the Eastern Deciduous Forest. Vegetatio (in press).

White, J. D. , G. C. Kroh, and J. E. Pinder, III. Mapping forest species at Lassen Volcanic National Park, California, using Landsat Thematic Mapper Data and a Geographical Information System. Photogrammetric Engineering and Remote Sensing (in press). 


\section{G.2. FAUNAL DIVERSITY}

\section{Herpetofaunal Biodiversity Studies on the SRS}

J. W. Gibbons

The Savannah River Site provides an ideal environment for the study of herpetofaunal biodiversity due to its wide variety of terrestrial and aquatic habitats, large tracts of protected land, and different management regimes throughout the landscape. In addition, the history of the SRS along with the availability of human and material resources have resulted in long-term intensive studies that have generated a large database on the resident herpetofauna. Our long-term goal is to use this database and future data to develop and implement field techniques to enhance or restore herpetofaunal biological diversity within a managed landscape. The specific objectives of our herpetofaunal biodiversity research program are:

(1) To quantify variations in herpetofaunal population size not due to management regimes (i.e., daily, seasonal, or yearly variation, wetland hydroperiod, and environmental variation due to habitat differences).

(2) To determine the microdistribution of each of the herpetofaunal species occuring on the SRS and how it is affected by the distribution of soil types and vegetation communities.

In order to meet these objectives, we have set out coverboard arrays at different types of terrestrial habitats and at the land-water interface of several temporary and semipermanent Carolina bays. These boards are maintained throughout the year and some have been censused since the late 1980s. The early data have already been compiled in a book chapter, but future publications and student research projects are anticipated.

A project to meet the second objective began this fall and involves using GIS and all existing data on SRS herp captures to map out the distribution of herpetofaunal species on the SRS. Once these microdistributions have been determined, it will be possible to compare them to results of soil and vegetation surveys previously conducted by other groups.

These data will suggest mechanisms leading to enhanced or reduced amphibian and reptile biodiversity within managed habitats. Comparative and experimental data will give us the unique opportunity to elucidate steps to mitigate the effects of various standard management practices on herpetofaunal biodiversity, and will provide the means for managers to fulfill congressional ecological mandates subject to economic contraints on land use. 
Stream Fish Community Biodiversity, Species Interactions and Mutualisms, and Population Diversity

G.K. Meffe and D.E. Fletcher

\section{$\underline{\text { Stream Fish Community Biodiversity }}$}

Emphasis in this program remains focused on the effects of beaver dams on stream fishes. Beaver dam construction, maintenance, and eventual decline and destruction are important components of local and stream-wide composition of fish communities. Quarterly sampling of beaver dams and associated streams continued through 1994. Also, incorporation of GIS continues to progress. This information will permit identification of former and current beaver dams, including a historical perspective of dam dynamics. Intense field sampling of fish communities, and measurement of habitat changes due to dams will continue on a quarterly basis. This summer we also began an intensive sampling program on aquatic vegetation diversity in beaver ponds and streams.

Species Interactions and Mutualisms

Initial observations of the nest association of dusky shiners (Notropis cummingsae) and redbreast sunfish (Lepomis auritus) on the SRS were published in Copeia in early 1993. Experiments were conducted in replicate cattle tanks to address the following questions: 1) Is this nest association a parasitic relationship? 2) Is the association facultative or obligatory for dusky shiners? 3) Do dusky shiners preferentially select sunfish larvae while feeding in nests? Results indicate that this is a parasitic relationship; dusky shiners do select host offspring when feeding in the nests; and dusky shiners are an obligate nest associate. A new and improved cattle tank facility was constructed at the Aquatic Ecology Laboratory in spring 1993 and expanded in spring 1994. It will allow more sophisticated experimentation with these and other fishes.

Experiments conducted in 1993 further supported the nest association between redbreast sunfish and dusky shiners as being parasitic. In two successive years, redbreast sunfish that were spawned alone in tanks produced three times as many offspring as those spawned with symbiont shiners present. Additional experimentation has also indicated that at least in captivity, dusky shiners will spawn in nests of spotted sunfish, but the nest associaton may not affect the spotted sunfish as detrimentally as the redbreast. Experiments and field nest surveys in progress (summer 1994) will provide more information on these relationships.

\section{Population Differences}

Quarterly collections continue to be made of mosquitofish (Gambusia holbrooki) across ten sites on the SRS to compare life history patterns in a diversity of habitats. Reproduction, body shape, and lipid storage dynamics are being compared across the ten sites, and analysis of several year's data will commence in fall 1994. Thirteen sites 
(including many of the ten regularly sampled sites) were used in a test of a theory on overwinter lipid storage, and a manuscript was submitted to Oecologia in September 1994. A second paper on comparative lipid use in mosquitofish of Pond $C$ and Risher Pond was published in Copeia in 1993, and a third paper, on a laboratory experiment to test details of lipid use in reproduction, was published in the Canadian Journal of Fisheries and Aquatic Sciences in 1993. We also conducted studies on patterns of cannibalism in mosquitofish at several SRS sites, and that paper was published in Copeia in 1993.

\section{Changes in Fish Assemblages in a Reactor Cooling Reservoir in Relation to Reactor Operation}

J. D. Congdon and R. D. Nagle

Pond $C$ is part of the PAR Pond reservoir system on the SRS. It has received chronic and acute impact from heated effluent from operation of P-Reactor. In addition, Pond $\mathrm{C}$ has had water levels reduced because of the drawdown of the PAR Pond system. We have monitored the fish assemblage in Pond $\mathrm{C}$ from approximately two years before reactor shutdown to present. Fish samples were collected using an electroshocking boat during four distinct periods, 1) reactor operation, 2) reactor shutdown, 3) six months after draw down, and 4) one year or more after draw down. A total of seventeen species of fish were caught, and data were collected on 4,851 fish during the four collection periods. 2,038 fish were individually marked with permanent tags. The two species of numerically dominant fish (excluding mosquitofish) during all four periods were bass, which accounted for $27-61 \%$ of the assemblage, and bluegill, which accounted for 22 $41 \%$. The number of species increased from five dominant species during reactor operation to about 12 dominant species during the period following reactor operation. The number of dominant species in each sample has remained stable at about 12 during the remaining sampling periods. Some of the new dominant species entering the pond during the past three sampling periods were yellow perch, black crappie, redbreast sunfish, warmouth and lake chub sucker, which are more typical of fish assemblages in normothermic ponds. We will continue systematic collections on Pond $\mathrm{C}$ to determine if or when the fish community of Pond $\mathrm{C}$ comes to a relatively stable equilibrium in the number of species and numerical dominance.

\section{Recent Publications: Faunal Diversity}

Meffe, G. K. and C. R. Carrol. 1994. Principles of Conservation Biology. Sinauer Associates, Sunderland, MA.

Meffe, G. K. and F. F. Snelson, Jr. 1993. Annual lipid cycle in eastern mosquitofish (Gambusia holbrooki: Poeciliidae) from South Carolina. Copeia 3:596-604.

Meffe, G. K. and F. F. Snelson, Jr. 1993. Lipid dynamics during reproduction in two livebearing fishes, Gambusia holbrooki and Poecilia latipinna. Canadian Journal of Fisheries and Aquatic Sciences 50:2185-2191.

Nesbit, D. H. and G. K. Meffe. 1993. Cannibalism frequencies in wild populations of eastern mosquitofish (Gambusia holbrooki: Poeciliidae) in South Carolina. Copeia 3:867-870. 


\section{G.3. DOE SET-ASIDES}

\section{DOE Research Set-Aside Areas}

C. E. Davis

The purpose of the Set-Aside program is to establish lands on the Savannah River Site (SRS) that represent unique and natural habitats of the region, to offer protection to rare, threatened, and endangered biota that inhabit these areas, and to provide sites on the SRS that are conducive to long-term ecological research. In addition, these undisturbed natural areas serve as control sites for evaluating impacts from SRS site operations and intensive forest management activities. Through the Set-Aside program, the protection and preservation of these areas not only will aid in sustaining a high degree of biological diversity on the site, but also will fulfill the Department of Energy's (DOE) need to maintain the SRS as a National Environmental Research Park (NERP).

The Savannah River Ecology Laboratory (SREL) developed a computer based Geographical Information System (GIS) data layer describing the Set-Aside boundaries, and a final working version (Version 3 ) has been distributed to the SRS coordinating land users. This GIS layer is used on site to ensure that Set-Aside boundary lines are available for consideration by SRS groups making land management decisions. It was determined from the coverage that area for the present 30 Set-Asides totals approximately 14,230 acres ( $5758 \mathrm{ha})$, and that boundary length totals 284 miles $(176 \mathrm{~km})$ of posted line.

Procedures for periodic inspections of Set-Aside boundary postings were written and implemented. All SREL Site Use Permits were evaluated to determine if the permitted research activity was conducted in a Set-Aside and to assess closure plan implementation to determine if a potential ecolitter site existed for that Set-Aside.

SREL's Set-Aside staff participates as an ID team member in the SRFS's timber compartment prescription review process for developing natural resource management plans. This coordination with the SRFS is successful in verifying Set-Aside and timber stand boundary line coincidence with GIS coverages, in updating sensitive plant population surveys conducted in Set-Aside areas, and in addressing potential conflicts with forestry activities adjacent to Set-Aside areas prior to initiating Site Use permit coordination. Pre-planning activities for the SRFS's prescribed burning programs continued.

In FY 1993, SREL supported a U.S. Environmental Protection Agency (EPA) wetland Advanced Identification (ADID) Project by identifying the highest quality bay wetlands on the SRS. All Carolina bay Set-Asides were recommended for inclusion into the project. The goal of the Carolina Bay ADID Project in South Carolina is to enhance the protection of these wetland ecosystems by identifying the most important examples which remain in the state.

A NERP document describing the flora, fauna, and biophysical parameters that comprise and support each Set-Aside area is nearly ready for submission to DOE. Reference files are continuously updated for each Set-Aside area to include photos, maps, and all publications and research efforts associated with each Set-Aside.

The Set-Aside program solicited proposals for small research projects to be conducted in Set-Aside areas to include floral, faunal, and geochemical-based projects. 
Two projects were funded this year and a third received funding pending Set-Aside Task Group approval. Projects funded included water snake activity patterns and habitat use, landscape influences on fish species diversity of Carolina bay Set-Asides, and experimental burning for pitcher plant population enhancement. SREL continued numerous on-going studies in Set-Asides. Groups other than SREL also utilized the SetAside.

Future accomplishments for the Set-Aside program will focus on finalizing the NERP document on Set-Aside areas, developing a management plan for each Set-Aside area, utilizing the Set-Asides for educational outreach purposes, expanding archaeological investigations of Carolina bays and evaluating other SRS GIS coverages that include Set-Aside boundaries. Another priority will be establishing permanent plots for gathering baseline data for those Set-Asides where survey data are lacking. The sensitive plant survey being conducted by the SRFS will continue to be updated and incorporated into the Set-Aside GIS coverage. Continued research within Set-Aside areas will provide valuable baseline information that will aid DOE in the operation, restoration, and remediation of SRS site facilities.

Recent Publications: DOE Set-Asides [publications that used Set-Asides]

Belk, M. C. and C. Lydeard. 1994. Effect of Gambusia holbrooki on a similar-sized, syntopic Poecliid, Heterandria formosa: Competitor or predator? Copeia 2:296-302.

Brooks, M. J., B. E. Taylor, J. A. Grant, and E. Gaiser. 1993. Upland wetlands investigation of Pleistocene-Holocene environmental change on the SRS. In Annual Review of Cultural Resource Investigations by the SRARP - Fiscal Year 1993. p. 27-37.

Browder, T. A., R. D. Brooks, and D. C. Crass. 1993. Memories of home: Dunbarton and Meyers Mill remembered. Occasional papers of the Savannah River Archaeological Research Program Community History Project, S.C. Institute of Archaeology and Anthropology. University of South Carolina. Columbia, SC. 183 pp.

Burke, V. J., J. W. Gibbons, and J. L. Greene. 1993. Prolonged nesting forays by common mud turtles Kinosternon subrubrum. American Midland Naturalist 131:190-195.

Debiase, A. E. and B. E. Taylor. 1993. New occurrences of Eurytemora affinis and Epischura fluviatilis, freshwater calanoid copepod species of the Family Temoridae, in South Carolina. American Midland Naturalist 130:386-392.

Davis, G. M. and M. Mulvey. 1993. Species Status of Mill Creek Elliptio - SRO-NERP-22. University of Georgia Savannah River Ecology Laboratory. Publication of the Savannah River National Environmental Research Park Program. Aiken, SC.

Golley, F. B., J. E. Pinder III., P. J. Smallidge and N. J. Lambert. 1994. Limited invasion and reproduction of loblolly pines in a large South Carolina old field. Oikos 69:21-27.

Hartman, G. D. and J. D. Krenz. 1993. Estimating population density of moles Scalopus aquaticus using assessment lines. Acta Theriologica 38:305-314.

Hepp, G. R. and R. A. Kennamer. 1993. Effects of age and experience on reproductive performance of wood ducks. Ecology 74:2027-2036.

Jones, R. H., R. R. Sharitz, P. M. Dixon, D. S. Segal and R. L Schneider. Woody plant regeneration in four floodplain forests. Ecological Monographs (in press). 
Kramer, V. J. and M. C. Newman. 1994. Inhibition of glucosephosphate isomerase allozymes of the mosquitofish, Gambusia holbrooki, by mercury. Environmental Toxicology and Chemistry 13:914.

Krenz, J. D. and D. E. Scott. 1994. Terrestrial courtship affects mating locations in Ambystoma opacum. Herpetologica 50(1):46-50.

Leff, L. G., J V. McArthur, and L. J. Shimkets. 1993. Spatial and temporal variability of antibiotic resistance in freshwater bacterial assemblages. FEMS Microbiology Ecology 13:135-144.

Leff, L.G.and J.V. McArthur. 1994 Effect of macroinvertebrates on detachment of bacteria from biofilms in stream microcosms. Journal of the North American Benthological Society 13:74-79.

Lydeard, C. and M. C. Belk. 1993. Management of indigenous fish species impacted by introduced mosquitofish: An experimental approach. The Southwestern Naturalist 38(4):370-373.

McArthur, J. V., J. M. Aho, R. B. Rader, and G. L. Mills. 1994. Interspecific leaf interactions during decomposition in aquatic floodplain ecosystems. Journal of the North American Benthological Society 13(1):57-67.

Nesbit, D. H. and G. K. Meffe. 1993. Cannabalism frequencies in wild populations of the eastern mosquitofish (Gambusia holbrooki: Poeciliidae) in South Carolina. Copeia 1993:867-870.

Meffe, G. K., and F. F. Snelson, Jr., 1993. Annual lipid cycle in eastern mosquitofish (Gambusia holbrooki: Poeciliidae) from South Carolina. Copeia 1993:596-604.

Pechmann, J. H. K. and H. M. Wilbur. 1994. Putting declining amphibian populations in perspective: Natural fluctuations and human impacts. Herpetologica 50(1):65-84.

Plummer, M. V., and J. D. Congdon. 1994. Radiotelemetric study of activity and movements of racers (Coluber constrictor) associated with a Carolina bay in South Carolina. Copeia 1994:20-26.

Scott, D.E. The effect of larval density on adult demographic traits in Ambystoma opacum. Ecology (in press).

Semlitsch, R. D., and S. C. Walls. 1993. Competition in two species of larval salamenders: A test of geographic variation in competitive ability. Copeia 1993:587-595.

Sheldon, A. L. and G. K. Meffe. 1993. Multivariate analysis of feeding relationships of fishes in blackwater streams. Environmental Biology of Fishes 37:161-171.

U. S. Environmental Protection Agency. 1994. High Risk Geographic Areas Targeted for Wetland Advanced Identification. EPA 904-R- 94-005. 


\section{H. ENVIRONMENTAL TOXICOLOGY}

The objective of this program is to continue and expand investigations of toxic effects (including genotoxicity) on organisms exposed to contaminated or polluted habitats on the SRS. Studies on genotoxic effects will include development of new biochemical, histological and ultrastructural indices to detect damage to cell nuclei, and refinement of flow cytometric methods previously employed. Sublethal stresses from environmental contaminants will be assessed in selected natural populations by physiological and histological techniques. Additionally, "sentinel species" surveys will be conducted, in which animals are placed in contaminated or polluted sites and monitored using the above indices for selected periods of time. Laboratory exposures to simulate environmental conditions also will be performed. These studies will provide important information on: (1) potential sources of sublethal stresses and genetic damage, including identification of sites where contamination is producing measurable effects, (2) re-evaluation of levels of exposure to radiation or other pollutants considered non-hazardous, and (3) effectiveness of mitigation efforts. 


\section{Genotoxicology Studies}

R. K. Chesser, C. H. Jagoe, M. H. Smith, and I. L. Brisbin, Jr.

The purposes of this research are to develop and test biomarkers of chronic exposure of organisms to low levels of radionuclides, toxic metals and other pollutants. One class of biomarkers involves the detection of environmental agents that produces genetic damage. For example, exposure to genotoxic pollutants can cause alterations in cellular DNA content. One method to detect abnormal cellular DNA content, flow cytometry, may be used to rapidly screen large numbers of organisms. We completed a series of experiments to develop quality control and quality assurance procedures, and to assess various sample handling, cell separation and analysis protocols on fish blood DNA profiles. These studies have resulted in two manuscripts to date. In 1992 and 1993, more than 2,600 largemouth bass were sampled from Pond B, Pond C, PAR Pond, L-Lake and the Steel Creek Swamp on the SRS, and from off-site locations in Georgia and South Carolina. SRS sampling sites contained low levels of ${ }^{137} \mathrm{Cs}$ and other radionuclides, and heavy metals such as mercury. Some offsite locations were also polluted with heavy metals or PCBs, while others had no known contaminants. Blood samples were obtained and most fish were released unharmed, but some were sacrificed for future analysis of contaminant body burdens. In 1994, additional fish were collected from a subset of these sites, and overall fish health was measured using a health assessment index (HAI) involving detailed examination of hematology, body fat, condition factor, and the gross appearance of liver, kidney, gill and other organs. The frequency of fish with abnormallyvariable blood cell DNA content was greater in locations with known histories of pollution, both on and off the SRS. However, most fish had normal cellular DNA content, even in polluted locations. Overall fish health as measured by the HAI method did not differ among SRS and offsite locations. HAI scores were also not related to DNA content abnormalities as detected by flow cytometry. This research produced a Ph.D. dissertation in Pharmacology and Toxicology in 1994, and several manuscripts detailing the results are in preparation.

Breakage of DNA strands in response to contaminant exposure can be directly measured using an alkaline unwinding assay. We are now using this technique to measure DNA damage in fish and molluscs exposed to radionuclides and toxic metals. In a study recently submitted for publication, DNA strand breakage was measured in bass from several SRS reservoirs and an offsite location. Tissue levels of ${ }^{137} \mathrm{Cs}$ and mercury were also determined. DNA strand breakage was not strongly correlated with ${ }^{137} \mathrm{Cs}$ content of muscle, but was related to mercury concentration. Methods to examine blood cell nuclei for abnormalities by light and scanning electron microscopy have been developed and will be applied to detect nuclear abnormalities associated with genetic damage. Several species of fish were surveyed to provide a baseline for comparison with contaminant-exposed fish, and two manuscripts describing normal nuclear structure and interspecies variation are in preparation.

To assist in interpretation of field results, and to test and validate new methods of measuring genetic damage, we have begun laboratory experiments involving exposure to genotoxic agents under controlled conditions. An X-ray system allowing controlled radiation exposure was purchased in 1994 . We are presently experimenting with two new 
techniques for measuring genetic damage. The single-cell gel electrophoresis assay allows the measurement of DNA damage in individual cells. The p53 gene activation assay measures a protein associated with a tumor-suppression gene that has been implicated in carcinogenesis in humans. Both of these techniques will be employed to detect genotoxic effects in wild organisms exposed to environmental contaminants. A transplantation experiment was also begun. Bullhead catfish from an uncontaminated location will soon be placed in a large enclosure in Pond B on the SRS. Uptake of contaminants $\left({ }^{137} \mathrm{Cs}\right.$ and mercury) by these fish will be measured over time, and samples will be collected to detect potential genetic damage associated with contaminant uptake.

To further explore potential relationships between exposure to radionuclides and other environmental contaminants and DNA damage, research in contaminated locations near the Chernobyl nuclear power plant in Ukraine is continuing. Samples have been collected, including fish, molluscs and small mammals within the 10-kilometer and 30kilometer exclusion zones. In 1992, samples were taken in lightly-contaminated areas along the edge of the 30-kilometer zone. In 1993 and 1994, more contaminated locations closer to the reactor were sampled. Flow cytometric analyses of the 1992 and 1993 fish samples have been completed, and a number of abnormalities in DNA content potentially associated with contaminant exposure have been detected. Contaminants including radionuclides, mercury and lead have also been measured in these samples, and several manuscripts describing the results are in preparation. In the past year, we also purchased a thermoluminescent dosimetry reader, and have begun monitoring external gamma radiation exposure in these environments. Measurement of DNA strand breakage by alkaline unwinding in fish and mollusc samples is also underway. In 1994, systematic sampling of terrestrial mammals near the reactor was begun. Genetic damage in these samples will be assessed using cytogenetic and molecular techniques. These research endeavors are very promising and have received recognition from scientists and government agencies worldwide. We were invited to submit a chapter to a forthcoming Russian volume about the ecological effects of the Chernobyl accident.

\section{Recent Publications: Environmental Toxicology}

Dallas, C. E., C. H. Jagoe, S. K. Fisher, K. A. Holloman, R. K. Chesser, M. H. Smith and M. Lomakin. Evaluation of genotoxicology in wild organisms due to the Chernobyl nuclear disaster. In Animal World and Ecosystems in Conditions of Radioactive Pollution. Nauka Science Publishers. Russian Academy of Sciences, Moscow (in press).

Fisher, S. K., C. E. Dallas, C. H. Jagoe, M. H. Smith, I. L. Brisbin, Jr. and R. K. Chesser. Sources of error associated with sample collection and preparation of nucleated blood cells for flow cytometric analysis. Cell Biology and Toxicology (in press).

Fisher, S. K., C. H. Jagoe, C. E. Dallas, R. K. Chesser, M. H. Smith and I. L. Brisbin, Jr. 1994. Assessment of genetic damage as a biomarker in the remediation of contaminated or polluted sites. p. 629-634. In Proceedings of the ER93 Environmental Remediation Conference. U. S. Department of Energy. Washington, DC.

Fisher, S. K., J. T. Lingenfelser, C. H. Jagoe and C. E. Dallas. Evaluation of the effects of cryopreservation of isolated erythrocytes and leukocytes of largemouth bass (Micropterus salmoides) by flow cytometry. Journal of Fish Biology (in press). 


\section{ENVIRONMENTAL OUTREACH AND EDUCATION}

This program is designed to educate the public about ecological research and environmental issues, with emphasis on SREL and the SRS. This is done through communication of information to the popular press, including newspapers, magazines, and various electronic media, and through oral presentations to schools, civic groups, garden clubs and other organizations interested in environmental issues. Efforts also include participation in exhibits that serve the goals of environmental education and tours of SREL and the SRS that emphasize ecological research programs and environmental initiatives. Various student research participation and teacher training programs at SREL are also being organized and operated as part of this effort. 


\section{ENVIRONMENTAL OUTREACH AND EDUCATION}

\section{J. W. Gibbons}

This program is designed to educate the public about ecological research and environmental issues, with emphasis on SREL and the SRS. This is done through communication of information to the popular press, including newspapers, magazines, and various electronic media, and through oral presentations to schools, civic groups, garden clubs, and other organizations interested in environmental issues. Efforts also include participation in exhibits that serve the goals of environmental education and through tours of SREL and field sites on the SRS that emphasize ecological research programs and environmental initiatives. Various student research participation and teacher training programs at SREL also are being organized and operated as part of this effort.

The Division of Environmental Outreach and Education was created at SREL during the 1991 fiscal year. The program is designed to enhance SREL's overall mission of acquiring and communicating environmental knowledge and addresses DOE's current focus on environmental issues.

The Environmental Outreach and Education Division presents talks to local schools, civic groups, and other organizations averaging about four presentations per week and approximately three tours every three weeks. The Division has been responsible for managing the laboratory's education program and developing an enhanced public awareness of environmental issues on the SRS and ongoing ecological research.

During the past year, SREL scheduled 223 lectures, 47 tours and 16 exhibits. One exhibit, the Palmetto Sportsmen's Classic in Columbia, S.C., was attended by an estimated 75,000 people.

Most of the lectures and presentations have been made at schools, children's camps, civic organizations, and garden clubs. Topics for the presentations have included animal ecology and outdoor safety, plants and wetlands, the environment, conservation, and careers in ecology and research.

The public relations program has included the mailing of news releases to a regular list of about 200 media affiliates and officials of DOE and the University of Georgia. The program has also promoted various research projects through coverage in local and national media, and worked to enhance the laboratory's internal communications. Included among these have been coverage of SREL research by CNN, Associated Press, BioScience, Environment Magazine, National Wildlife Magazine, and National Public Radio. This program also has been responsible for planning and organizing special events, including tours for dignitaries and several reptile and amphibian identification workshops for the general public. Ongoing projects include two internal laboratory newsletters, one published on a monthly basis, the other weekly, and an increased number of video projects. A 27-minute six-projector, automated slide presentation about SREL research was completed this year. This presentation is a regular part of SREL tours. Another innovative educational product completed this year was a 
set of three environmental jigsaw puzzles. These puzzles have received high praise from educators across the nation.

The division has also assumed management responsibilities for the laboratory's education program. In SREL's education program this fiscal year, nearly 68 high school students, undergraduate and graduate students, and pre-college teachers conducted research at SREL. Many of the participants were from Georgia and South Carolina, but students also were represented from 18 other states.

The undergraduate students, whose education and training have been supported by DOE, were funded in part by a grant of approximately $\$ 50,000$ from the National Science Foundation (NSF). During this summer, 11 of the 22 undergraduate students were supported by NSF funding.

Also this summer, SREL participated in a program for pre-college teachers sponsored by Associated Western Universities. Five Teacher Research Associates (TRAC) program participants conducted research at the laboratory. At SREL, the program participants attended seminars, lesson-planning sessions, and weekly discussions on research articles. Participants in this summer program, directed for the laboratory by senior ecologist Dr. Whit Gibbons, also could receive five hours of graduate credit from Mercer University for their participation.

Finally, a visiting faculty program was initiated to support visiting college and university faculty members who conduct research in collaboration with a SREL colleague. Participants during the summer of 1994 are listed in section IIIA. 


\section{J. PAR POND DRAWDOWN STUDIES}

The PAR Pond Reservoir System is a cooling reservoir located on the SRS, where the water level has been maintained at about 210 feet above sea level for more than 30 years. During the summer of 1991, the water level in PAR Pond was drawn down approximately 19 feet. This action, ordered by the Department of Energy, was undertaken to reduce the impact of a potential dam failure while assessing the condition of the dam structure and determining if repairs were necessary. Because of this drawdown, potential radiological and ecological impacts had to be determined. Savannah River Ecology Laboratory began monitoring programs on wildlife and fish at PAR Pond in July 1991. 


\section{J.1. ECOLOGICAL EFFECTS OF THE PAR POND DRAWDOWN: WILDLIFE STUDIES}

\section{Wildlife Studies}

I. L. Brisbin Jr.

Wildlife research studies, initiated in July of 1991 to document the effects of the PAR Pond drawdown on native fauna, are continuing into the 1994 study season. Night eye-shine censuses of alligators on the PAR Pond reservoir continue to be performed on a monthly basis with about 75 to 100 alligators being counted on each survey. Seven alligators equipped with radio transmitters are being located monthly. Of these 7 alligators, 6 were radio-collared in previous years and one received a transmitter for the first time. Efforts are being made to replace transmitters on other alligators that were radio-collared in previous years and either lost their transmitters or have dead transmitter batteries. Within the period of August 1, 1993 to July 31, 1994, seventeen alligators were captured using a snare-set trap baited with fish. Fourteen of these 17 alligators were recaptures and 2 were killed by larger alligators.

Studies that evaluate the effects that sex, size and season have on the movements of these alligators were started in the spring of 1993 and are continuing. Archiving of alligator data is ongoing.

In 1992 and 1993, we determined radiocesium burdens, by gamma spectroscopy, of mourning doves using the PAR Pond exposed lakebed as foraging habitat. We compared these radiocesium burdens to those from doves collected at offsite public hunting control areas $11 \mathrm{~km}$ and $21 \mathrm{~km}$ from the contaminated lakebed. Whole-body, wet-mass, radiocesium burdens of offsite hunter-harvested birds averaged $0.94 \pm 0.99$ (SE) $\mathrm{Bq} / \mathrm{kg}(\mathrm{n}=48,62.5 \%$ were below detection limits) and $2.24 \pm 0.76(\mathrm{SE}) \mathrm{Bq} / \mathrm{kg}$ ( $\mathrm{n}=60,53.3 \%$ were below detection limits) and did not differ between years. Radiocesium burdens of birds collected at PAR Pond, however, averaged $195.61 \pm 28.63$ (SE) Bq/kg in $1992(\mathrm{n}=19)$ and declined significantly in $1993(105.89 \pm 6.80(\mathrm{SE}) \mathrm{Bq} / \mathrm{kg}$; $\mathrm{n}=45$ ). We detected no differences between sexes of doves. Radiocesium burdens in PAR Pond doves likely reflect an increased bioavailability of the radionuclide following drawdown; the decline over the two years may reflect decreasing bioavailability as the radionuclide moves downward in the soil profile. Though radionuclide levels in these doves pose little risk for human consumption, this study demonstrates that mourning doves may serve as vectors of contaminants from the PAR Pond CERCLA site, and that environmental disturbance may affect contaminant bioavailability.

Sightings of bald eagles and ospreys continue to be recorded for PAR Pond. The reservoir again has been frequented by juveniles as well as adult eagles. Annual systematic census cruises to count wading birds and other avifauna were continued at all major SRS reservoirs through 1994.

Studies using radio-telemetry continue to document the movement and behavior of terrestrial box turtles inhabiting wooded habitat bordering the CERCLA unit. These studies have shown that, unlike turtles in control habitats off the SRS, the turtles in this area have no specific locations to which they continue to return each year at the time of winter dormancy. Although none of the telemetered turtles actually entered the CERCLA 
site this year, they continue to move over much broader expanses of habitat than those in the control area.

\section{Recent Publications: PAR Pond Drawdown: Wildlife Studies}

Bildstein, K. L., D. E. Gawlik, D. P. Ferral, I L. Brisbin, Jr. and G. R. Wein. 1994. Wading bird use of established and newly created reactor cooling reservoirs at the Savannah River Site, near Aiken, South Carolina, USA. Hydrobiologia 279/280:71-82.

Brisbin, I. L., Jr. 1993. Birds as monitors of radionuclide contamination. In Birds as Monitors of Environmental Change, edited by R. W. Furness and J. J. D. Greenwood. p. 144-178. Chapman and Hall, London.

Brisbin, I. L., Jr. 1994. Chapter 17. Applications of a modified Richards sigmoid model to assess the uptake and effects of environmental contaminants upon birds. p. 161-170. In Proceedings of the Ninth Pellston Workshop: Wildlife Ecology and Population Modeling, edited by R. J. Kendall and T. E. Lacher, Jr. Lewis Publishers. Boca Raton, FL. 


\section{J.2. ECOLOGICAL EFFECTS OF THE PAR POND DRAWDOWN: FISH AND METAL STUDIES}

Fish Community Structure, Reproductive Changes in Mosquitofish, and Lipid Composition and Cycling in Mosquitofish

G. K. Meffe and S. C. Weeks

\section{Community Sampling}

Community samples in Sanctuary Cove of Pond $\mathrm{C}$ were continued this year. Numbers of individuals and species have declined with the re-establishment of the feeder stream from the formerly lentic habitat. Species composition has begun to stabilize.

\section{Mosquitofish Life History Patterns}

Mosquitofish have become more abundant in Pond $\mathrm{C}$, but are still rare and difficult to collect in PAR Pond. We hope to obtain small samples from both sites this year and are analyzing them.

\section{Lipid Analysis}

We completed quantitative genetic analyses of life history developmental patterns, including lipid storage, and submitted a manuscript in August 1994 to Evolution. Other related aspects of that study remain to be analyzed.

Changes in Fish Assemblages and Reproductive and Whole Body Lipid Cycles of Bluegills

J. D. Congdon, R. D. Nagle, and R. U. Fischer

During the periods when we have had access to PAR Pond, we have been monitoring the effects of prolonged drawdown on species composition, survival and population sizes of fish. In addition, we have sampled Pond $C$ and PAR Pond fish to determine the reproductive state of females and their body condition by determining whole body lipids. We have collected and marked 1,536 fish (18 species) from PAR Pond and 2,268 from Pond C (17 species). A total of 314 recaptures have been caught in both ponds, 232 in Pond $\mathrm{C}$ and 82 in PAR Pond. The two most dominant species in both ponds are bass and bluegill, which comprise about $50 \%$ and $20 \%$ of the total fish assemblage, respectively in both reservoirs. During the prolonged drawdown period, the number of species in each sample has remained stable at 9 and 12 for PAR Pond and Pond $\mathrm{C}$, respectively. However, during the long reactor down period, we have observed a variety of species in both sites disappearing with new species taking their place, indicating a community not at equilibrium. We will continue to systematically sample 
both PAR Pond and Pond $\mathrm{C}$ to make an accurate assessment of population size and survival.

We also have collected bluegill samples over the past eight months for determination of whole body lipid and reproductive state of fish from both sites. We plan to continue systematic sampling of bluegill for the next four months to determine the annual lipid and reproductive cycles of bluegills from both ponds.

\section{Trace Metal Content of Fish and Mercury Accumulation in PAR Pond Bass}

C. H. Jagoe

Significant changes in biotic and abiotic conditions occurred when PAR Pond was partially drained. These changes included increased erosion and sediment resuspension, altered thermal regimes, and changes in fish habitat and water chemistry. The PAR Pond system contains mercury and other potentially toxic trace metals, as well as radionuclides. The purpose of this research is to determine if the altered conditions in PAR Pond have affected mercury levels in fish and other biota. This study also will yield information about trace metal cycling in reservoir systems, including effects of environmental perturbations such as altered water level or chemistry.

Samples of largemouth bass have been collected quarterly since December 1991, except for the period during 1992 when access to PAR Pond was restricted. The most recent sampling was done in late May and early June 1994. Water samples were collected at semi-monthly intervals. Samples of forage fish, plants, alligators and benthic invertebrates were also collected. Digestion and analysis protocols, including rigorous QA/QC provisions, have been developed and tested, and are being routinely used on biological samples. Mercury analyses have been completed on bass samples collected through spring 1994, and analyses of other plant materials, benthic invertebrates and forage fish species have also been completed to date.

From fall 1991 through spring 1994, mercury content of largemouth bass in PAR Pond ranged from $0.05-1.90 \mathrm{mg} / \mathrm{kg}$ wet weight, based on analysis of about 500 samples. Mercury content in bass did not differ among locations within PAR Pond, but was strongly related to fish size. Catchable-size bass generally contained more mercury than the $0.5 \mathrm{mg} / \mathrm{kg}$ FDA consumption advisory limit.

Initially, bass condition factor increased as small forage fishes were displaced from cover in littoral macrophyte beds by the drawdown. Bass gorged on these fish, but as the forage populations declined from the excessive predation and lack of refugia, bass condition factor has declined, and is presently lower than before the drawdown. Analysis of forage species showed that they varied in mercury content, with the highest levels (mean $0.13 \mathrm{mg} / \mathrm{kg}$ wet mass) in brook silversides (Labidesthes sicculus). By about 6 months after the drawdown, there was a transient increase in bass muscle mercury levels, probably associated with the increased prey consumption. However, over the drawdown period to present, there has been no significant overall trend in mercury content of bass.

Little mercury was present in four genera of aquatic macrophytes sampled (mean $<0.03 \mathrm{mg} / \mathrm{kg}$ wet mass), but up to $0.6 \mathrm{mg}$ mercury $/ \mathrm{kg}$ wet mass was found in benthic molluscs. Alligators, a top level predator in this system, were found to contain substantial amounts of mercury (mean approximately $7 \mathrm{mg} / \mathrm{kg}$ wet weight in liver). 
Mercury burden was also directly proportional to the size of the alligator. Results of the studies on fish and other biota were presented at the International Meeting on Mercury as a Global Pollutant in July 1994.

The utility of measuring the activity of the enzyme $\mathrm{Na}^{+} / \mathrm{K}^{+}$ATPase as a biomarker of effects of mercury exposure was evaluated using gill samples from bass. Previous literature reports suggested that mercury is a potent inhibitor of this enzyme in fish. Contrary to expectations, higher mercury levels in tissues were associated with higher activities of this enzyme in bass from the SRS. We plan to examine more samples to clarify this effect.

Current plans call for the refilling of PAR Pond as early as late winter 1995. Studies from other reservoirs strongly suggest that refilling will cause increased mercury levels in bass and other organisms. Refilling will flood the presently-exposed sediments where succession has produced communities of terrestrial plants. When these are killed by the increased water level, anaerobic decomposition of these plants will produce conditions favorable for the microbial methylation of mercury. This methylation will make inorganic mercury presently immobilized in the sediments biologically available, resulting in enhanced accumulation. To test this scenario, we plan uptake experiments involving caged fish before and after the refill. Monitoring of bass and other organisms will also continue on a regular basis during and after the refill period.

\section{Recent Publication: PAR Pond Drawdown: Fish and Metal Studies}

Fischer, R. U. 1994. Morphological, physiological, and life history changes of bluegill sunfish in response to thermal stress. Ph.D. Dissertation, the University of South Carolina.

Newman, M. C. and C. H. Jagoe. 1994. Ligands and the bioavailability of metals in aquatic environments. p. 39-61. In Bioavailability: Physical, Chemical and Biological Interactions, edited by J.L. Hamelink, P.F. Landrum, H.L. Bergman, and W.H. Benson. Lewis Publishers, Inc. Proceedings of the Thirteenth Pellston Workshop, Pellston, MI. 


\section{K. THEORETICAL ECOLOGY}

None of the environmental and ecological data collected on the SRS are precisely accurate. Chance variability affects every measurement. Some of the variation stems from measurement error; some stems from variability among individuals, among sites, and over time. The goal of statistical analysis is twofold: to extract correct conclusions from imprecise data and to quantify our belief in the truth of those conclusions. This research program component will develop and evaluate statistical methods for the analysis of environmental and ecological data. 


\section{Theoretical Ecology}

P. M. Dixon

This program includes two research components. The first studies the theoretical properties of sigmoidal curves, used as statistical models for growth curves and toxicant accumulation curves. The second develops and evaluates statistical methods to estimate trends in ecological communities.

During FY94, we purchased necessary software, assembled relevant data sets, and started to compare different models. This work will continue in FY95. 


\section{DOE-SR NATIONAL ENVIRONMENTAL RESEARCH PARK}

The Savannah River Site was the first of six National Environmental Research Parks created and maintained on DOE reservations throughout the United States. The SRS research park was dedicated in 1972 with the purposes of promoting environmental research, conservation and protection of natural resources. 


\section{DOE-SR NATIONAL ENVIRONMENTAL RESEARCH PARK}

\section{National Environmental Research Park Program \\ R. K. Chesser}

The goals of the National Environmental Research Park Program (NERP) have been to synthesize information relevant to the biological resources and vital processes on the SRS, to maintain and make available relevant data collected on the SRS, and to provide services to SREL scientists. The NERP initiatives have undergone annual changes as directed from DOE-OHER, and the final disposition of the NERP program has now fallen to local DOE offices because it is no longer supported by DOE-OHER. One of the prime initiatives in the last year has been to finalize the chapters for the first Annual SREL Symposium on Environmental Sciences for Spatial and Temporal Aspects of Population Processes. All chapters have been completed and edited, and the final versions submitted to the publisher (Univ. Chicago Press) for printing in late 1995. Another report, Species Status of Mill Creek Elliptio, was published during FY94. This report details the distribution and densities of these rare freshwater mussels on the SRS. The NERP program also played a role in supporting the continuing efforts of SREL to place all data generated on the SRS into a computer retrievable archive system. This is an ongoing endeavor because new data are constantly being generated. A computerized system for retrieval and entry of data has been developed and maintained.

\section{Recent Publications: DOE-SR National Environmental Research Park}

Davis, G. M. and M. Mulvey. 1993. Species Status of Mill Creek Elliptio. SRO-NERP-22. University of Georgia Savannah River Ecology Laboratory. Publication of the Savannah River National Environmental Research Program. Aiken, SC.

Rhodes, O. E., Jr., R. K. Chesser, and M. H. Smith (eds.). Spatial and Temporal Aspects of Population Processes. SREL Symposia on Environmental Sciences. University of Chicago Press. Chicago, IL (in press). 


\section{WILDLIFE STUDIES}

Organisms live in a constantly changing environment that challenges their ability to survive and reproduce. The perturbations that organisms face come from a variety of sources including direct or indirect effects of human activity. Responses to change occur at various levels from the gene through to the organism and at the population level and beyond. The goal of these studies is to examine the response of organisms to environmental perturbations at all levels at which the responses occur. Emphasis is placed on understanding responses to the natural range of variation so that responses to anthropogenic perturbations can be analyzed in an appropriate context. 


\section{WILDLIFE STUDIES}

\section{H. Smith}

We are in the process of extending our capability to conduct experiments with the mosquitofish. To fully take advantage of this situation we have constructed a tank farm with over 100 mesocosms and are constructing another one to expand our ability to conduct more realistic and powerful experiments. We are also working with a device in which to raise virgin fish for founders for the experimental populations. The first experiments to be conducted in this facility have been completed and used to answer basic questions concerning the population dynamics in the mesocosms. This allowed us to establish a base line with which to evaluate the effects of a variety of other variables including anthropogenic stressors. The first of a series of experiments analyzing demographic and genetic responses of mosquitofish to salt stress has been completed. Experiments have been completed and several papers published examining the response of salamanders and frogs (Ambystoma opacum and Hyla sp.) to biotic and abiotic variation in light of previous results of long term studies on amphibian population dynamics. In all of the on-going experiments, the genetic dynamics of the experimental populations and the genetic-environmental interactions will be determined. The general purpose of these experiments will be to test hypotheses concerning explanations for the variations in population numbers that are often observed in natural settings. In order to fully understand genetic responses and especially the genotype-environment interaction, we have expanded our genetic analyses to include quantitative genetic experiments investigating morphological and life history characters. To this end, experiments have been started to determine the heritability and norms-of-reaction of size-shape characteristics of mosquitofish living on the SRS.

We continue to extend the protocols for the genetic analyses of polymorphic loci in, and the number of, indicator species inhabiting a diversity of habitats on the SRS. Work on hybridization and systematics of mosquitofish in the region has been completed, and it is clear that the Savannah River drainage is an area of hybridization for two species of mosquitofish from this region. Implications of this finding for other species that occur on the SRS need to be taken into account when interpreting data collected on their biology. Four doctoral dissertations are in progress dealing with the genetics of mosquitofish and marbled salamanders living under a variety of environmental conditions on the SRS. The resulting patterns in these vertebrates will be useful for evaluating possible genetic effects of stress on the SRS.

\section{Recent Publications: Wildlife Studies}

Belk, M. C. and C. Lydeard. 1994. Effect of Gambusia holbrooki on a similar-sized, syntopic Poeciliid, Heterandria formosa: competitor or predator? Copeia 1994:296-302.

Hartman, G. D. Age determination, age structure, and sex ratios in the mole, Scalopus aquaticus. Journal of Mammalogy (in press). 
Hartman, G. D. and J. D. Krenz. 1993. Estimating population density of moles, Scalopus aquaticus, using assessment lines. Acta Theriologica 38:305-314.

Krenz, J. D. and D. E. Scott. 1994. Terrestrial courtship affects male mating strategy in Ambystoma opacum. Herpetologica 50:46-50.

Lydeard, C. and M. C. Belk. 1993. Management of indigenous fish species impacted by introduced mosquitofish: an experimental approach. Southwestern Naturalist 38:370-373.

McAlpine, S. 1993. Genetic heterozygosity and reproductive success in the green treefrog, Hyla cinerea. Heredity 70:553-558.

Novak, J. M., O. E. Rhodes Jr., M. H. Smith and R. K. Chesser. 1993. Morphological asymmetry in mammals: genetics and homeostasis reconsidered. Acta Theriologica 38, Suppl. 2: 7-18.

Scribner, K. T. 1993. Hybrid zone dynamics are influenced by genotype specific variation in life history traits: experimental evidence from hybridizing Gambusia species. Evolution 47:632-646.

Scribner, K. T. and J. C. Avise. 1993. Molecular evidence for phylogeographic population structure and introgressive hybridization in mosquitofish. Molecular Ecology 2:139-149.

Scribner, K. T. and J. C. Avise. 1994. "Population cage" experiments with a vertebrate: the temporal demography and cytonuclear genetics of hybridization in experimental populations of Gambusia fishes. Evolution 48:155-171. 


\section{AWARDS AND HONORS}

\section{Honors}

Dr. Ronald Chesser, head of SREL's Wildlife Ecology and Toxicology Division, was promoted from associate to senior faculty member.

Dr. I. Lehr Brisbin, Jr. was elected to the rank of Fellow in the American Association for the Advancement of Science. He was honored for over two decades of research in vertebrate ecology and ecotoxicology aimed at understanding the fate and effects of radioactive contaminants in the environment.

Drs. Sue Clark and Tom Hinton were among ten American scientists chosen to participate in a National Academy of Sciences Program on Nuclear Accidents and Radioactive Contamination. The program, held during the summers of 1993 and 1994, involved collaboration with ten other young investigators from Belarus and Ukraine.

Dr. Whit Gibbons was elected board chairman of the South Carolina Heritage Trust Program.

Dr. Sue Clark was named Young Alumna of the Year at her alma mater, Lander University.

Tonya Youngblood, a research technician and student at the University of South Carolina-Aiken, received a $\$ 1,000$ scholarship from the South Carolina Chapter of the Aquatic Plant Management Society.

Dr. Justin Congdon was inducted into the Victor Valley College alumni Hall of Fame in Victorville, California for his outstanding accomplishments in the field of ecology.

Dr. Michael Newman was one of eight U.S. scientists selected to participate in a workshop on "Monitoring and Modelling Water Quality" jointly sponsored by the U.S. Environmental Protection Agency and the Ministry of the Environment of Israel.

Dr. Beverly Collins was elected secretary for the Association of Southeastern Biologists.

Dr. Rebecca Sharitz was elected Vice Chair, Vegetation Section, Ecological Society of America. 


\begin{abstract}
Awards
Clark McCreedy, a SREL graduate student from Purdue University, received the "Best Student Paper" award from the Indiana Chapters of the Wildlife Society and the American Fisheries Society for his paper on "Characterization of Catfish Immune Cells by Cell Flow Cytometry".

Graduate student Adrienne Edwards received the Outstanding M.S. Thesis Award presented by the University of Georgia Chapter of Sigma Xi, The Scientific Research Society.

Graduate student Vincent Burke was awarded the Student Research Award in aquatic biology at the Annual Meeting of the Association of Southeastern Biologists. The award was presented for his manuscript and presentation entitled, "Evaluating wetland conservation policies with GIS models of habitat use by aquatic turtles."

Research technician Kim Ritchie won three awards at the South Carolina Academy of Science at USC-Aiken: (1) the Sigma Xi Award for Outstanding Undergraduate Research in Biology, (2) the American Association for the Advancement of Science Award for Best Overall Female Presentation, and (3) the Byrne Award for Best. Undergraduate Paper.

David Scott won the Best Student/Technician Paper award from UGA's Institute of Ecology. His paper, "The effect of larval density on adult demographic traits in Ambystoma opacum," summarized his research on marbled salamanders from the past eight years.
\end{abstract}

The winners of SREL's Student/Technician Poster Day 1994 were: first place - Doug Leeper for his poster "Benthos abundance, biomass and production in a Carolina bay wetland;" second place - Tracy Lynch for her poster "Preliminary male-male courtship observations in the marbled salamander Ambystoma opacum;" and a tie for third place Victor Parrish for his poster "Restoration methods of inundated bottomlands" and Kathryn Gubista - for her poster "Peromyscus population decline: Measures of genetic diversity." 


\section{EDUCATION PROGRAM PARTICIPANTS (summers of 1993 and 1994)}

\section{A. PARTICIPANTS IN THE EDUCATION PROGRAM}

\begin{tabular}{lll} 
Short-term Graduate & Participation Program \\
\hline Michele Basham & M.S. & Texas Christian University \\
Vicky Batson & M.S. & Texas A\&M University \\
Loretta Battaglia & Ph.D. & University of Georgia \\
Christopher Beck & Ph.D. & University of Georgia \\
Matthew Brady & M.S. & Auburn University \\
Kurt Buhlmann & Ph.D. & University of Georgia \\
Vincent Burke & Ph.D. & University of Georgia \\
Anne Chazal & M.S. & Auburn University \\
Robert Cheney & Ph.D. & University of Georgia \\
Krista Clements & M.S. & Univeristy of Georgia \\
Michael Draney & Ph.D. & University of Georgia \\
Adrienne Edwards & M.S. & University of Georgia \\
Aissa Feldmann & M.S. & University of Georgia \\
Nicholas Haddad & Ph.D. & University of Georgia \\
Randall Hudson & M.S. & Texas A\&M University \\
Scott Johns & M.S. & Clemson University \\
Mark Komoroski & Ph.D. & University of Georgia \\
John Lee & M.S. & University of Georgia \\
Susan Miller & M.S. & University of Georgia \\
Kim Orrell & M.S. & Virginia Tech \\
Patrick Pierce & M.S. & University of Georgia \\
*Christoper Salice & M.S. & Drexel University \\
Pamela Schultz & M.S. & University of Georgia \\
Michael Schwartz & M.S. & University of Georgia \\
Julian Singer & M.S. & University of Georgia \\
Craig Stockwell & Ph..D. & University of Nevada \\
William Straw & Ph.D. & University of Georgia \\
Susan Turner & Ph.D. & University of Georgia \\
Julie Weis & Ph.D. & University of Georgia \\
Dana Winkelman & Ph.D. & University of Georgia \\
Rebecca Yeomans & Ph.D. & University of Georgia \\
& & \\
\hline & &
\end{tabular}

*These students received a scholarship from the Environmental Restoration and Waste Management Scholarship Program through Oak Ridge Associated Universities

\section{Visiting Faculty on Sabbatical}

\begin{tabular}{ll}
\hline Stephen Dobson & Auburn University \\
Thomas Jenssen & Virginia Tech \\
Joseph Rule & Old Dominion University
\end{tabular}

\section{Long-term Graduate Participation Program}

Evelyn Gaiser
Kathryn Gubista
Christopher Harrison
Frank Hensley
Christopher Hudson
Karen Kandl
John Krenz
Clark McCreedy
Vicki Medland
Mark Mills
Thomas Risch
Joel Snodgrass

Ph.D. University of Georgia

Ph.D. University of Georgia

Ph.D. Texas A\&M University

Ph.D. University of Florida

Ph.D. University of Georgia

Ph.D. University of Georgia

Ph.D. University of Georgia

Ph.D. Purdue University

Ph.D. University of Georgia

Ph.D. University of Georgia

Ph.D. Auburn University

Ph.D. University of Georgia
Undergraduate Research Participation Program

Jennifer Andes Kalamazoo College

Anupa Batra

Sharla Benjamin

Bradley University

Russell Bodie

Michelle Boone

Sandy Brundage

Reide Corbett

Jeffery Demuth

Silvia Diaz-Conde

Joan Gariboldi

Leila Hadj-Chikh

Evonnie Hart

Scott Henry

Jennifer Hopper

Frederick James

Russell Jeffers

Charles Kean

Michael Lloyd

Angela Long

Carrie McCracken

Charles Mitchell

Camille McNeely

Anne Osborn

Tracey Parker

Christine Phelps

Jennifer Piascik

Russell Prescott

Duke University

University of South Carolina

Furman University

Auburn University

Florida State University

Harding University

University of Nevada

College of St. Francis

Wilkes University

Westmont College

University of Georgia

University of Georgia

Paine College

Erskine College

Berry College

Westminster College

Memphis State University

Drew University

Emory University

University of Texas

University of South Florida

Warren Wilson College

Eastern Michigan University

University of Georgia

University of South Carolina

Christine Rabideau St. Michael's College
Lisa Rania
Ryan Reardon
Kerrey Roberto
Michelle Safter
Geoffrey Siemering
Kelley Smith
Carrie Thomas
Tywaun Tillman
Tracey Tuberville
Travis Tuchak
Billy Webb
Chris Wheat
Kathryn Wilson
Gina Yanochko

St. Mary's College
Rhodes College
Hendrix College
Colby College
Pomona College
Southeastern Louisiana University
University of Wisconsin
Furman University
Furman University
Virginia Tech
Clemson University
Emory University
Drexel University
Virginia Tech

$\underline{\underline{\text { TRAC }}}$

George Anderson
Carole Bennett
Daniel Funsch
John Hoon
Edward Moore
Julie Mootz
Shadidur Rahman
Connie Singleton
Donna South
Martin Wolfson
Julie Walker

Vero Beach Junior High

Jesuit High School

The Alleluia Community School

Hawkins Middle School

Lake Clifton-Eastern Sr.High School

St. Mary's School

Eskridge High School

Robert Smalls Middle School

Bay High School

Lincolin Park Academy

Southport High School 


\section{YOUNG SCHOLARS}

Mandy Dickerson

Dan Fulcher

Eddie Moore

Melissa Newman
Hephzibah High School

Hephzibah High School

Barnwell High School

Strom Thurmond High School

\section{High School Research Participation}

Rebecca Byrd Davidson Fine Arts Magnet School

Tracey Parker South Aiken High School

\section{B. Recent Master's and Doctoral Degree Recipients}

Holloman, K. A. 1993. Spatial and temporal patterns of radiocesium contamination in mosquitofish (Gambusia holbrooki) inhabiting a nuclear reactor cooling reservoir. M.S. Thesis, The University of Georgia. Advisor: I. L. Brisbin.

Batson, V. L. 1994. Surface water transport and distribution of uranium in contaminated sediments near a nuclear weapons processing facility. M.S. Thesis, Texas A \& M University. Advisor: P. M. Bertsch.

Fischer, R. U. 1994. Morphological, physiological, and life history changes of bluegill sunfish in response to thermal stress. Ph.D. Dissertation, The University of South Carolina. Advisor: J. D. Congdon.

Fisher, S. K. 1994. Flow cytometric assessment of DNA damage in largemouth bass as a biomarker to evaluate genotoxicity related to environmental contaminant exposure. Ph.D. Dissertation, The University of Georgia. Advisor: C. E. Dallas.

Hudson, R. J. 1994. Weathered diesel oil as a sorptive phase for hydrophobic organic compounds in aquifer material. M. S. Thesis, Texas A \& M University. Advisor: G. L. Mills.

May, A. M. Basham. 1994. Comparing the utility of Landsat TM and SPOT XS data for mapping shrub and meadow communities in Lassen Volcanic National Park. M.S. Thesis, Texas Christian University. Advisor: J. E. Pinder. 


\section{PUBLICATIONS AND PRESENTATION}

\section{A. Journal Articles and Book Chapters Published}

SREL

Reprint No.

1743 Burke, V.J. 1993. Lepidochelys kempii (Kemp's Ridley sea turtle) and Caretta caretta (Loggerhead sea turtle) diet. Herpetological Review 24:31-32.

1744 Scribner, K.T. and J.C. Avise. 1993. Cytonuclear genetic architecture in mosquitofish populations and the possible roles of introgressive hybridization. Molecular Ecology 2:139-149.

1745 Coulter, M.C. and A.L. Bryan Jr. 1993. The foraging ecology of wood storks (Mycteria americana) in east-central Georgia. I. Characteristics of foraging sites. Colonial Waterbirds 16:59-70.

1746 Sharitz, R.R., M.R. Vaitkus, and A.E. Cook. 1992. Hurricane damage to an old-growth floodplain forest in the southeast. Seventh Biennial Southern Silvicultural Research Conference, Mobile, AL 1992:203-210.

1747 Leberg, P.L. 1990. Influence of genetic variability on population growth: Implications for conservation. Journal of Fish Biology 37:193-195.

1748 Semlitsch, R.D. and S.C. Walls. 1993. Competition in two species of larval salamanders: A test of geographic variation in competitive ability. Copeia 1993:587-595.

1749 Meffe, G.K. and F.F. Snelson Jr. 1993. Annual lipid cycle in eastern mosquitofish (Gambusia holbrooki: Poeciliidae) from South Carolina. Copeia 1993:596-604.

1750 Nesbit, D.H. and G.K. Meffe. 1993. Cannibalism frequencies in wild populations of the eastern mosquitofish (Gambusia holbrooki: Poeciliidae) in South Carolina. Copeia 1993:867-870.

1751 Boone, J.L., J. Laerm, and M.H. Smith. 1993. Taxonomic status of Peromyscus gossypinus anastasae (Anastasia Island cotton mouse). Journal of Mammalogy 74:363-375.

1752 Leberg, P.L. and M.H. Smith. 1993. Influence of density on growth of white-tailed deer. Journal of Mammalogy 74:723-731.

1753 Anderson, M.A., P.M. Bertsch, and L.W. Zelazny. 1993. Chapter 7. Multicomponent transport through soil subjected to coal pile runoff under steady saturated flow. In Trace Elements in Coal and Coal Combustion Residues, edited by R.F. Keefer and K.S. Sajwan. p. 137-164. Lewis Publishers. Boca Raton, FL. 
1754 Boone, J.L. and J. Laerm. 1993. Cotton mice, Peromyscus gossypinus LeConte (Rodentia: Cricetidae), from the Great Dismal Swamp and surrounding areas. Brimleyana 18:125-129.

1755 Martin, H.W., D.A. Graetz, S.J. Locascio, and D.R. Hensel. 1993. Nitrification inhibitor influences on potato. Agronomy Journal 85:651-655.

1756 Hinton, T.G., P. Kopp, S. Ibrahim, I. Bubryak, A. Syomov, and L. Tobler. 1993. Contaminated soil on Chernobyl vegetation. p. 407-421. In Proceedings of the Twenty-Sixth Midyear Topical Meeting of the Health Physics Society: Environmental Health Physics, edited by R.L. Kathren, D.H. Denham, and K. Salmon. Columbia Chapter, Health Physics Society. Coeur d'Alene, ID.

1757 Whicker, F.W., D.J. Niquette, and T.G. Hinton. 1993. To remediate or not: A case history. p. 473-485. In Proceedings of the Twenty-Sixth Midyear Topical Meeting of the Health Physics Society: Environmental Health Physics, edited by R.L. Kathren, D.H. Denham, and K. Salmon. Columbia Chapter, Health Physics Society. Coeur d'Alene, ID.

1758 Hinton, T.G. 1993. Variation among model predictions within an IAEA validation exercise. p. 138-143. In Proceedings of the Topical Meeting on Environmental Transport and Dosimetry, American Nuclear Society, Inc. Charleston, SC.

1759 Wolff, J.O. 1993. What is the role of adults in mammalian juvenile dispersal? Oikos 68:173-176.

1760 Congdon, J.D. and R.C. van Loben Sels. 1993. Relationships of reproductive traits and body size with attainment of sexual maturity and age in Blanding's turtles (Emydoidea blandingii). Journal of Evolutionary Biology 6:547-557.

1761 Cooper, W.E. 1993. Tree selection by the broad-headed skink, Eumeces laticeps: Size, holes, and cover. Amphibia-Reptila 14:285-294.

1762 Dosskey, M.G. and D.C. Adriano. 1993. Trace element toxicity in VA mycorrhizal cucumber grown on weathered coal fly ash. Soil Biology and Biochemistry 25:1547-1552.

1763 Sandhu, S.S., G.L. Mills, and K.S. Sajwan. 1993. Chapter 8. Leachability of Ni, $\mathrm{Cd}, \mathrm{Cr}$, and As from coal ash impoundments of different ages on the Savannah River Site. In Trace Elements in Coal and Coal Combustion Residues, edited by R.F. Keefer and K.S. Sajwan. p. 165-182. Lewis Publishers, Inc. Boca Raton, FL.

1764 Menon, M.P., K.S. Sajwan, G.S. Ghuman, J. James, and K. Chandra. 1993. Chapter 12. Elements in coal and coal ash residues and their potential for agricultural crops. In Trace Elements in Coal and Coal Combustion Residues, edited by R.F. Keefer and K.S. Sajwan. p. 259-287. Lewis Publishers, Inc. Boca Raton, FL. 
1765 Hepp, G.R. and R.A. Kennamer. 1993. Effects of age and experience on reproductive performance of wood ducks. Ecology 74:2027-2036.

1766 Rhodes, O.E., Jr. and L.M. Smith. 1993. Relationships between genetic variation and carcass components in wintering American wigeons. Auk 110:354-360.

1767 McCreedy, C.D. and H.P. Weeks Jr. 1992. Sodium provision and wild cottontail rabbits: Morphological change in adrenal glands. Journal of Wildlife Management 56:669-676.

1768 Taylor, B.E., A.E. DeBiase, and D.L. Mahoney. 1993. Development of the zooplankton assemblage in a new cooling reservoir. Archiv fuer Hydrobiologie 128:129-148.

1769 Collins, B. and G.R. Wein. 1993. Competition between native and immigrant Polygonum congeners. Canadian Journal of Botany 71:939-945.

1770 Kennamer, R.A., C.D. McCreedy, and I.L. Brisbin Jr. 1993. Patterns of radiocesium contamination in eggs of free-ranging wood ducks. Journal of Wildlife Management 57:716-724.

1771 Brisbin, I.L., Jr. 1993. Conserving threatened components of the world's faunal biodiversity: the untapped resource of children's zoo programs. p. 276-282. In Regional Conference Proceedings of the American Association of Zoological Parks and Aquariums.

1772 Brisbin, I.L., Jr. and C. Bagshaw. 1993. Survival, weight changes, and shedding frequencies of captive scarlet snakes, Cemophora coccinea, maintained on an artificial liquid diet. Herpetological Review 24:27-29.

1773 Brisbin, I.L., Jr. 1994. Chapter 17. Applications of a modified Richards sigmoid model to assess the uptake and effects of environmental contaminants upon birds. p. 161-170. In Proceedings of the Ninth Pellston Workshop: Wildlife Ecology and Population Modeling, edited by R.J. Kendall and T.E. Lacher Jr. Lewis Publishers. Boca Raton, FL.

1774 Dixon, P.M. and K.A. Garrett. 1994. Chapter 41. Statistical issues for field experimenters. In Wildlife Ecology and Population Modeling: Integrated Studies of Agroecosystems, edited by R.J. Kendall and T.E. Lacher Jr. p. 439-450. Lewis Publishers. Boca Raton, FL.

1775 Taylor, B.E. and W. Gabriel. 1993. Optimal adult growth of Daphnia in a seasonal environment. Functional Ecology 7:513-521.

1776 Belk, M.C. 1993. Growth and mortality of juvenile sunfishes (Lepomis sp.) under heavy predation. Ecology of Freshwater Fish 2:91-98. 
1777 Chesser, R.K., K.B. Willis, and N.E. Mathews. 1993. Chapter 18. Impacts of toxicants on population dynamics and gene diversity in avian species. p. 171-188. In Proceedings of the Ninth Pellston Workshop: Wildlife Toxicology and Population Modeling. Integrated Studies of Agroecosystems, edited by R.J. Kendall and T.E. Lacher Jr. SETAC Special Publication Series. Lewis Publishers. Boca Raton, FL.

1778 Chesser, R.K., O.E. Rhodes Jr., D.W. Sugg, and A. Schnabel. 1993. Effective sizes for subdivided populations. Genetics 135:1221-1232.

1779 Rhodes, O.E., Jr., M.H. Smith, K.T. Scribner, and P.E. Johns. 1987. Factors affecting productivity of a white-tailed deer herd. p. 219-222. In Global Trends in Wildlife Management. Transactions of the 18th UIGB Congress, edited by B. Bobek, K. Perzanowski, and W. Regelin. Swiat Press. Krakow, Poland.

1780 Smith, M.H., K.T. Scribner, P.E. Johns, and O.E. Rhodes Jr. 1987. Genetics and antler development. p. 323-326. In Global Trends in Wildlife Management. Transactions of the 18th IUGB Congress, edited by B. Bobek, K. Perzanowski, and W. Regelin. Swiat Press. Krakow, Poland.

1781 Wolff, J.O. 1993. Why are female small mammals territorial? Oikos 68:364-370.

1782 Oliver, W.L.B. and I.L. Brisbin Jr. 1993. Introduced and feral pigs: problems, policy, and priorities. In Pigs, Peccaries and Hippos, edited by W.L.R. Oliver. p. 179-191. Status Survey and Conservation Action Plan of the IUCN World Conservation Union. Gland, Switzerland.

1783 Oliver, W.L.R., I.L. Brisbin Jr., and S. Takahashi. 1993. The Eurasian wild pig (Sus scrofa). In Pigs, Peccaries and Hippos, edited by W.L.R. Oliver. p. 112-121. Status Survey and Conservation Action Plan of the IUCN World Conservation Union. Gland, Switzerland.

1784 DeBiase, A.E. and B.E. Taylor. 1993. New occurrences of Eurytemora affinis and Epischura fluviatilis, freshwater calanoid copepod species of the family Temoridae, in South Carolina. The American Midland Naturalist 130:386-392.

1785 Frazer, N.B., J.L. Greene, and J.W. Gibbons. 1993. Temporal variation in growth rate and age at maturity of male painted turtles, Chrysemys picta. The American Midland Naturalist 130:314-324.

1786 Cooper, W.E. and L.J. Vitt. 1994. Tree and substrate selection in the semi-arboreal scincid lizard Eumeces laticeps. Herpetological Journal 4:20-23.

1787 Avery, H.W., J.R. Spotila, J.D. Congdon, R.U. Fischer, E.A. Standora, and S.B. Avery. 1993. Roles of diet protein and temperature in the growth and nutritional energetics of juvenile slider turtles, Trachemys scripta. Physiological Zoology 66:902-925. 
1788 Mayer, J.J. and I.L. Brisbin Jr. 1993. Distinguishing feral hogs from introduced wild boar and their hybrids: a review of past and present efforts. p. 28-49. In Feral Swine: A Compendium for Resource Managers, edited by C.W. Hanselka and J.F. Cadenhead. Texas Agricultural Extension Service. San Angelo, TX.

1789 Leberg, P.L., M.H. Smith, I.L. Brisbin Jr., and K.T. Scribner. 1987. Optimization strategies in a deer harvest program. p. 555-558. In Global Trends in Wildlife Management. Transactions of the IUGB Congress, edited by B. Bobek, K. Perzanowski, and W. Regelin. Swiat Press. Krakow, Poland.

1790 Hensley, F.R. 1993. Ontogenetic loss of phenotypic plasticity of age at metamorphosis in tadpoles. Ecology 74:2405-2412.

1791 Tinkle, D.W., A.E. Dunham, and J.D. Congdon. 1993. Life history and demographic variation in the lizard Sceloporus graciosus: A long-term study. Ecology 74:2413-2429.

1792 Wolff, J.O. 1993. Does the "chitty effect" occur in Peromyscus? Journal of Mammalogy 74:846-851.

1793 Scribner, K.T. and R.K. Chesser. 1993. Environmental and demographic correlates of spatial and seasonal genetic structure in the eastern cottontail (Sylvilagus floridanus). Journal of Mammalogy 74:1026-1044.

1794 Scribner, K.T. 1993. Conservation genetics of managed ungulate populations. Acta Theriologica 38, Suppl. 2:89-101.

1795 Chesser, R.K., D.W. Sugg, O.E. Rhodes Jr., J. Novak, and M.H. Smith. 1993. Evolution of mammalian social structure. Acta Theriologica 38, Suppl. 2:163-174.

1796 Novak, J.M., O.E. Rhodes Jr., M.H. Smith, and R.K. Chesser. 1993. Morphological asymmetry in mammals: Genetics and homeostasis reconsidered. Acta Theriologica 38, Suppl. 2:7-18.

1797 Bowling, J.W., J.E. Pinder III, R.F. Lide, K.A. Orlandini, and W.R. Penrose. 1994. Sedimentation flux of plutonium in a warm, monomictic reservoir. Journal of Environmental Radioactivity 22:111-126.

1798 Breshears, D.D., F.W. Whicker, and T.E. Hakonson. 1993. Orchestrating environmental research and assessment for remediation. Ecological Applications 3:590-594.

1799 Leff, L.G., J.V. McArthur, and L.J. Shimkets. 1993. Spatial and temporal variability of antibiotic resistance in freshwater bacterial assemblages. FEMS Microbiology Ecology 13:135-144. 
1800 Golley, F.B., J.E. Pinder III, P.J. Smallidge, and N.J. Lambert. 1994. Limited invasion and reproduction of loblolly pines in a large South Carolina old field. Oikos 69:21-27.

1801 Mills, M.S. and S.R. Yeomans. 1993. Heterodon platirhinos (Eastern hognose snake) diet. Herpetological Review 24:62.

1802 Weeks, S.C. and O.E. Gaggiotti. 1993. Patterns of offspring size at birth in clonal and sexual strains of Poeciliopsis (Poeciliidae). Copeia 1993:1003-1009.

1803 Burke, V.J., E.A. Standora, and S.J. Morreale. 1993. Diet of juvenile Kemp's ridley and loggerhead sea turtles from Long Island, New York. Copeia 1993:1176-1180.

1804 Layman, S.R. 1993. Life history of the Savannah darter, Etheostoma fricksium, in the Savannah River drainage, South Carolina. Copeia 1993:959-968.

1805 Belk, M.C. and L.S. Hales Jr. 1993. Predation-induced differences in growth and reproduction of bluegills (Lepomis macrochirus). Copeia 1993:1034-1044.

1806 Congdon, J.D., A.E. Dunham, and R.C. van Loben Sels. 1993. Delayed sexual maturity and demographics of Blanding's turtles (Emydoidea blandingii): Implications for conservation and management of long-lived organisms. Conservation Biology 7:826-833.

1807 Anderson, M.A. and P.M. Bertsch. 1993. Electrophoretic mobility and particle size of clays using laser doppler velocimetry-photon correlation spectroscopy. Soil Science Society of America Journal 57:1641-1643.

1808 Young, P.J., J.P. Megonigal, R.R. Sharitz, and F.P. Day. 1993. False ring formation in baldcypress (Taxodium distichum) saplings under two flooding regimes. Wetlands 13:293-298.

1809 Kramer, V.J. and M.C. Newman. 1994. Inhibition of glucosephosphate isomerase allozymes of the mosquitofish, Gambusia holbrooki, by mercury. Environmental Toxicology and Chemistry 13:9-14.

1810 Hartman, G.D. and J.D. Krenz. 1993. Estimating population density of moles Scalopus aquaticus using assessment lines. Acta Theriologica 38:305-314.

1811 Lydeard, C. and M.C. Belk. 1993. Management of indigenous fish species impacted by introduced mosquitofish: An experimental approach. The Southwestern Naturalist 38:370-373.

1812 Floyd, M.A. 1992. The biology and distribution of Oecetis larvae in North America (Trichoptera: Leptoceridae). Proceedings of the 7th International Symposium on Trichoptera 1992:87-91. 
1813 Winkelman, D.L. and J.M. Aho. 1993. Direct and indirect effects of predation on mosquitofish behavior and survival. Oecologia 96:300-303.

1814 Cooper, W.E., Jr. and N. Greenberg. 1992. Reptilian coloration and behavior. In Biology of the Reptilia, edited by C. Gans and D. Crews. p. 298-422. Volume 18, Physiology E. Hormones, Brain, and Behavior, edited by C. Gans. University of Chicago Press. Chicago, $\mathbb{I}$. (Reprints are not available for distribution at SREL. Book can be purchased from The University of Chicago Press, 5801 Ellis Avenue, Chicago, II 60637-1496).

1815 Fisher, S.K., C.H. Jagoe, C.E. Dallas, R.K. Chesser, M.H. Smith, and I.L. Brisbin Jr. 1993. Assessment of genetic damage as a biomarker in the remediation of contaminated or polluted sites. p. 629-634. In Proceedings of ER'93 Environmental Remediation Conference, U.S. Department of Energy. Washington, DC.

1816 Martin, H.W. and R.L. Brigmon. 1994. Biogeochemistry of sulfide oxidizing bacteria in phreatic karst. In Breakthroughs in Karst Geomicrobiology and Redox Geochemistry, edited by I.D. Sasowski and M.V. Palmer. Karst Waters Institute. Colorado Springs, CO.

1817 Brigmon, R.L., H.W. Martin, and S.G. Zam. 1994. Microbial ecology of Thiothrix spp. in the Floridan aquifer. p. 4-5. In Breakthroughs in Karst Geomicrobiology and Redox Geochemistry, edited by I.D. Sasowsky and M.V. Palmer. Karst Waters Institute. Colorado Springs, $\mathrm{CO}$.

1818 Rhodes, O.E., Jr., L.M. Smith, and R.K. Chesser. 1993. Temporal components of genetic variation in migrating and wintering American wigeon. Canadian Journal of Zoology 71:2229-2235.

1819 Carlson, C.L. and C.A. Carlson. 1994. Impacts of coal pile leachate on a forested wetland in South Carolina. Water, Air, and Soil Pollution 72:89-109.

1820 Smith, G.R., R.E. Ballinger, and J.D. Congdon. 1993. Thermal ecology of the high-altitude bunch grass lizard, Sceloporus scalaris. Canadian Journal of Zoology 71:2152-2155.

1821 Newman, M.C., M.M. Keklak, and M.S. Doggett. 1994. Quantifying animal size effects on toxicity: A general approach. Aquatic Toxicology 28:1-12.

1822 Burke, V.J., S.J. Morreale, and E.A. Standora. 1994. Diet of the Kemp's ridley sea turtle, Lepidochelys kempii, in New York waters. Fishery Bulletin 92:26-32.

1823 Kirkman, L.K. and R.R. Sharitz. 1994. Vegetation disturbance and maintenance of diversity in intermittently flooded Carolina bays in South Carolina. Ecological Applications 4:177-188. 
1824 Whicker, F.W., T.G. Hinton, D.J. Niquette, and J. Seel. 1993. Health risks to hypothetical residents of a radioactively contaminated lake bed. p. 619-624. In Proceedings of ER'93 Environmental Remediation Conference, U.S. Department of Energy. Washington, DC.

1825 Mahaney, P.A. 1994. Effects of freshwater petroleum contamination on amphibian hatching and metamorphosis. Environmental Toxicology and Chemistry 13:259-265.

1826 Rhodes, O.E., Jr. and R.K. Chesser. 1994. Genetic concepts for habitat conservation: The transfer and maintenance of genetic variation. Journal of Landscape and Urban Planning 28:55-62.

1827 Plummer, M.V. and J.D. Congdon. 1994. Radiotelemetric study of activity and movements of racers (Coluber constrictor) associated with a Carolina bay in South Carolina. Copeia 1994:20-26.

1828 Burke, V.J., N.B. Frazer, and J.W. Gibbons. 1993. Conservation of turtles: The Chelonian dilemma. p. 35-38. In Proceedings of the 13th Annual Symposium on Sea Turtle Biology and Conservation, U.S. Department of Commerce, National Oceanic and Atmospheric Administration. Jekyll Island, GA.

1829 Keeland, B.D. and R.R. Sharitz. 1993. Accuracy of tree growth measurements using dendrometer bands. Canadian Journal of Forest Research 23:2454-2457.

1830 Mulvey, M. and S.M. Bandoni. 1994. Genetic variability in the M-line stock of Biomphalaria glabrata (Mollusca: Planorbidae). Journal of the Helminthological Society of Washington 61:103-108.

1831 Meyer, A. and C. Lydeard. 1993. The evolution of copulatory organs, internal fertilization, placentae and viviparity in killifishes (Cyprinodontiformes) inferred from a DNA phylogeny of the tyrosine kinase gene $X$-src. Proceedings of the Royal Society (London) Series B 254:153-162.

1832 Purdue, J.R. and E.J. Reitz. 1993. Decrease in body size of white-tailed deer (Odocoileus virginianus) during the late Holocene in South Carolina and Georgia. In Morphological Change in Quaternary Mammals of North America, edited by R.A. Martin and A.D. Barnosky. p. 281-298. Cambridge University Press. Great Britain.

1833 Schnabel, A., J.L. Hamrick, and P.V. Wells. 1993. Influence of Quaternary history on the population genetic structure of Douglas-fir (Pseudotsuga menziesii) in the Great Basin. Canadian Journal of Forest Research 23:1900-1906. 
1834 Burke, V.J., J.W. Gibbons, and J.L. Greene. 1993. Prolonged nesting forays by common mud turtles (Kinosternon subrubrum). The American Midland Naturalist 131:190-195.

1835 Meffe, G.K. 1994. Human population control: The missing awareness. Conservation Biology 8:310-313.

1836 Hunter, D.B. and P.M. Bertsch. 1994. In situ measurements of tetraphenylboron degradation kinetics on clay mineral surfaces by IR. Environmental Science and Technology 28:686-691.

1837 Martin, H.W., D.A. Graetz, S.J. Locascio, and D.R. Hensel. 1994. Contrasts of nitrapyrin, dicyandiamide, and isobutylidene diurea effects on total inorganic soil nitrogen. Communications in Soil Science and Plant Analysis 25:547-565.

1838 Dunning, J.B., Jr. 1994. Tropical mass extinctions and the scientific method. Bulletin of the Ecological Society of America 75:44-45.

1839 Hinton, T.G. 1993. Sensitivity analysis of ECOSYS-87: An emphasis on the ingestion pathway as a function of a radionuclide and type of disposition. Health Physics 66:513-531.

1840 Dosskey, M.G. and P.M. Bertsch. 1994. Forest sources and pathways of organic matter transport to a blackwater stream: A hydrologic approach. Biogeochemistry 24:1-19.

1841 McArthur, J.V., J.M. Aho, R.B. Rader, and G.L. Mills. 1994. Interspecific leaf interactions during decomposition in aquatic and floodplain ecosystems. Journal of the North American Benthological Society 13:57-67.

1842 Leff, L.G. and J.V. McArthur. 1994. Effect of macroinvertebrates on detachment of bacteria from biofilms in stream microcosms. Journal of the North American Benthological Society 13:74-79.

1843 Krenz, J.D. and D.E. Scott. 1994. Terrestrial courtship affects mating locations in Ambystoma opacum. Herpetologica 50:46-50.

1844 Pechmann, J.H.K. and H.M. Wilbur. 1994. Putting declining amphibian populations in perspective: Natural fluctuations and human impacts. Herpetologica 50:65-84.

1845 Bildstein, K.L., D.E. Gawlik, D.P. Ferral, I.L. Brisbin Jr., and G.R. Wein. 1994. Wading bird use of established and newly created reactor cooling reservoirs at the Savannah River Site, near Aiken, South Carolina, USA. Hydrobiologia 279/280:71-82. 
1846 Bertsch, P.M., D.B. Hunter, S.R. Sutton, S. Bajt, and M.L. Rivers. 1994. In situ chemical speciation of uranium in soils and sediments by micro $\mathrm{X}$-ray absorption spectroscopy. Environmental Science and Technology 28:980-984.

1847 Brisbin, I.L., Jr. 1990. Growth curve analyses and their application to the conservation and captive management of crocodilians. p. 116-145. In Proceedings of the Ninth Working Meeting of the Crocodile Specialist Group, edited by F.W. King. Vol. 1. SSC/IUCN. Gland, Switzerland.

1848 Wolff, J.O. 1994. Reproductive success of solitarily and communally nesting white-footed mice and deer mice. Behavioral Ecology 5:206-209.

1849 Ford, N.B. and R.A. Seigel. 1994. An experimental study of the trade-offs between age and size at maturity: Effects of energy availability. Functional Ecology 8:91-96.

1850 Meffe, G.K. and F.F. Snelson Jr. 1993. Lipid dynamics during reproduction in two livebearing fishes, Gambusia holbrooki and Poecilia latipinna. Canadian Journal of Fisheries and Aquatic Sciences 50:2185-2191.

1851 Keklak, M.M., M.C. Newman, and M. Mulvey. 1994. Enhanced uranium tolerance of an exposed population of Eastern mosquitofish (Gambusia holbrooki Girard 1859). Archives of Environmental Contamination and Toxicology 27:20-24.

1852 Grant, B.W., K.L. Brown, G.W. Ferguson, and J.W. Gibbons. 1994. Changes in amphibian biodiversity associated with 25 years of pine forest regeneration: implications for biodiversity management. In Biological Diversity: Problems and Challenges, edited by S.K. Majumdar, F.J. Brenner, J.E. Lovich, J.F. Schalles, and E.W. Miller. p. 355-367. The Pennsylvania Academy of Science.

1853 Kaplan, D.I., D.B. Hunter, P.M. Bertsch, S. Bajt, and D.C. Adriano. 1994. Application of synchrotron $\mathrm{X}$-ray fluorescence spectroscopy and energy dispersive $\mathrm{x}$-ray analysis to identify contaminant metals on groundwater colloids. Environmental Science and Technology 28:1186-1189.

1854 Mulvey, M., J.M. Aho, and O.E. Rhodes Jr. 1994. Parasitism and white-tailed deer: Timing and components of female reproduction. Oikos 70:177-182.

1855 White, T.D. and R.A. Anderson. 1994. Locomotor patterns and costs as related to body size and form in teiid lizards. Journal of Zoology 233:107-128.

1856 Smith, M.H., K.B. Willis, and P.E. Johns. 1990. Spatial-genetic variation in a white-tailed deer herd. p. 80-84. In Transactions of the 19th International Union of Game Biologists, IUGB. Trondheim. 
1857 Jones, R.H., D.S. Segal, and R.R. Sharitz. 1994. Cation dynamics in bottomland hardwood forest litter. American Midland Naturalist 131:248-256.

1858 Newman, M.C. and C.H. Jagoe. 1994. Ligands and the bioavailability of metals in aquatic environments. p. 39-61. In Bioavailability: Physical, Chemical and Biological Interactions, edited by J.L. Hamelink, P.F. Landrum, H.L. Bergman, and W.H. Benson. Lewis Publishers, Inc. Proceedings of the Thirteenth Pellston Workshop, Pellston, MI.

1859 Belk, M.C. and C. Lydeard. 1994. Effect of Gambusia holbrooki on a similar-sized, syntopic Poeciliid, Heterandria formosa: Competitor or predator? Copeia 1994:296-302.

1860 Scribner, K.T., J.D. Congdon, R.K. Chesser, and M.H. Smith. 1993. Annual differences in female reproductive success affect spatial and cohort-specific genotypic heterogeneity in painted turtles. Evolution 47:1360-1373.

1861 Loehle, C. and G. Wein. 1994. Landscape habitat diversity: A multiscale information theory approach. Ecological Modelling 73:311-329.

1862 Benson, W.H., J.J. Alberts, H.E. Allen, C.D. Hunt, and M.C. Newman. 1994. Synopsis of discussion session on the bioavailability of inorganic contaminants. p. 63-71. In Bioavailability: Physical. Chemical and Biological Interactions, edited by J.L. Hamelink, P.F. Landrum, H.L. Bergman, and W.H. Benson. Lewis Publishers, Inc. Proceedings of the Thirteenth Pellston Workshop, Pellston, MI.

1863 McDonald, M.A. and M.H. Smith. 1994. Behavioral and morphological correlates of heterochrony in Hispaniolan Palm-Tanagers. The Condor 96:433-446.

1864 Brisbin, I.L., Jr., R.P. Coppinger, M.H. Feinstein, S.N. Austad, and J.J. Mayer. 1994. The New Guinea Singing Dog: Taxonomy, captive studies and conservation priorities. Science in New Guinea 20:27-38.

SRO-NERP-22 Davis, G. M. and M. E. Mulvey. 1993. Species Status of Mill Creek Elliptio. University of Georgia's Savannah River Ecology Laboratory. Publication of the Savannah River National Environmental Research Program. Aiken, SC. 


\section{B. Journal Articles and Book Chapters In Press}

Adriano, D. C., J. Albright, F. W. Whicker, and I. K. Iskandar. Remediation of metal and radionuclide-contaminated soil. Special volume from the Second International Conference on the Biogeochemistry of Trace Elements, Remediation of Metal Contaminated Soils. Applied Science Publishers, London.

Adriano, D. C. and M. Chino. Biogeochemical aspects of lead, germanium, and tin. Main Group Metal Chemistry.

Adriano, D.C. and M.A. Elrashidi. Interactions of contaminants with soil components and environmental restoration. In Conference Proceedings of the International Soil Science Society, International Soil Science Society.

Anderson, R.A. Functional and population responses of the lizard Cnemidophorus tigris to environmental fluctuations. American Zoologist .

Bandoni, S.M., M. Mulvey, and E.S. Loker. Intraspecific and interspecific patterns of allozyme variation among species of Biomphalaria Preston, 1910 (Gastropoda: Planorbidae). Biochemical Systematics and Ecology .

Bandoni, S.M., M. Mulvey, and E.S. Loker. Phylogenetic analysis of eleven species of Biomphalaria Preston, 1910 (Gastropoda: Planorbidae) based on comparisons of allozymes. Biological Journal of the Linnean Society .

Boileau, M.G. and B.E. Taylor. Chance events, habitat age, and the genetic structure of pond populations. Archiv für Hydrobiologie .

Brigmon, R.L., H.W. Martin, T.L. Morris, G. Bitton, and S.G. Zam. Biogeochemical ecology of Thiothrix spp. in underwater limestone caves. Proceedings from the symposium: Breakthroughs in Karst Geomicrobiology. Geomicrobiology Journal.

Brisbin, I. L., Jr. Birds as monitors of radionuclide contamination. In Birds as Monitors of Environmental Change, edited by F. W. Furness. Chapman and Hall, London.

Brisbin, I.L., Jr. A review: Pigs: A Handbook to the Breeds of the World, by Valerie Porter. Journal of Mammalogy.

Brisbin, I. L., Jr., J. M. Benner, L. A. Brandt, R. A. Kennamer, and T. M. Murphy. Longterm population studies of American alligators inhabiting a reservoir: Initial responses to water level drawdown. p. 53-76. In Crocodiles - Proceedings of the 11th Working Meeting of the Crocodile Specialist Group of the SSC of the IUCN -The World Conservation Union, Vol. 1 IUCN. Victoria Falls, Zimbabwe.

Bryan, A. L., Jr., M. C. Coulter, and C. J. Pennycuick. Foraging strategies and energetic costs of foraging flights by breeding Wood Storks. Condor. 
Bryan, A.L., Jr., T.M. Murphy, K.L. Bildstein, I.L. Brisbin Jr., and J.J. Mayer. Use of reservoirs and other artificial impoundments by Bald Eagles in South Carolina. Journal of Raptor Research.

Bryan, A.L., Jr., M.C. Coulter, and C.J. Pennycuick. Strategies and energetic costs of foraging travel by breeding wood storks. The Condor .

Bryce, A. L., W. A. Kornicker, A. L. Elzerman, and S. B. Clark. Nickel (II) interactions with hydrous ferric oxide surfaces in the presence of EDTA. Environmental Science and Technology.

Burke, V. J., J. L. Greene, and J. W. Gibbons. The effect of sample size and study duration on metapopulation estimates for slider turtles (Trachemys scripta). Herpetologica.

Chesser, R.K., R.J. Bradley, R.A. Van Den Bussche, M.J. Hamilton, and R.J. Baker. Maintenance of a narrow hybrid zone in Geomys: Results from contiguous clustering analysis. In Festshrift for J. Knox Jones, Jr.

Congdon, J.D., T.E. Graham, and B. Brecke. Emydoidea blandingii (Holbrook, 1842), Blanding's turtle. In I.U.C.N. Handbook - Conservation of Fresh Water Turtles .

Congdon, J.D., A.E. Dunham, and R.C. van Loben Sels. Demographics of common snapping turtles (Chelydra serpentina): Implications for conservation and management of long-lived organisms. American Zoologist .

Congdon, J.D. and A.E. Dunham. Contributions of long-term life history studies to conservation biology. In Principles of Conservation Biology, edited by G.K. Meffe and C.R. Carroll. Sinauer Associates. New York.

Cook, A.E. and J.E. Pinder III. Relative accuracy of rectifications using coordinates determined from maps and global positioning systems. Photogrammetric Engineering and Remote Sensing.

Coulter, M. C. and A. L. Bryan, Jr. The design and management of the Kathwood ponds: Artificial foraging ponds for Wood Storks from east-central Georgia. The Savannah Wood Stork Symposium.

Dallas, C.E., C.H. Jagoe, S.K. Fisher, K.A. Holloman, R.K. Chesser, M.H. Smith, and M. Lomakin. Evaluation of genotoxicity in wild organisms due to the Chernobyl nuclear disaster. In Animal World and Ecosystems in Conditions of Radioactive Pollution, Nauka Science Publishers. Russian Academy of Sciences, Moscow.

DeCourcy, K. R. and T. A. Jenssen. Structure and use of male territorial headbob signals by the lizard, Anolis carolinensis. Animal Behavior. 
Dixon, P. Testing spatial segregation using a nearest-neighbor contingency table. Ecology.

Dunning, J.B., Jr., R. Borgella Jr., K. Clements, and G.K. Meffe. Patch isolation, corridor effects, and avian colonization of habitat patches in a managed pine woodland. Conservation Biology.

Edwards, A. E., R. Wyatt, and R. R. Sharitz. Seed buoyancy and viability of the wetland milkweed Asclepias perennis and an upland milkweed, Asclepias exaltata. Bulletin of the Torrey Botanical Club.

Fischer, R.U., D.E. Scott, J.D. Congdon, and S.A. Busa. Mass dynamics during embryonic development in cottonmouth neonates. Journal of Herpetology.

Fisher, S. K., C. E. Dallas, C. H. Jagoe, M. H. Smith, I. L. Bribin, Jr. and R. K. Chesser. Sources of error associated with sample collection and preparation of nucleated blood cells for flow cytometric analysis. Cell Biology and Toxicology.

Fisher, S.K., J.T. Lingenfelser, C.H. Jagoe, and C.E. Dallas. Evaluation of the effects of cryopreservation of isolated erythrocytes and leukocytes of largemouth bass (Micropterus salmoides) by flow cytometry. Journal of Fish Biology.

Frazer, N.B. Five year status review of the loggerhead sea turtle (Caretta caretta) under the Endangered Species Act of 1973. U.S. Fish and Wildlife Service, Albuquerque, NM.

Frazer, N.B. Hatcheries and headstarting programs. In Principles of Conservation Biology, edited by G.K. Meffe and C.R. Carroll. Sinauer Associates. New York.

Gibbons, J.W. and D.R. Jackson. Deirochelys reticularia (Latreille, in Sonnini and Latreille, 1801) Chicken turtle. In Conservation Biology of Freshwater Turtles,

Gibbons, J.W. Management of the desert tortoise and other reptiles and amphibians: Time for an environmental attitude adjustment. In Desert Tortoise Council Meeting, Las Vegas, NV.

Gibbons, J.W. Reproductive patterns of reptiles and amphibians: Considerations for captive breeding and conservation. In Captive Management and Conservation of Amphibians and Reptiles, A Volume Honoring_Roger Conant, edited by J.B. Murphy, J.T. Collins, and K. Alder.

Gibbons, J.W. and M.W. Klemens. Kinosternon subrubrum (Lacepede) mud turtle. In The Conservation Biology of Freshwater Turtles. 
Haines, T.A., V.L. Komov, and C.H. Jagoe. Mercury concentration in perch (Perca fluviatilis) as influenced by lacustrine physical and chemical factors in two regions of Russia. In Mercury as a Global Pollutant, edited by C. Watras and J. Huckabee. Lewis Publishers. Chelsea, MI..

Haines, T., V. Komov, C. Jagoe, and V. Matey. Mercury content and ultrastructure of gills and scales of fish from lakes in north and northwestern Russia that are polluted by atmospheric deposition. In Fate and Effects of Pollutants in Aquatic Organisms and Ecosystems, edited by R. Schoettger and N. Smirov. Institute for the Biology of Inland Waters, Borok Russia. U.S. EPA Research Report Series.

Hardegree, W.S., D.B. Wenner, J.F. Dowd, and K.W. McLeod. Using ${ }^{18} \mathrm{O} /{ }^{16} \mathrm{O}$ ratios to identify the extent of backwater inundation of wetlands. Wetland Ecology and Management.

Hartman, G.D. Age determination, age structure, and sex ratio in the mole, Scalopus aquaticus (Mammalia: insectora). Journal of Mammalogy.

Herbert, B.E. and P.M. Bertsch. Characterization of dissolved and colloidal organic matter in soil solution: A review. Soil Organic Carbon: Soil Science Society of America Journal Special Publication.

Heulett, S.T., S.C. Weeks, and G.K. Meffe. Lipid dynamics and growth relative to resource level in juvenile eastern mosquitofish (Gambusia holbrooki: Poeciliidae). Copeia.

Hinton, T. G. and F. W. Whicker. A screening model approach to determine probable impacts to fish from historic releases of radionuclides. Science of the Total Environment.

Imm, D. W. and J. S. Clark. Geographic and climatic influences on tree species abundance within the Eastern Deciduous Forest. Vegetatio.

Imm, D. W., K. W. McLeod, S. W. Workman, and P. Camill. Eleven years of post-fire change in summer and winter burned sandhill ridges of the upper Coastal Plain. Bulletin of the Torrey Botanical Club.

Jenssen, T.A. and S.C. Nunez. Male and female reproductive cycle of the Jamaican lizard, Anolis opalinus. Copeia.

Jenssen, T.A. and S. Nunez. Male and female reproductive cycles of the Jamaican lizard, Anolis opalinus. Copeia. 
Johnson, W.H., S.M. Serkiz, and S.B. Clark. Determination of site specific distribution coefficients of mixed waste contaminants using an in-situ approach. In Proceedings of the 27th Midyear Topical Meeting of the Health Physics Society: Managing Radioactive and Mixed Wastes, Health Physics Society. Albany, NY.

Jones, R.H., R.R. Sharitz, S.M. James, and P.M. Dixon. Tree population of dynamics in seven South Carolina mixed-species forests. Bulletin of the Torrey Botanical Club.

Jones, R. H., R. R. Sharitz, P. M. Dixon, D. S. Segal, and R. L. Schneider. Woody plant regeneration in four floodplain forests. Ecological Monographs.

Kaplan, D. I., P. M. Bertsch, D. C. Adriano, and K. Orlandini. Actinide association with groundwater colloids in a Coastal Plain aquifer. Radiochimica Acta.

Lamb, T., C. Lydeard, R.B. Walker, and J.W. Gibbons. Molecular systematics of the map turtles (Graptemys): A comparison of mitochondrial restriction site versus sequence data. Systematic Biology.

Leberg, P.L., P. Stangel, H. Hillestad, L. Marchinton, and M.H. Smith. Genetic structure of reintroduced wild turkey and white-tailed deer populations. Journal of Wildlife Management.

Leff, L.G. Stream bacterial ecology: A neglected field? ASM News.

Lovich, J. E. Biodiversity and zoogeography of non-marine turtles in southeast Asia. In Biological Diversity: Problems and Challenges, edited by S. K. Majumdar, F. J. Brenner, J. E. Lovich, J. F. Schalles, and E. W. Miller. p. 380-391. The Pennsylvania Academy of Science.

Lydeard, C., M.C. Wooten, and A. Meyer. Molecules, morphology and area cladograms: a cladistic and biogeographic analysis of Gambusia (Teleostei: poeciliidae). Systematic Biology.

Martin, H. W. More on beautyberry. Palmetto.

Martin, H. W. and W. G. Harris. Mineralogy of clay sediments in three phreatic caves of the Suwannee River Basin. The National Speleological Society Bulletin.

Martin, H.W. and W.C. Liebhardt. Tomato response to long term $\mathrm{K}$ and lime on a soil high in nonexchangeable $\mathrm{K}$. Journal of Plant Nutrition.

Matey, V.E., C.H. Jagoe, T.A. Haines, V.T. Komov, and L. Cleveland. Mortality and gill damage due to beryllium in acidic water: A comparison of acute and chronic responses in three freshwater fish species (Perca fluviatilis, Perca flavescens, and Rutilus rutilus). In Fate and Effects of Pollutants in Aquatics Ecosystems. 
Proceedings of a US-Russia Symposium, edited by R. Schoettger and N. Smirnov. Institute for the Biology of Inland Waters, Borok, Russia. U.S. EPA Research Report Series.

McAlpine, S., O.E. Rhodes Jr., C.D. McCreedy, and I.L. Brisbin Jr. Genetic structure in a wintering population of American Coots (Fulica americana). Wilson Bulletin.

McCloskey, J. T. and M. C. Newman. Asiatic clam (Corbicula fluminea) and viviparid snail (Campeloma decisum) sediment preference as a sublethal response to low level metal contamination. Archives of Environmental Contamination and Toxicology.

McCloskey, J. T., M. C. Newman, and P. M. Dixon. Effect of metal contaminated sediment on the distribution of the asiatic clam, Corbicula fluminea populations. Archives of Environmental Contamination and Toxicology.

Meffe, G.K. Genetic and ecological guidelines for species reintroduction programs. Journal of Great Lakes Research.

Meffe, G.K. Conserving genetic diversity in natural systems. In Biodiversity in Managed Landscapes, Oxford University Press.

Meffe, G.K. Conservation biology, salmon recovery, and the "real world". In 1992 Northeast Pacific Chinook and Coho Workshop, Boise, ID.

Mills, M.S. and C.J. Hudson. Nerodia taxispilota (brown water snake). Diet. Herpetological Review.

Moorhead, K.K. and M.M. Brinson. Response of wetlands to rising sea level in the lower coastal plain of North Carolina. Ecological Applications.

Moorhead, K.K. and R.A. Nordstedt. Batch anaerobic digestion of water hyacinth: Effects of particle size, plant nitrogen content, and inoculum volume. Bioresource Technology.

Morreale, S.J. and V.J. Burke. Conservation and biology of sea turtles in the northeastern United States. In Book - Conservation and Biology of Northeastern Turtles,

Mulvey, M., G.P. Keller, and G.K. Meffe. Single- and multiple-locus genotypes and life history responses of Gambusia holbrooki reared at two temperatures. Evolution.

Newman, M. C. Quantitative ecotoxicology of metals in aquatic systems. Proceedings of the U.S. EPA/Israel Ministry of Environment Workshop on Monitoring and Modeling Water Quality. Haifa, Israel. 
Newman, M. C. and R. M. Jagoe. Bioaccumulation models with time lags: Dynamics and stability criteria. Ecological Modelling.

Newman, M. C., M. Mulvey, A. Beeby, R. W. Hurst, and L. Richmond. Snail (Helix aspersa) exposure history and possible adaptation to lead as reflected in shell composition. Archives of Environmental Contamination and Toxicology.

Niewiarowski, P. Effects of supplemental feeding and thermal environment on growth rates of eastern fence lizards, Sceloporus undulatus. Herpetologica.

Niewiarowski, P. H. and A. E. Dunham. The evolution of reproductive effort in squamate reptiles: Costs, trade-offs and assumptions reconsidered. Evolution.

Onken, B.M. and L.R. Hossner. Plant uptake and determination of arsenic species in soil solution under flooded conditions. Journal of Environmental Quality.

Page, R.D.M. and C. Lydeard. Towards a cladistic biogeography of the Caribbean. Cladistics.

Pinder, J.E., III, J.W. Bowling, R.L. Lide, and L.B. Oliver. The distribution of ${ }^{137} \mathrm{Cs}$ in sediments of the littoral zone of a former reactor cooling pond. Journal of Environmental Radioactivity.

Rader, R. B. and J V. McArthur. The relative importance of refugia in determining the drift and habitat selection of predacious stoneflies in a sandy-bottom stream. Oecologia.

Rao, L.F., G.R. Choppin, and S.B. Clark. A study of metal-humate interactions using cation exchange. Radiochimica Acta.

Ratnaswamy, M.J., C.L. Rogers, R.J. Warren, M.H. Smith, and K.A.K. Stromayer. Electrophoretic comparison of road-killed deer and live-captured deer sampled by muscle biopsy. In Proceedings of the Annual Conference of the Southeastern Association of Fish and Wildlife Agencies.

Rhodes, O.E., Jr. and R.S. Johns. Relationships between heterozygosity and conception date in white-tailed deer from South Carolina. XXI International Union of Game Biologists Congress.

Schierenbeck, K.A., R.N. Mack, and R.R. Sharitz. Effects of herbivory on growth and biomass allocation in native and introduced species of Lonicera. Ecology.

Schultz, I.R. and W.L. Hayton. Body size and the toxicokinetics of trifluralin in rainbow trout. Toxicology and Applied Pharmacology. 
Scott, D. E. The effect of larval density on adult demographic traits in Ambystoma opacum. Ecology.

Scribner, K. T. and J. C. Avise. Cytonuclear genetics of experimental fish hybrid zones inside Biosphere 2. Proceedings of the National Academy of Science.

Scribner, K. T. and J. C. Avise. Population cage experiments with a vertebrate: The temporal demography and cytonuclear genetics of hybridization in Gambusia fishes. Evolution.

Sheldon, A. L. and G. K. Meffe. Multivariate analysis of feeding relationships of fishes in blackwater streams. Environmental Biology of Fishes.

Smith, M.H. and O.E. Rhodes Jr. Subspecies of the white-tailed deer. In Deer, Stackpole Books.

Smith, M.H. and O.E. Rhodes Jr. Genetic applications in wildlife management: An introduction. In XXI International Union of Game Biologists Congress, IUGB. Halifax, Nova Scotia.

Staton, M.A., H.M. Edwards Jr., I.L. Brisbin, T. Joanen, and L. McNease. The influence of environmental temperature and dietary factors on utilization of dietary energy and protein in purified diets by alligators, Alligator mississippiensis (Daudin). Aquaculture.

Sugg, D. W. and R. K. Chesser. Effective population sizes with multiple paternity. Genetics.

Sugg, D.W., R.K. Chesser, J.A. Brooks, and B.T. Grasman. The association of DNA damage to concentrations of mercury and radiocesium in largemouth bass. Environmental Toxicology and Chemistry.

Tuberville, T.D. and V.J. Burke. Do flag markers attract turtle nest predators? Journal of Herpetology.

van Staaden, M., R.K. Chesser, and G.R. Michener. Genetic correlations and matrilineal structure in a population of Spermophilus richardsonii. Journal of Mammalogy.

Voelz, N. J., N. L. Poff, and J. V. Ward. Differential effects of a brief thermal disturbance on caddisflies (Trichoptera) in a regulated river. The American Midland Naturalist.

Weeks, S.C. Comparisons of life-history traits between clonal and sexual fish (Poeciliopsis: Poeciliidae) raised in monoculture and mixed treatments. Evolutionary Ecology. 
Whicker, F. W., T. G. Hinton, and D. J. Niquette. The effects of a partial drawdown on the dynamics of ${ }^{137} \mathrm{Cs}$ in an abandoned reactor cooling reservoir. Science of the Total Environment.

White, J.D., G.C. Kroh, and J.E. Pinder II. Mapping forest species at Lassen Volcanic National Park, California, using Landsat Thematic Mapper Data and a Geographical Information System. Photogrammetric Engineering and Remote Sensing.

Young, P.J., B.D. Keeland, and R.R. Sharitz. Growth response of baldcypress (Taxodium distichum (L.) Rich.) to an altered hydrologic regime. The American Midland Naturalist. 


\section{Books Published and In Press}

Gibbons, J. W. 1993. Keeping All the Pieces. Smithsonian Institution Press, Washington, DC.

Keefer, R. F. and K. S. Sajwan (eds.). 1993. Trace Elements in Coal and Coal Combustion Residues. Lewis Publishers, Inc. Boca Raton, FL.

Meffe, G. K. and C. R. Carroll. 1994. Principles of Conservation Biology. Sinauer Associates. Sunderland, MA.

Adriano, D. C. (ed.). Biogeochemistry of Trace Metals 2. Science Reviews, Ltd., London (in press).

Adriano, D. C., I. K. Iskandar and I. Murarka (eds.). Groundwater Contamination. Science Reviews, Ltd., London (in press).

Iskandar, I. K. and D. C. Adriano (eds.). Remediation of Metal-Contaminated Soils. Science Reviews, Ltd., London (in press).

Newman, M. C. Quantitative Methods in Aquatic Ecotoxicology. Lewis Publishers, Chelsea, MI. (in press).

Rhodes, O. E., R. K. Chesser and M. H. Smith (eds.). Spatial and Temporal Aspects of Population Processes. University of Chicago Press, Chicago, II. (in press). 


\section{Presentations}

Adriano, D. C. Invited Speaker. Remediation of metal- and radionuclide-contaminated soil. Second International Conference on the Biogeochemistry of Trace Elements. Taipei, Taiwan. September 1993.

Adriano, D. C. Soil remediation: Science, technology and applications. American Society of Agronomy, Crop Science Society of America, Soil Science Society of America Annual Meetings. Cincinnati, OH. November 1993.

Adriano, D. C. Invited Speaker. Remediation of contaminated soil: Science, technology and applications. Special Symposium on Contaminated Land, American Society of Agronomy. Cincinnati, OH. November 1993.

Adriano, D. C. Invited Speaker. Remediation of metal and radionuclide contaminated soils. DuPont Central Experiment Station, Site 300. Newark, DE. March 1994.

Adriano, D. C. Invited Speaker. Interactions of contaminants with soil components and environmental restoration. 15th World Congress of Soil Science. Acapulco, Mexico. July 1994.

Arnold, R. L. and W. P. Miller. Dispersibility of fly-ash amended southeastern U.S. soils. American Society of Agronomy Annual Meeting. Cincinnati, OH. November 1993.

Aspit, V. and P. M. Dixon. Genetic variation in a declining plant species. Southeastern Population Ecology and Ecological Genetics Group Meeting. Camp Sertoma, NC. September 1993.

Basham, M., G. C. Kroh, and J. E. Pinder. Mapping vegetation communities in Lassen Volcanic National Park, CA using Landstat TM and SPOT XS data. U.S. Geological Survey, U.S. Environmental Protection Agency, National Aeronautics and Space Administration, National Oceanic and Atmospheric Administration.. Sioux Falls, SD. August 1993.

Battaglia, L. and D. W. Pritchett. Community structure and biomass production during early secondary succession in a Louisiana floodplain. Ecological Society of America Annual Meeting. Madison, WI. August 1993.

Bertram, T. E., D. E. Funsch, and J. E. Pinder. Deforestation and forest fragmentation in the Upper Coastal Plain of Georgia and South Carolina. University of Arizona U.S. Landscape Ecology Symposium. Tucson, AZ. March 1994.

Bertram, T. E., D. Funsch, and J. E. Pinder. Deforestation and forest fragmentation in the Upper Coastal Plain of Georgia and South Carolina. Association of Southeastern Biologists Annual Meeting. Orlando, FL. April 1994.

Bertsch, P. M., D. B. Hunter, and J. R. Shann. Elucidation of differentially adsorbed Al environments on genetically diverse triticum cell wall preparations. Third International Symposium on Plant-Soil Interactions at Low pH. Brisbane, Australia. September 1993.

Bertsch, P. M., D. B. Hunter, and J. R. Shann. Elucidation of differentially adsorbed Al environments on genetically diverse triticum cell wall preparations. International Conference on Acid Soils. Coolum, Australia. September 1993.

Bertsch, P. M. and D. B. Hunter. Invited Speaker. Structural environments of Cs adsorbed to clay minerals and model exchangers. Soil Science Society of America National Meetings. Cincinnati, OH. November 1993. 
Bertsch, P. M., D. B. Hunter, S. R. Sutton, S. Bajt, and M. L. Rivers. Invited Speaker. In situ chemical speciation of uranium in soils by micro $\mathrm{x}$-ray absorption spectroscopy. Soil Science Society of America Annual Meeting. Cincinnati, OH. November 1993.

Bertsch, P. M. Invited Seminar. Physicochemical controls on colloid generation and mobility in surface and subsurface environments. Lawrence Berkeley Laboratory, University of California. Berkeley, CA. November 1993.

Bertsch, P. M. Invited Speaker. Chemical controls on contaminant migration in the subsurface. Hydroecology. University of South Carolina. Columbia, SC. November 1993.

Bertsch, P. M. and D. B. Hunter. $\mathrm{Cs}^{+}$adsorption environments on model and mineral exchangers as revealed by ${ }^{133} \mathrm{Cs}$ NMR and Cs EXAFS. Migration '93 Conference. Charleston, SC. December 1993.

Bertsch, P. M. and D. B. Hunter. Invited Speaker. Applications of synchrotron radiation in environmental sciences. North Carolina State University. Raleigh, NC. April 1994.

Brisbin, I. L., T. G. Hinton, C. H. Jagoe, E. L. Peters, C. E. Dallas. Invited Speaker. The principles of radioecology. Short course. Society of Environmental Toxicology and Chemistry Annual Meeting. Houston, TX. November 1993.

Brisbin, I. L., Jr. Studying pigs to save sea turtles: The value of knowing your enemies. 1994 Sea Turtle Symposium. Hilton Head, SC. March 1994.

Brisbin, I. L., Jr. Invited Speaker. From the wild to the barnyard and back again: A plea for conservation concerns. Association of Zooculturists Annual Meeting. Pensacola, FL. March 1994.

Brisbin, I. L., Jr. Invited Speaker. The Ossabaw pig - Ecology and conservation. American Minor Breeds Conservancy Annual Meeting. Savannah, GA. March 1994.

Brisbin, I. L., Jr. Invited Speaker. From the wild to the barnyard and back again: conservation priorities for the wild ancestors and feral counterparts of our common domestic animals, and making scents out of canine olfaction. College of Veterinary Medicine, Cornell University. Ithaca, NY. April 1994.

Brisbin, I. L., Jr., N. J. Casna, T. M. Murphy, and J. Aikin. Genomic DNA comparisons of bald eagies from southeastern and northwestern North America. 122th Meeting of the American Ornithologists' Union. Missoula, MT. June 1994.

Bryan, A. L., Jr. and I. L. Brisbin, Jr. Invited Speaker. Recent findings in the U.S. DOE Program of Research and Habitat-Loss Mitigation for the American Wood Stork at the Savannah River Site. The Georgia Conservancy Wood Stork Symposium. Savannah, GA. October 1993.

Bryan, A. L., Jr., T. M. Murphy, K. Bildstein, I. L. Brisbin, Jr. and J. J. Mayer. Use of reservoirs and other artificial impoundments by bald eagles in the southeastern United States. Raptor Research Foundation Annual Meeting. Charlotte, NC. November 1993.

Bryan, A. L. and T. V. Youngblood. Factors affecting recent use of artificial foraging ponds by wood storks. 122th Meeting of the American Ornithologists' Union. Missoula, MT. June 1994.

Buhlmann, K. A. Invited Speaker. Conservation strategies for rare freshwater turtles in Virginia. The Virginia Herpetological Society and Liberty University. Lynchburg, VA. October 1993. 
Buhlmann, K. A. and J. W. Gibbons. Invited Speaker. Aquatic fauna in peril: A Historical perspective of reptiles. Tennessee Aquarium. Chattanooga, TN. March 1994.

Buhlmann, K. A. and J. W. Gibbons. Invited Speaker. Conservation issues with reptiles. Tennessee Aquarium. Chattanooga, TN. April 1994.

Buhlmann, K. A., T. K. Lynch, J. W. Gibbons, and J. L. Greene. Prolonged egg retention in the chicken turtle. Joint meeting of the Herpetologists' League and the Society for the Study of Amphibians and Reptiles. Athens, GA. July 1994.

Burke, V. J. Prolonged nesting by common mud turtles, Kinosternon subrubrum. Society for the Study of Amphibians and Reptiles Annual Meeting. Bloomington, IN. August 1993.

Burke, V. J. and J. W. Gibbons. Reevaluating wetland conservation policies with GIS models of habitat use by aquatic turtles. Association of Southeast Biologists Annual Meeting. Orlando, FL. April 1994.

Burke, V. J. Invited Speaker. Buffer zones for freshwater turtles. Gopher Tortoise Council. St. Petersburg, FL. April 1994.

Burke, V. J., J. L. Greene, and J. W. Gibbons. The effects of sample size and study duration on metapopulation estimates for slider turtles. Joint meeting of the Herpetologists' League and the Society for the Study of Reptiles and Amphibians. Athens, GA. July 1994.

Burrows, D. R. Scientific ethics - A primer for the quality professional. National Energy and Environmental Quality Division Conference Annual Meeting. Indian Wells, CA. September 1993.

Burrows, D. R. Quality metrics projects at three DOE laboratories. American Society for Quality Control Annual Eastern Energy Environmental Quality Conference. Durham, NC. March 1994.

Chesser, R. K. Invited Speaker. Conservation of gene diversity. Institute of Ecology, University of Georgia. Athens, GA. September 1993.

Chesser, R. K. Invited Speaker. Chernobyl. Texas Tech University. Lubbock, TX. October 1993.

Chesser, R. K. Invited Speaker. Sociological and ecological legacies of the Chernobyl nuclear accident. Western Oklahoma State College. Altus, OK. October 1993.

Chesser, R. K. Invited Speaker. The social and ecological impacts of the Chernobyl accident. Crichton College. Memphis, TN. November 1993.

Chesser, R. K. Invited Speaker. Ecology of the Chernobyl Exclusion Zone. Memphis State University. Memphis, TN. November 1993.

Chesser, R. K. Invited Speaker. Sociological and ecological legacy of the Chernobyl nuclear accident. Memphis State University. Memphis, TN. November 1993.

Chesser, R. K. Invited Speaker. Evolution in social systems. Howard Hughes Medical Institute. March 1994.

Chesser, R. K. Invited Speaker. Ecological and sociological consequences of the Chernobyl disaster. Oklahoma State College. Lawton, OK. March 1994.

Chesser, R. K. and D. Sugg. Invited Speaker. Toxicants as selective agents in population and community dynamics. Savannah River Symposia on Environmental Science "Quantitative Ecotoxicology: A Hierarchical Approach." Aiken, SC. June 1994. 
Clark, S. B., S. Bajt, S. R. Sutton, D. B. Hunter, M. Rivers, and C. A. Langton. In-situ quantification of trace metal species in matrices of environmental interest. American Chemical Society National Meeting's International Symposium on Advances in Environmental Analytical Chemistry. Chicago, IL. August 1993.

Clark, S. B., B. E. Stout, and B. Helmer. EXAFS studies of polynuclear uranium (VI) complexes in carbonate, chloride, hydroxide, and nitrate solutions. Actinides-93 International Conference. Santa Fe, NM. September 1993.

Clark, S. B., S. Bajt, C. A. Langton, S. R. Sutton, and M. Rivers. XANES studies of fission product speciation in low-level radioactive cementitious wasteforms. Migration '93 Conference. Charleston, SC. December 1993.

Clark, S. B. and G. R. Choppin. Ligand exchange kinetics as a probe to determine the rate of rare earth interactions with size fractionated humic acid. Migration '93 Conference. Charleston, SC. December 1993.

Clark, S. B. Modeling the factors affecting cadmium binding to dissolved organic matter. American Chemical Society National Meeting. San Diego, CA. March 1994.

Clark, S. B., A. T. Buchanan, T. G. Hinton, and M. Malek. Separation and determination of isotopes of strontium in calcium carbonate matrices. 3rd International Conference on Methods and Applications of Radioanalytical Chemistry. Kona, HI. April 1994.

Clark, S. B. Invited Speaker. The kinetics of metal interactions with humic materials. University of Cincinnati. Cincinnati, OH. May 1994.

Clark, S. B. Invited Speaker. Applications of x-ray absorption spectroscopy to environmental problems at the Savannah River Site. Florida State University. Gainesville, FL. May 1994.

Collins, B., T. E. Hickox, and B. Collins. Regeneration in an old growth bottomland hardwood forest. Association of Southeastern Biologists. Orlando, FL. April 1994.

Collins, B. Seedback composition of a constructed wetland. Association of Southeastern Biologists. Orlando, FL. April 1994.

Congdon, J. D. Life history evolution and longevity. Victor Valley College. Victorville, CA. October 1993.

Congdon, J. D. Invited Speaker. Parental investment strategies in reptiles. Second World Congress of Herpetology. Adelaide, Australia. December 1993.

Congdon, J. D. Evolution of life history of long-lived organisms. Southwestern Texas State University. San Marcos, TX. February 1994.

Congdon, I. D. Evolution of life history of long-lived organisms. University of Texas. Arlington, TX. February 1994.

Congdon, J. D. Analysis life history, the problem of evolving longevity. University of Tennessee. Knoxville, TN. February 1994.

Congdon, J. D., A. E. Dunham, R. C. Van Loben Sels. Invited Speaker. Demographics of long-lived organisms: Implication for conservation and management. Desert Tortoise Society. Tucson, AZ. March 1994. 
Congdon, J. D. Implications of individual variation for demographics of painted turtles. Joint meeting of the Herpetologists' League and the Society for the Study of Amphibians and Reptiles. Athens, GA. July 1994.

Congdon, J. D., R. U. Fischer, and C. J. Salice. Life history characteristics and metal contamination in the turtle, Trachemys scripta, from a coal ash basin. Joint meeting of the Herpetologists' League and the Society for the Study of Amphibians and Reptiles. Athens, GA. July 1994.

Congdon, J. D. and D. H. Gist. Onset of copulatory activities in turtles. Joint meeting of the Herpetologists' League and the Society for the Study of Amphibians and Reptiles. Athens, GA. July 1994.

Consolie, P. A. and R. A. Kennamer. Sources of nest failure and success rates in a population of boxnesting wood ducks. 122th Meeting of the American Ornithologists' Union. Missoula, MT. June 1994.

Dietsch, B. M., H. G. Hanlin, J. P. McLendon, and L. D. Wike. Lost Lake --- Restoration of a Carolina Bay. 21 st Annual Conference on Wetlands Restoration and Creation. Hillsborough Community College. Tampa, FL. May 1994.

Dietsch, B. M., H. G. Hanlin, J. P. McLendon, and L. D. Wike. Reptile and amphibian recolonization of a restored Carolina Bay. 15th Annual Meeting of the Society of Wetland Scientists. Portland, OR. June 1994.

Dixon, P. M. Invited Speaker. Living in a fluctuating environment: Water levels, climate change, and amphibian population dynamics in temporary wetlands. University of Tennessee. Knoxville, TN. October 1993.

Dixon, P. M. Invited Speaker. Estimating maximum responses in some ecological data sets. University of South Carolina. Columbia, SC. December 1993.

Dixon, P. M. and S. Heppell. Elasticity analysis in deterministic and stochastic matrix models. Southeastern Mathematical and Statistical Ecology Group. Raleigh, NC. April 1994.

Dorcas, M. E., C. R. Peterson, R. D. Nagle, T. D. Tuberville, T. K. Lynch, J. D. Congdon, and J. W. Gibbons. Monitoring anuran vocalizations at the Savannah River Site using automated recording systems. Joint meeting of the Herpetologists' League and the Society for the Study of Reptiles and Amphibians. Athens, GA. July 1994.

Dosskey, M. G. and P. M. Bertsch. Modified elemental transport in groundwater passing through forested riparian wetlands in South Carolina. Soil Science Society of America Annual Meeting. Cincinnati, OH. November 1993.

Edwards, A. L. and R. W. Wyall. Population genetics of the rare Asclepias texana and its widespread congenor, A. perrenis. Ecological Society of America Annual Meeting. Madison, WI. August 1993.

Edwards, A. L. Flow cytometric assessment of DNA alterations in largemouth bass: Comparison with parameters of the health assessment index. Hilton Head, SC. February 1994.

Fischer, R. U. Invited Speaker. Response of bluegill to 30 years of thermal extremes: A case of rapid evolution? Eastern Illinois University. Charleston, IL. February 1994.

Fischer, R. U. Invited Speaker. Response of bluegill to 30 years of thermal extremes: A case of rapid evolution? Berry College. Mt. Berry, GA. March 1994. 
Fisher, S. K., C. E. Dallas, C. H. Jagoe, R. K. Chesser, and M. H. Smith. Seasonality and taxonomy of epizoic diatoms on planktonic cladocerans in three Iowa lakes. Ecological Society of America Annual Meeting. Madison, WI. August 1993.

Fisher, S. K., C. H. Jagoe, and C. Dallas. Approaches to detect potential genotoxic effects in wild organisms inhabiting contaminated environments. Society of Environmental Toxicology and Chemistry Annual Meeting. Houston, TX. November 1993.

Fisher, S. K., C. E. Dallas, C. H. Jagoe, R. K. Chesser, and M. H. Smith. Variation in blood cell DNA content in fish from Chernobyl-contaminated ponds in Ukraine. 14th Annual Meeting of the Society of Environmental Toxicology and Chemistry. Houston, TX. November 1993.

Fletcher, D., D. Wilkins, and R. Paul. Experimental evidence of host-specific costs from nest association with dusky shiners. American Society of Ichthyologists and Herpetologists. Los Angeles, CA. June 1994.

Fore, M. and D. E. Scott. Dietary effects on growth, lipid levels, and reproduction in the marbled salamander. Society for the Study of Amphibians and Reptiles Annual Meeting. Bloomington, IN. August 1993.

Frazer, N. B. Growth of loggerhead sea turtles in Australian waters. Sea Turtle Symposium Annual Meeting. Hilton Head, SC. March 1994.

Garrett, K. A. The spatial pattern and area of influence of a plant competitor: A model of their impact on plant populations. Ecological Society of America Annual Meeting. Madison, WI. August 1993.

Gibbons, J. W. Invited Speaker. Keeping all the pieces. Smithsonian Associate Residents Program. Washington, DC. August 1993.

Gibbons, J. W. Invited Speaker. Reptiles and amphibians of the South Carolina coast: Part of our southern heritage. South Carolina Marine Educator's Annual Conference. Seabrook Island, SC. October 1993.

Gibbons, J. W. Invited Speaker. Long-term research on long-lived turtles. Lessons from life in the slow lane. Mississippi State University. Jackson, MS. October 1993.

Gibbons, J. W. Invited Speaker. Long-term research with long-lived turtles. Lessons from life in the slow lane. Archibold Biological Station. Lake Placid, FL. November 1993.

Gibbons, J. W. Invited Speaker. Long-term research with long-lived turtles: What can we learn from life in the slow lane? Auburn University. Auburn, AL. November 1993.

Gibbons, J. W. Invited Speaker. Biodiversity of South Carolina: Our natural heritage. South Carolina Academy of Science. Hartsville, SC. November 1993.

Gibbons, J. W. Invited Speaker. Long-term research with reptiles. East Carolina University. Greenville, NC. February 1994.

Gibbons, J. W. Keeping all the pieces. American Society for Quality Control Annual Eastern Energy Environmental Quality Conference. Durham, NC. March 1994.

Gibbons, J. W. Invited Speaker. Research with Turtles. Purdue University. Lafayette, IN. March 1994.

Gibbons, J. W. Long-term research with reptiles. American Society for Quality Control 22nd Annual Meeting. Charlotte, NC. March 1994. 
Gibbons, J. W. Turtle ecology. Drexel University. Philadelphia, PA. April 1994.

Gibbons, J. W. Keeping all the pieces. Chautauqua Literary \& Scientific Circle. Chautauqua, NY. July 1994.

Gubista, K. R. Genetic variation of peromyscus populations during a population decline. Southeast Population Ecology and Ecological Genetics Group Meeting. Camp Sertoma, NC. October 1993.

Gubista, K. R. Peromyscus population decline: Measures of genetic variation. Annual Meeting of the Society for the Study of Evolution. Athens, GA. June 1994.

Gubista, K. R. Peromyscus population decline: Measures of genetic variation. American Society of Mammalogists. Washington, DC. June 1994.

Herbert, B. E. and G. L. Mills. Water extractable lipids in soils. Annual Meeting of the Soil Science Society of America. Cincinnati, OH. November 1993.

Hernandez, D., P. Johns, J. Novak, and M. H. Smith. Evidence for the occurrence of strong genetic differentiation of eastern mosquitofish in the Altamaha drainage in Georgia. American Society of Ichthyologists and Herpetologists. Los Angeles, CA. June 1994.

Hicks, K. M., D. L. Pyer, M. E. Mulvey, C. Lydeard, and G. M. Davis. Invited Speaker. Genetic analysis of freshwater mussels. Department of the Interior. Leetown, WV. May 1994.

Hicks, K. M. and M. E. Mulvey. Species survey of South Carolina unionids, with emphasis on Elliptio. American Malacological Union meeting. Houston, TX. July 1994.

Hinton, T. G. Invited Speaker. Results of Chernobyl experiments on foliar absorption of radionuclides. Paul Scherrer Institute. Villigen, Switzerland. August 1993.

Hinton, T. G. Invited Speaker. Anomalies in soil mass loading estimates. CEC Working Group on Transfer of Radionuclides to Domestic Animals. Nottingham, UK. September 1993.

Hinton, T. G. Invited Speaker. Foliar absorption of resuspended contaminants. CEC Working Group on Soil to Plant Transfer of Radionuclides. Gomel, Belyruss. September 1993.

Hinton, T. G. Invited Speaker. Fundamentals of radioecology. Savannah River Ecology Laboratory. Aiken, SC. October 1993.

Hinton, T. G. The principles of radioecology: Studying the fate and effects of radioactive contaminants in the environment. Society for Environmental Toxicology and Chemistry Annual Meeting. Houston, TX. November 1993.

Hinton, T. G. and F. W. Whicker. A screening model approach to estimate the probability of harmful effects to fish from radionuclide exposures at the Savannah River Site. Commission of European Communities. Lisbon, Portugal. March 1994.

Hooker, K. and V. Rogers. Erosion: Unregulated menace to wetlands. 21st Annual Conference on Wetlands Restoration and Creation. Hillsborough Community College. Tampa, FL. May 1994.

Hooker, K. and V. Rogers. Investigation into a case of tree stress and death in a wetland. 21st Annual Conference on Wetlands Restoration and Creation. Hillsborough Community College, Tampa, FL. May 1994. 
Hunter, D. B. Invited Speaker. Applications of XAFS spectroscopy to the environmental sciences: Pitfalls and rewards. Notre Dame University. Southbend, IN. August 1993.

Hunter, D. B. and P. M. Bertsch. Aluminum interactions with the cellulosic component of plant cell walls. Third International Symposium of Plant-Soil Interactions at Low pH. Brisbane, Australia. September 1993.

Hunter, D. B. and P. M. Bertsch. Application of 26-aluminum tracer studies to environmental chemistry of aluminum. Third International Symposium of Plant-Soil Interactions at Low pH. Brisbane, Australia. September 1993.

Hunter, D. B. and P. M. Bertsch. An overview of accelerator mass spectrometry in aluminum tracer studies. Third International Symposium of Plant-Soil Interactions at Low pH. Brisbane, Australia. September 1993.

Hunter, D. B. Invited Speaker. Development of new methodologies in spectroscopy to study the physicochemical behavior of metal contaminants in the environment. Alligator Rivers Region Research Institute. Jabiru, NT, Australia. September 1993.

Hunter, D. B. Invited Speaker. The role of scientific research in political decision making in environmental issues. Office of the Supervising Scientist. Darwin, NT, Australia. September 1993.

Hunter, D. B. Invited Speaker. Applications of advanced spectroscopic methods to solving complex environmental problems. Naval Research Laboratory. Washington, DC. May 1994.

Imm, D. W. and K. W. McLeod. Model predictability of composition of an upper coastal plain hardwood slope. Botanical Society of America Annual Meeting. Des Moines, IA. August 1993.

Imm, D. W. Scalar dependence of species-environment relations. Association of Southeastern Biologists. Orlando, FL. August 1993.

Jagoe, C. H. and D. A. Welter. Ultrastructure of the nuclei of fish red blood cells - Comparisons within and among species. American Fisheries Society 123rd Annual Meeting. Portland, OR. September 1993.

Jagoe, C., C. Dallas, R. Chesser, M. Smith, and S. Fisher. Assessment of genetic damage as a biomarker in the remediation contaminated or polluted sites. ER93 Environmental Remediation Conference. Augusta, GA. October 1993.

Jagoe, C. H., R. K. Chesser, M. H. Smith, C. Dallas, S. K. Fisher, and M. Lomakin. Distribution of radionuclides and other contaminants in ponds near Chernobyl, Ukraine. Society of Environmental Toxicology and Chemistry 14th Annual Meeting. Houston, TX. November 1993.

Jagoe, C. H. Invited Speaker. Responses and effects at the tissue level - Quantitative methods in histopathology applied to ecotoxicology. Savannah River Symposia on Environmental Science. Quantitative Ecotoxicology: A Hierarchical Approach. Aiken, SC. June 1994.

Jagoe, C. H., B. Grasman, and T. Youngblood. Studies of the effects of drawdown of a reservoir on mercury levels in fish and other organisms. Conference on Mercury as a Global Pollutant. Whistler, British Columbia. July 1994.

Jagoe, R. E. and M. C. Newman. Allele frequency shifts in field populations indicated pollutant-associated selection: Conditional verification at the PGI-2 locus of mosquitofish. Society of Environmental Toxicology and Chemistry 14th Annual Meeting. Houston, TX. November 1993. 
Jung, R. and C. Jagoe. Effects of $\mathrm{pH}$ and aluminum on green treefrog (Hyla cineria) tadpoles. 2nd World Congress of Herpetology. Adelaide, South Australia. December 1993.

Kaplan, D. I., P. M. Bertsch, and D. C. Adriano. Chemical processes responsible for the enhanced transport of metals through an acidified aquifer. Soil Science Society of America Annual Meeting. Cincinnati, OH. November 1993.

Kaplan, D. I., D. C. Adriano, P. M. Bertsch, and K. Orlandini. Mechanisms responsible for enhanced transport of actinides through a coastal plain aquifer. Migration '93 Conference. Charleston, SC. December 1993.

Kandl, K. A. Effects of acute salinity stress on inbred mosquitofish. Southeastern Population Ecology and Ecological Genetics Group Meeting. Camp Sertoma, NC. October 1993.

Kennamer, R. A. and G. R. Hepp. Factors leading to seasonal declines in clutch size and egg mass in a population of breeding wood ducks. 122th Meeting of the American Ornithologists' Union. Missoula, MT. June 1994.

Koetsier, P., G. W. Minshall, and C. T. Robinson. Macroinvertebrate benthic and drift patterns from six streams differing in chemical richness. North American Benthological Society. Orlando, FL. May 1994.

Komoroski, M. J. and R. D. Nagle. Eggs lipid variation among three species of southeastern frogs. Society for the Study of Amphibians and Reptiles Annual Meeting. Bloomington, IN. August 1993.

Krenz, J. D. and D. E. Scott. Bioenergetics of the marbled salamander: Reproductive females. Society for the Study of Amphibians and Reptiles Annual Meeting. Bloomington, IN. August 1993.

Krenz, J. D. and D. M. Sever. Mating and oviposition in paedomorphic Ambystoma talpoideum precedes the arrival of terrestrial males. Joint meeting of the Herpetologists' League and the Society for the Study of Amphibians and Reptiles. Athens, GA. July 1994.

Lee, J. R. Winter behavior of semiaquatic snakes in an outdoor enclosure. Joint meeting of the Herpetologists' League and the Society for the Study of Amphibians and Reptiles. Athens, GA. July 1994.

Lee, J. R., M. S. Mills, and J. W. Gibbons. Design and use of a semi-natural enclosure for the study of snakes. Joint meeting of the Herpetologists' League and the Society for the Study of Amphibians and Reptiles. Athens, GA. July 1994.

Leeper, D. A. and B. E. Taylor. Benthos abundance, biomass and production in a Carolina Bay wetland. North American Benthological Society. Orlando, FL. May 1994.

Leff, L. G. Invited Speaker. Molecular ecology: New approaches to old questions. Savannah River Ecology Laboratory. Aiken, SC. October 1993.

Lide, R. F. Water level fluctuations in Carolina Bay ponds. Southeastern Division of the Association of American Geographers Annual Meeting. Greensboro, NC. November 1993.

Lynch, T. K., L. D. Houck, and D. E. Scott. Male-male courtship in the marbled salamander. Joint meeting of the Herpetologists' League and the Society for the Study of Reptiles and Amphibians. Athens, GA. July 1994.

McArthur, J V. Invited Speaker. Basins to bacterial genes: Linkage between terrestrial and aquatic ecosystems. Austin College. Sherman, TX. October 1993. 
McArthur, J V. Invited Speaker. Basins to bacterial genes: Linkage between aquatic and terrestrial ecosystems. Idaho State University. Pocatello, ID. December 1993.

McArthur, J V. Invited Speaker. Bacterial genes and other things that really matter in aquatic ecosystems. University of Alabama. Tuscaloosa, AL. February 1994.

McArthur, J V. Invited Speaker. Bacterial population genetics: Basins to bacterial genes. University of Texas. Austin, TX. April 1994.

McArthur, J V., M. Plagwitz, M. Wise, J. R. Dana, L. G. Leff, and L. J. Shimkets. Bacterial genes and other things that really matter in aquatic ecosystems. North American Benthological Society. Orlando, FL. May 1994.

McArthur, J V. Bacterial genes and other things that really matter in stream ecosystems. St. Cloud State University. St. Cloud, MN. May 1994.

McCarron, J. K., H. S. Neufeld, and K. W. McLeod. Seasonal water relations and gas exchange patterns of bald and pond cypress saplings under varying soil water conditions. Association of Southeastern Biologists. Orlando, FL. April 1994.

McCloskey, J. T. and M. C. Newman. Spatial distribution of Asiatic clam (Corbicula fluminea) populations as a sublethal indicator of sediment metal contamination. Society of Environmental Toxicology and Chemistry 14th Annual Meeting. Houston, TX. November 1993.

McCreedy, C. D., R. A. Kennamer, and I. L. Brisbin, Jr. Radiocesium $\left({ }^{137} \mathrm{Cs}\right)$ in mourning doves using a contaminated lakebed exposed by drawdown. 122nd Meeting of the American Ornithologists' Union. Missoula, MT. June 1994.

McLeod, K. W., J. K. McCarron, and W. H. Conner. Inundation and salinity stress of wetland woody species. American Institute of Biological Sciences and Botanical Society of America Annual Meeting. Ames, IA. August 1993.

McLeod, K. W., G. R. Wein, and R. R. Sharitz. Wetland restoration for habitat reconstruction and contaminant stabilization. ER93 Environmental Remediation Conference. Augusta, GA. October 1993.

McLeod, K. W., J. K. McCarron, and H. S. Neufeld. Comparative growth patterns of bald and pond cypress saplings under varying soil water conditions. Association of Southeastern Biologists. Orlando, FL. April 1994.

McLeod, K. W. Innovative restoration techniques. Association of Southeastern BiologistsAnnual Meeting. Orlando, FL. April 1994.

McLeod, K. W. The importance of fire in sandhills diversity. Association of Southeastern Biologists. Orlando, FL. April 1994.

McLeod, K. W., M. R. Reed, and T. G. Ciravolo. Selection of woody species for bottomland restoration. 21 st Annual Conference on Wetlands Restoration and Creation. Hillsborough Community College. Tampa, FL. May 1994.

Meffe, G. K. Invited Speaker. Genetic and evolutionary perspectives on biodiversity conservation. Wisconsin Department of Natural Resources, Bureau of Research Statewide Meeting. Wisconsin Delles, WI. September 1993.

Meffe, G. K. Invited Speaker. Aquatic Ecosystems. Bureau of Land Management, National Training Course on Biodiversity. Phoenix, AZ. December 1993. 
Meffe, G. K. Population and environment... Why do we care? "Population Equation: Environment, Families and the Future" Conference. Columbia, SC. May 1994.

Meffe, G. K. Why care about endangered species? Georgia Southwestern College Earth Day. Americus, GA. May 1994.

Messier, A. N. and M. C. Newman. Estimating sample size during biomonitoring: when is enough enough? Society of Environmental Toxicology and Chemistry 14th Annual Meeting. Houston, TX. November 1993.

Miller, W. P., J. C. Seaman, D. E. Radcliffe, and P. M. Bertsch. Ion transport and solute breakthrough in a variable charge system. Soil Science Society of America Annual Meeting. Cincinnati, OH. November 1993.

Mills, G. L. Invited Speaker. Applications of organic molecular markers in biogeochemistry and environmental chemistry. Virginia Polytechnic Institute and State University. Blacksburg, VA. November 1993.

Mills, G. L. Invited Speaker. Research programs in environmental chemistry at the Savannah River Ecology Laboratory. Claflin College. Orangeburg, SC. February 1994.

Mills, M. S. and C. J. Hudson. Population ecology of Nerodia taxispilota on the Savannah River Site, USA. Second World Congress of Herpetology. Adelaide, Australia. December 1993.

Mills, M. S., C. J. Hudson, and H. J. Berna. Foraging ecology of the brown water snake on the Savannah River Site, South Carolina, USA. Joint meeting of the Herpetologists' League and the Society for the Study of Reptiles and Amphibians. Athens, GA. July 1994.

Mulvey, M. E. and M. C. Newman. Genetic and demographic responses of mosquitofish populations exposed to mercury. South Eastern Population Ecology and Genetics Group Annual Meeting. Camp Sertoma, NC. October 1993.

Mulvey, M. E. and D. L. Pyer. Relationships among unionacean mussels assessed with mitochondrial DNA sequence variation. American Malacological Union. Houston, TX. July 1994.

Newman, M. C., M. M. Keklak, and S. M. Doggett. Quantifying animal size effects on toxicity: A general approach. Society of Environmental Toxicology and Chemistry 14th Annual Meeting. Houston, TX. November 1993.

Newman, M. C. Quantitative ecotoxicology of metals in aquatic systems. USEPA and Ministry of Environment of Israel. Haifa, Israel. May 1994.

Newman, M. C. Invited Speaker. Ecotoxicology as a science. Savannah River Symposia on Environmental Science. Quantitative Ecotoxicology: A Hierarchical Approach. Aiken, SC. June 1994.

Newman, M. C. Invited Speaker. Ecologically meaningful estimates of lethal effect. Savannah River Symposia on Environmental Science. Quantitative Ecotoxicology: A Hierarchical Approach. Aiken, SC. June 1994.

Niewiarowski, P. and A. E. Dunham. Physiologically structured, individual based models, genetic algorithms and tradeoffs between offspring size and number in sceloporine lizards. Joint meeting of the Herpetologists' League and the Society for the Study of Amphibians and Reptiles. Athens, GA. July 1994. 
Niquette, D. J., F. W. Whicker, and T. G. Hinton. The effects of changes in conductivity and cation concentration on the accumulation of ${ }^{137} \mathrm{Cs}$ in largemouth bass (Micropterus salmoides). Migration '93 Conference. Charleston, SC. December 1993.

Novak, J. M. The path(s) to asymmetry. Southeastern Population Ecology and Ecological Genetics Group Annual Meeting. Camp Sertoma, NC. October 1993.

Nuenberg, N. J., J. C. Seaman, M. E. Sumner, and W. P. Miller. Effect of phosphate, liming and gypsum on cation leaching through packed columns. American Society of Agronomy Annual Meeting. Cincinnati, OH. November 1993.

Onken, B. M., G. L. Mills, and J. E. O'Neill. Soil-lipid characterization by thin-layer chromatography/flame-ionization detection. Soil Science of America Annual Meeting. Cincinnati, OH. November 1993.

Parrish, V. H., K. W. McLeod, M. R. Reed, and T. G. Ciravolo. Restoration methods of inundated bottomlands. 21st Annual Conference on Wetlands Restoration and Creation. Hillsborough Community College. Tampa, FL. May 1994.

Pauley, E. F., S. C. Nodvin, T. B. Coffey, A. K. Rose, and N. S. Nichols. Vegetation, biomass, and nitrogen pools in a Great Smoky Mountains spruce-fir forest. Association of Southeastern Biologists Annual Meeting. Orlando, FL. April 1994.

Pechmann, J. H. Complex life cycles: Aquatic and terrestrial density-dependence in the mole salamander. Ecological Society of America Annual Meeting. Madison, WI. August 1993.

Pechman, J. H. Population regulation in complex life cycles: Aquatic and terrestrial density-dependence in the narrow-mouthed toad. Joint meeting of the Herpetologists' League and the Society for the Study of Amphibians and Reptiles. Athens, GA. July 1994.

Peters, E. L. Invited Speaker. Radioecological research at the U.S. Department of Energy's Savannah River Site. Kiev University. Kiev, Ukraine. September 1993.

Peters, E. L. and I. L. Brisbin, Jr. Invited Speaker. ${ }^{137} \mathrm{Cs}$ and ${ }^{90} \mathrm{Sr}$ uptake in the yellow-bellied turtle (Trachemys scripta). Environmental influences on the radionuclide kinetics of an ectotherm. International Conference on Nuclear Methods in the Environment. Kiev, Ukraine. September 1993.

Pyer, D. L., K. M. Hicks, M. E. Mulvey, C. Lydeard, and G. M. Davis. Invited Speaker. Genetic analysis of freshwater mussels. U.S. Department of the Interior. Leetown, WV. May 1994.

Pyer, D. L. and M. E. Mulvey. Genetic analysis of freshwater mussels: Genera Amblema and Megalonaias. American Malacological Union. Houston, TX. July 1994.

Reed, M. R. and K. W. McLeod. Planting unconsolidated sediment with flood tolerant species. Association of Southeastern Biologists Annual Meeting. Orlando, FL. April 1994.

Reed, M. R. and K. W. McLeod. Planting unconsolidated sediment with flood tolerance species. 21st Annual Conference on Wetlands Restoration and Creation. Hillsborough Community College. Tampa, FL. May 1994.

Rhodes, O. E. and R. S. Johns. Invited Speaker. Relationships between heterozygosity and conception date in white-tailed deer from South Carolina. International Union of Game Biologists XXI Congress. Halifax, Nova Scotia, Canada. August 1993. 
Rhodes, O. E., D. J. Buford, M. S. Miller, and R. S. Lutz. Genetic structure of reintroduced Rio Grande wild turkeys in Kansas. 122nd Meeting of the American Ornithologists' Union. Missoula, MT. June 1994.

Ritchie, $\mathrm{K}$. The structure of bacterial communities associated with Caribbean corals. Third Congress on Marine Science. Havana, Cuba. February 1994.

Ritchie, K. A molecular systematics approach to the evolution of trophic diversity among the middle American cichlid fish genus cichlasoma (Amphilophus). South Carolina Academy of Science, University of South Carolina. Aiken, SC. April 1994.

Scott, D. E. and L. Houck. Seasonal changes in hormone levels in male Ambystoma opacum. Society for the Study of Amphibians and Reptiles Annual Meeting. Bloomington, IN. August 1993.

Seaman, J. C., P. M. Bertsch, and W. P. Miller. The influence of solution chemistry and flow rate on the generation and transport of colloids. Soil Science Society of America Annual Meeting. Cincinnati, OH. November 1993.

Seel, J. F., W. F. Whicker, and D. C. Adriano. The effects of potassium on the availability of ${ }^{137} \mathrm{Cs}$ in vegetables grown on a contaminated lake-bed. Migration '93 Conference. Charleston, SC. December 1993.

Seel, J. F., I. L. Brisbin, Jr., and M. Benner. Cesium-137 uptake in white-tail deer muscle and liver from a contaminated lake-bed. Society of Environmental Toxicology and Chemistry Annual Meeting. Durham, NC. May 1994.

Sharitz, R. R. and M. R. Vaitkus. Spatial patterns of disturbance and recovery from hurricane winds in an old-growth floodplain forest in the southeastern USA. International Botanical Congress. Yokohama, Japan. August 1993.

Sharitz, R. R. Invited Speaker. Effects of coarse woody debris on seedling recruitment in southeastern forests. U.S. Forest Service Workshop. Athens, GA. October 1993.

Siemering, G. S., S. M. Serkiz, S. B. Clark, and R. M. Kriegel. Modeling the factors affecting cadmium binding to dissolved organic matter. 207th American Chemical Society Annual Meeting. San Diego, CA. March 1994.

Simon, L., H. W. Martin, and D. C. Adriano. Cadmium effects on soil pollution index plants chicory and dandelion. American Society of Agronomy Annual Meeting. Cincinnati, OH. November 1993.

Smith, M. H. Genetic variability and reproduction in cervids. International Union of Game Biologists XXI Congress. Halifax, Nova Scotia, Canada. August 1993.

Smith, M. H., P. Johns, and J. M. Novak. Importance of genetic perspectives in management plans for the next century. Southeast Deer Study Group 17th Annual Meeting. Charlottesville, VA. February 1994.

Stankus, P. T. and G. R. Wein. Hydrologic effects on species diversity and productivity: A mesocosm approach. Association of Southeastern Biologists Annual Meeting. Orlando, FL. April 1994.

Stankus, P. T. and G. R. Wein. Hydrologic effects on species diversity and productivity: A mesocosm approach. Society of Wetland Scientists Annual Meeting. Portland, OR. June 1994.

Stephens, W. L. and R. A. Kennamer. Variations in egg size of common moor hens. 122nd Meeting of the American Ornithologists' Union. Missoula, MT. June 1994. 
Sugg, D. W. Invited Speaker. Breeding structures and effective population size. University of Illinois. Champaign, IL. January 1994.

Sugg, D. W. and R. K. Chesser. Assessment of geographic patterns for morphometric traits. Southwestern Association of Naturalists Annual Meeting. Emporia, KS. April 1994.

Taylor, B. E. Holocene changes in Carolina bays. Institute of Ecology, University of Georgia. Athens, GA. September 1993.

Taylor, B. E. and D. E. Scott. The effect of larval dependence on population dynamics of marbled salamanders. Joint meeting of the Herpetologists' League and the Society for the Study of Amphibians and Reptiles. Athens, GA. July 1994.

Tuberville, T. D. and V. J. Burke. Do flag marker attract turtle nest predators? Association of Southeastern Biologists Annual Meeting. Orlando, FL. June 1994.

Tuberville, T. D. and V. J. Burke. Do flag markers attract turtle nest predators? Joint meeting of the Herpetologists' League and the Society for the Study of Reptiles and Amphibians. Athens, GA. July 1994.

Ver Velde, S. K., S. H. Colwell, and R. A. Kennamer. Composition of wood duck eggs in relation to egg size, clutch size, laying sequence and skipped days of laying. 122nd Meeting of the American Ornithologists' Union. Missoula, MT. June 1994.

Vitt, L., J. D. Congdon, and J. W. Gibbons. Invited Speaker. Parental investment by turtles. Second International Congress of Herpetology. Adelaide, Australia. January 1994.

Weeks, S. C. Invited Speaker. Quantitative genetics and phenotypic plasticity of life-history traits in mosquitofish. University of Nevada. Reno, NB. February 1994.

Weeks, S. C. Quantitative genetics and phenotypic plasticity of life-history traits in mosquitofish (Gambusia holbrooki). Southeastern Population Ecology and Genetics Group Meeting. Camp Sertoma, NC. October 1993.

Weeks, S. C. The hidden cost of reproduction: Reduced energetic intake caused by spatial constraints in the body cavity. ASIH. Los Angeles, CA. June 1994.

Wein, G. R. and B. Collins. Seedbank composition of a constructed wetland. Association of Southeastern Biologists Annual Meeting. Orlando, FL. April 1994.

Wein, G. R. and B. Collins. Hydrologic effects on species diversity and productivity: A mesocosm approach. Association of Southeastern Biologists Annual Meeting. Orlando, FL. April 1994.

Wein, G. R. and B. S. Collins. Effect of shoreline topography on vegetation development in a planted cooling reservoir. Society of Wetland Scientists Annual Meeting. Portland, OR. June 1994.

Whicker, F. W., D. C. Adriano, and J. F. Seel. Evaluation of the potential health-risk from the ingestion of vegetables grown on an exposed ${ }^{137} \mathrm{Cs}$-contaminated lake bed. American Nuclear Society Meeting. Charleston, SC. September 1993.

Wilkins, S. D. Diel and seasonal variation of riffle inhabiting fish in Bayou Pierre, Mississippi. American Society of Ichthyologists and Herpetologists Annual Meeting. Los Angeles, CA. June 1994.

Winkelman, D. L. Tradeoffs between predation and reproduction. Ethology, Ecology, and Evolution of Fishes Annual Meeting. Victoria, British Columbia. May 1994. 
Woodward, L. A. and M. E. Mulvey. Chronic mercury exposure: Allozyme differentiation. Carolinas Regional SETAC Meeting. Durham, NC. May 1994.

Yeomans, S. R. Orientation of turtles. Society for the Study of Amphibians and Reptiles Annual Meeting. Bloomington, IN. August 1993.

Young, P. J., R. F. Lide, and R. R. Sharitz. Growth response of lobolly pine to the hydrology of a Carolina Bay. Association of Southeastern Biologists Annual Meeting. Orlando, FL. April 1994.

Young, P. J. Estimating dates of mortality of pond cypress in a Carolina Bay. International Conference on Tree Rings, Environment and Humanity: Relationships and Processes. Tucson, AZ. May 1994. 


\section{APPENDIX}


Figure 1. Organizational Chart, Savannah River Ecology Laboratory

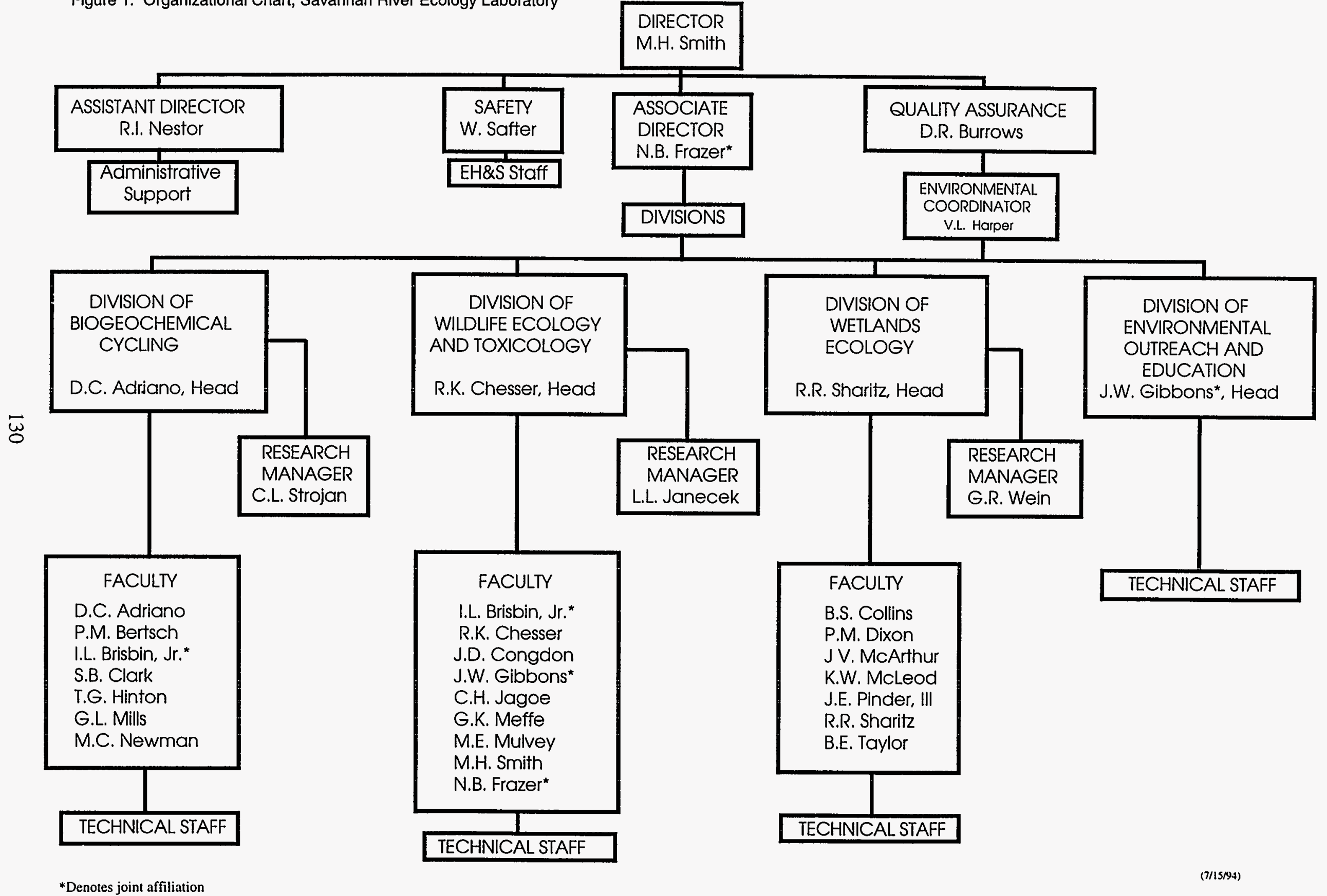

